\title{
FINANCIAL REPORTING QUALITY AND DUAL-HOLDING OF DEBT AND EQUITY
}

by

\section{Leila Peyravan}

A thesis submitted in conformity with the requirements

for the degree of Doctor of Philosophy

Joseph L. Rotman School of Management

University of Toronto

September, 2016

(C) Copyright by Leila Peyravan (2016) 


\title{
Financial Reporting Quality and Dual-Holding of Debt and Equity \\ Leila Peyravan
}

\author{
A thesis submitted in conformity with the requirements \\ for the degree of Doctor of Philosophy \\ Joseph L. Rotman School of Management \\ University of Toronto
}

September, 2016

\begin{abstract}
In this dissertation, I examine the causes and consequences of investors' simultaneous participation in a firm's syndicated loan and equity (“dual-holding”). In the first chapter, I investigate whether the financial reporting quality of a firm is associated with investors' dual-holding in that firm. Using hand-collected data on institutional investors' loan and equity holdings from 2006 to 2014, I predict and find that investors are more likely to be dual-holders in firms with low financial reporting quality. Two possible explanations of this result are: (1) investors use dual-holding as a viable channel to gain access to better information in firms with low financial reporting quality and to make profitable trades in the firm's equity based on material non-public information, thus extracting rent from other shareholders ("rent-extraction"), and (2) investors use dual-holding to mitigate the conflict of interest between shareholders and creditors that is exacerbated by the firm's low financial reporting quality (“incentive-alignment"). Consistent with the rent-extraction hypothesis, I find that dual-holders achieve risk-adjusted abnormal annualized returns of approximately $6 \%$ in the borrower's equity in the time period between the syndicate origination and the next quarterly earnings announcement. Contrary to the incentive-alignment hypothesis, I find that firms with dual-holders do not experience any improvements in their operating and market performance.
\end{abstract}


In the second chapter, I analyze the consequences of investors' dual-holding. I first examine how dual-holders influence the firm's information uncertainty and disclosure environment. Using hand-collected data on lenders that simultaneously hold equity-position in the borrower, I find that dual-holders decrease the firm's information uncertainty by causing the equity prices to adjust to firm-specific information more rapidly. Furthermore, consistent with shareholders' increased scrutiny following dual-holder participation in a firm, I find that managers of such firms are more likely to issue earnings forecast following loan origination. Taken together, My findings have important implications for investors and policymakers and shed light on the importance of weighting the overall benefits versus the costs of informed-trading to the investors and capital market by the SEC and investors before enforcing insider trading rules and scrutiny of dual-holding institutions. 


\section{ACKNOWLEDGMENTS}

I am grateful to my co-chairs Ole-Kristian Hope and Hai Lu, for their mentorship and support throughout my time at Rotman. I would also like to thank my committee members Dushyant Vyas and Scott Liao for their guidance and support. I would like to dedicate this dissertation to my parents (Maryam and Behzad), my grandmother (Mah-Monir), and to my husband Joe.

Finally, to Sophie and Max, thank you for always making me feel loved, auntie loves you to the moon and back! 


\section{TABLE OF CONTENTS}

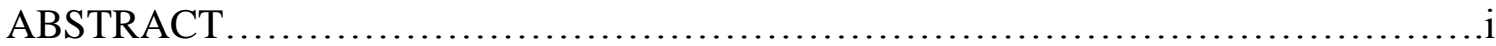

ACKNOWLEDGEMENTS.........................................................

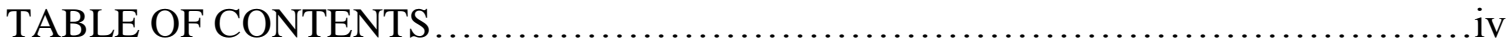

LIST OF TABLES ............................................................... vii

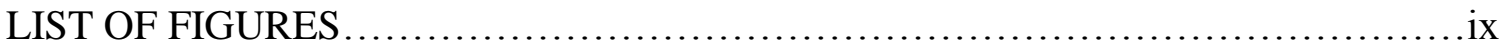

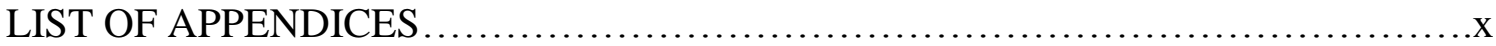

CHAPTER 1-FINANCIAL REPORTING QUALITY AD DUAL-HOLDING OF DEBT

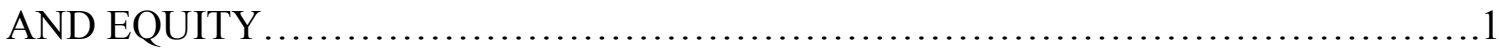

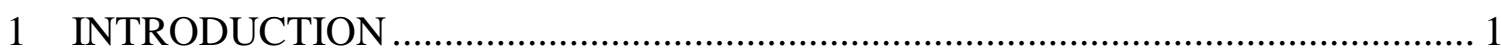

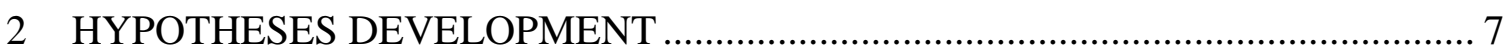

2.1 Financial Reporting Quality and Dual-Holding .................................................. 7

2.2 Investors' Incentives for Dual-Holding .......................................................... 9

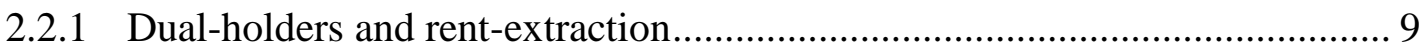

2.2.2 Dual-holders and incentive alignment between shareholders and creditors . 11

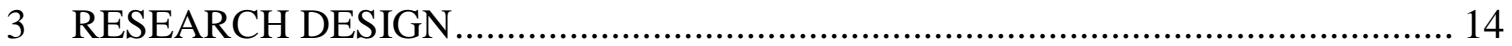

3.1 Measurement of financial reporting quality .................................................. 14

3.2 Measurement of Abnormal Returns ......................................................... 15

3.3 Dual-Holders' Influence on Loan Characteristics................................................ 17

3.4 Dual-Holders' Influence on the Firm's Operating and Market Performance ..... 19

4 DATA AND SUMMARY STATISTICS.............................................................. 20 
5.1 Financial Reporting Quality and Dual-Holding .......................................... 23

5.2 Investors' Incentives for Dual-Holding ....................................................... 26

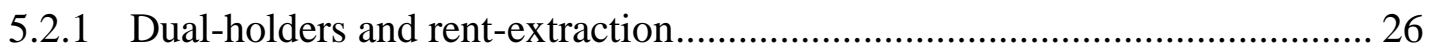

5.2.2 Dual-holders and incentive alignment between shareholders and creditors . 30

5.2.3 Dual-holders and changes in the firm's operating and market performance 31

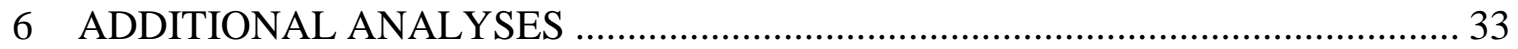

6.1 Controls for the Potential Endogeneity of Financial Reporting Quality ............ 33

6.2 Controls for the Potential Endogeneity of Dual-Holding ................................ 34

6.3 Controls for the Size of Dual-Holders' Equity and Loan Holding .................... 34

6.4 Institutional Lenders with Prior Equity Positions ...................................... 36

6.5 Institutional Lenders with Equity Positions in the Next Quarter ...................... 37

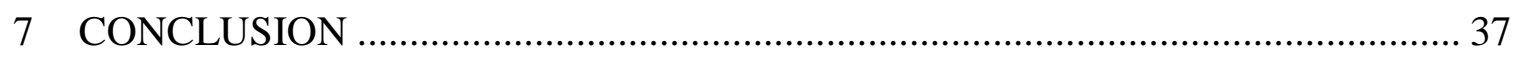

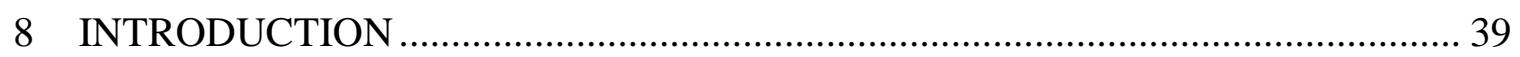

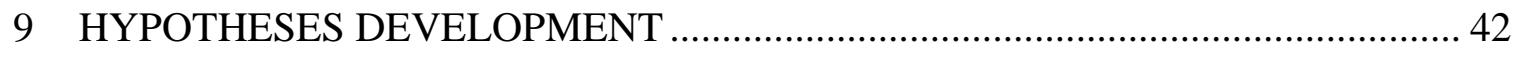

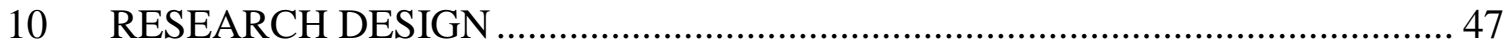

10.1.1 Measures of dual-holder participation................................................. 47

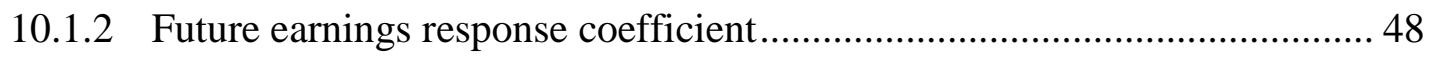

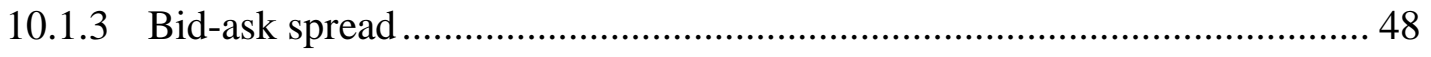

10.1.4 Cumulative abnormal returns ....................................................... 51 
11 DATA

12 EMPIRICAL ANALYSES ................................................................... 53

12.1 Dual-holders' influence on the borrowers' information uncertainty............... 53

12.2 Dual-holders' influence on the borrowers' disclosure quality ........................ 56

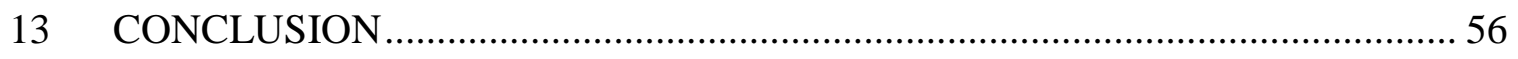




\section{LIST OF TABLES}

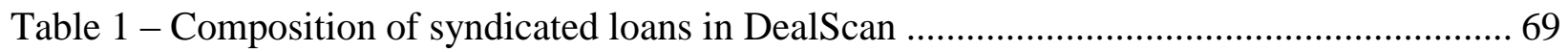

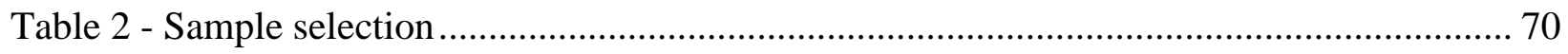

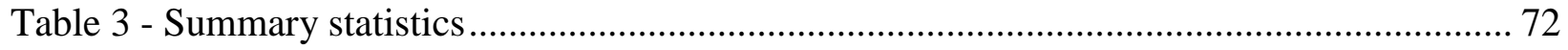

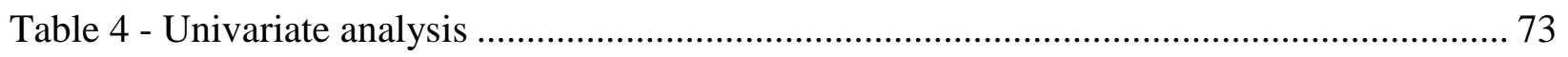

Table 5-Financial reporting quality and dual-holding ................................................. 75

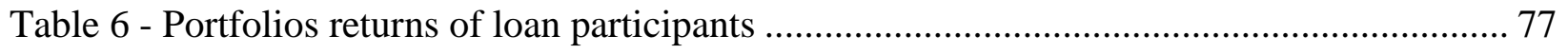

Table 7 - Portfolio returns of loan participants by accounting quality ................................... 79

Table 8 - Loan participants equity vs. loan position size ............................................... 80

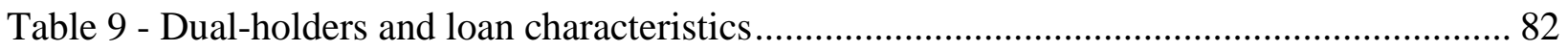

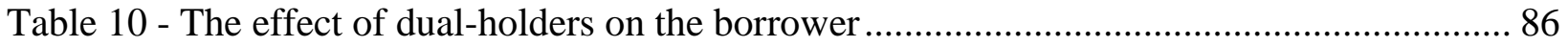

Table 11-Robustness check: IVPROBIT Regression of investors' dual-holding on financial

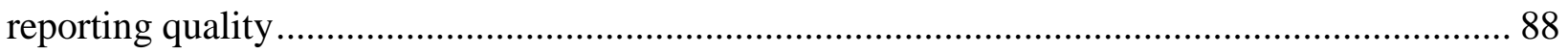

Table 12-Robustness check: 2SLS regression of the cost of the loan on dual-holding .............. 89

Table 13-Robustness check: Determinants of non-bank versus bank investors' dual-holding .... 91

.Table 14: Changes in bid-ask before and during earnings announcement ............................ 92

Table 15: Changes in illiquidity before and during earnings announcement .......................... 92

Table 16: Risk-adjusted cumulated abnormal excess returns using the Fama-French 3-factor

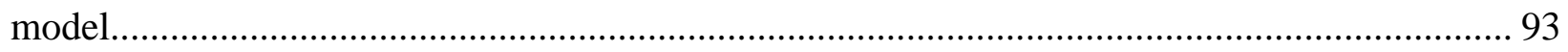

Table 17-Effect of dual-holders on the price informativeness of a firm................................. 94

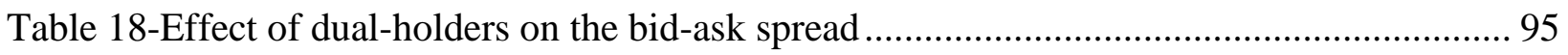

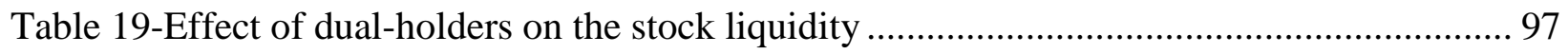

Table 20-Effect of dual-holders on the analyst forecast dispersion ..................................... 98 


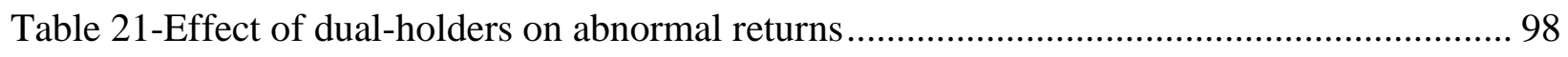

Table 22-Effect of dual-holding on the likelihood of issuance of earnings forecast ................ 101 


\section{LIST OF FIGURES}

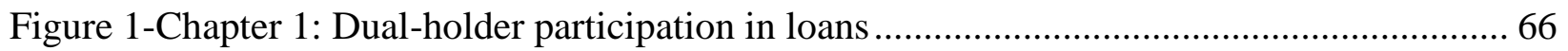

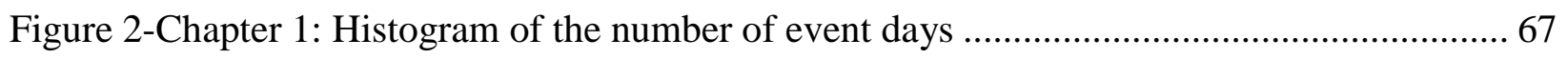

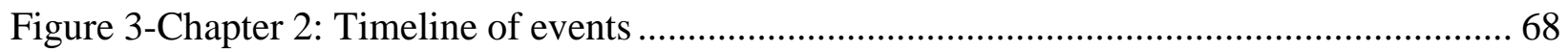




\section{LIST OF APPENDICES}

Appendix A: Chapter 1 Variable Definitions...........................................61

Appendix B: Chapter 2 Variable Definitions......................................64 


\section{Chapter 1: Financial Reporting Quality and Dual-Holding of Debt and Equity}

\section{Introduction}

Non-bank institutional investors (i.e., institutional investors that are not commercial banks such as pension funds and private-equity firms) increased their participation in the syndicated loan market from $20 \%$ of the total loan amount issued in 1990 to $60 \%$ in $2013 .{ }^{1}$ Interestingly, in over half of these loan facilities at least one institutional-investor participant per facility also held an equity position in the borrower as of the loan start date (i.e., a "dualholder"). Institutional equity-holders who are also lenders to the firm provide a unique opportunity to revisit the classic conflict of interest between shareholders and creditors and examine whether dual-holders help align the incentives of shareholders and creditors.

There is limited prior research on dual-holders. Extant studies suggest investors become dual-holders because (1) dual-holding mitigates the conflict of interest between shareholders and creditors (Jiang, Li, and Shao 2010), and (2) institutional investors are lenders of last resort and lend to higher-risk firms at a large premium (Lim, Minton, and Weisbach 2014). I add to this new and growing literature by showing that institutional equity-holders' incentive for dualholding is to gain access to a firm's material non-public information. Accordingly, dual-holding is more likely in firms with low financial reporting quality (FRQ from here on). I provide empirical evidence that dual-holders then use the firm's material non-public information to make informed trades in the borrower's equity and generate excess returns.

Shareholders' and bondholders' main source of firm-specific information is the firm's public financial reports, whereas syndicated loan participants also have access to material nonpublic information. Examples of such material non-public information include the borrower's

\footnotetext{
${ }^{1}$ I refer to non-bank institutional investors and non-bank dual-holders as "institutional investors" and "dual-holders" for brevity. I explicitly identify banking institutional investors and banking dual-holders as such.
} 
financial information and projections, covenant compliance reports, plans for any mergers or acquisitions, and collateral value appraisals. As the FRQ of a firm decreases, the information asymmetry between the firm's equity investors and syndicated-loan participants increases. Dualholding mitigates the lender-shareholder information asymmetry because dual-holders have access to information that has not been publicly disclosed by the firm. Prior studies on dualholding suggest two reasons why institutional investors might become dual-holders. Jiang, Li, and Shao (2010) find that syndicated loans with dual-holder participation have lower costs (as measured by the spread of the loan above LIBOR plus any fees) compared to loans without. The authors conclude that the lower cost of such loans is due to the incentive-alignment between shareholders and creditors that results from dual-holding. Using a different research design and a smaller sample, Lim, Minton, and Weisbach (2014) find that dual-holders do not affect the cost of a loan unless the dual-holder is a hedge fund or private-equity fund, in which case the cost of the loan is higher. The authors argue that the higher cost of such loans is because hedge funds and private-equity funds are lenders of last resort and thus charge a higher rate to lend. However, prior research has not examined the effect of a firm's FRQ and thus the quality of a firm's public information on dual-holding, even though one distinct characteristic of dual-holders is that they are shareholders with potential access to material non-public information.

I contribute to this debate by offering the novel explanation that institutional equityholders of a firm with low FRQ participate in its syndicated loans and become dual-holders in order to gain access to better information. In particular, I predict and show that institutional dualholding is more likely in firms with low FRQ because less reliable financial information enhances the dual-holders' information advantage compared to other shareholders. If dualholders make informed trades in such firms' shares based on material non-public information, 
they are more likely to generate excess returns. In other words, dual-holders could extract rent from other shareholders of the firm (Skaife, Veenman, and Wangerin 2013).

My study consists of three hypotheses. First, I predict and find that institutional equityholders attempt to gain access to better information by simultaneously participating in syndicated loans of firms with low information quality. Accordingly, firms with low FRQ are more likely to have dual-holders. I measure a firm's FRQ using commonly used measures of accruals quality (Dechow and Dichev 2002; Stubben 2010; Kothari, Leone, and Wasley 2005). ${ }^{2}$ To identify institutional investors that are lenders, I manually match each lender that appears in the DealScan database in my sample period from 2006 to 2014 to institutional investors' fund names (as they appear in funds' $13 \mathrm{f}$ filings in the Thomson-Reuters database) using $10 \mathrm{~K}$ filings and Bloomberg searches. Using this hand-collected data, I am able to identify 445 unique funds that correspond to 1,271 unique lenders in the DealScan database. Out of these 445 funds, 213 funds are dualholders, 75 of which are owned by institutional investors (non-commercial banks). I use probit regressions at the loan-level with the probability of dual-holding as the dependent variable and the accruals quality of the firm as the main test variable. The analyses also include controls for firm and loan characteristics (e.g., firm and loan riskiness and the purpose of the loan), as well as industry and year fixed effects. In all specifications, I find that FRQ is a statistically and economically significant determinant of the likelihood of dual-holding. In particular, I find that a firm with low FRQ is more likely to have dual-holders.

As an additional test, I also examine whether FRQ is associated with the likelihood of commercial banking institutions' dual-holding. Bank dual-holders are different from other institutional dual-holders in that they are less likely to depend on dual-holding to access a firm's

\footnotetext{
${ }^{2}$ In robustness checks, I also use other measures of a firm's information quality, namely analyst forecast disagreement and number of managers' forecasts.
} 
material non-public information for the following reasons. First, banking institutions are primarily relationship lenders and are interested in generating fees not only from loans, but also from cross-selling activities and monitoring of the loan (Fang, Ivashina, and Lerner 2013). Second, a large portion of commercial banks' equity holdings is held in fiduciary capacity such as in trust accounts. Third, banks are likely to already have private information about a firm from prior lending relations (e.g., screening, lending, and monitoring) with the firm (James 1987; James and Wier 1990). ${ }^{3}$ Consequently, a firm's FRQ is not likely to influence a banking institution's dual-holding in that firm. I predict that if access to better information is the primary incentive of institutional investors' dual-holding, then I should not find a significant relation between a borrower's FRQ and the likelihood of bank dual-holding. I repeat the analyses using the probability of bank dual-holding as the dependent variable and find that, as expected, the FRQ of a borrower does not affect the likelihood of dual-holding of banking institutions.

Next, I explore how dual-holders utilize their unique position and their access to material non-public information. Dual-holders can benefit from their position by (1) making informed trades based on material non-public information to gain additional profits, or (2) aligning the incentives of shareholders and creditors to reduce the cost of the loan and improving the borrower's operating and market performance.

First, I examine whether institutional investors use dual-holding and their subsequent information advantage to trade in the firm's equity and extract rent from other "less-informed" shareholders. If dual-holders are using the material non-public information to make informed trades in the firm's equity, then their trades should generate abnormal profits. I use 13f filings to calculate the change in a dual-holder's equity positions between the loan start date and the

\footnotetext{
${ }^{3}$ Based on conversations with several professionals in the syndicated loans industry, banking institutions are almost always responsible for monitoring of syndicated loans, even in loans with institutional investor participation.
} 
borrower's next quarterly earnings announcement date (event period). I select this time period because during this time dual-holders have access to firm-specific information that other shareholders do not. If a dual-holder's trades reflect the information that is already impounded in the stock price, then on average the dual-holder's trading profitability should be zero. In contrast, I find that dual-holders achieve risk-adjusted abnormal returns of over 6\% (annualized) in their equity investment in firms they have a dual position in during the event period. In comparison, the abnormal return on a buy-and-hold strategy in these firms' shares during the same time period is not statistically different from zero. Consequently, I infer that dual-holders' abnormal profits are a direct result of their informed trades in the firms' equity. My results provide empirical support for dual-holders trading on material non-public information obtained from participation in syndicated-loans, and thus extracting rent from other less-informed shareholders.

Next, I examine whether dual-holders help mitigate the conflict of interest between a firm's shareholders and creditors. Shareholders and creditors often have conflicting objectives due to differences in their payoff structures (Jensen and Meckling 1976). Shareholders' influence can cause a firm's management to engage in activities such as asset substitution and myopic investments. Creditors in turn attempt to mitigate the risk-shifting behavior of shareholders by demanding higher interest rates and imposing more strict covenants on the borrower. Dualholding potentially mitigates the agency-conflict between shareholders and creditors that is exacerbated by the low FRQ of the firm because dual-holders are in essence hedged against the potential wealth transfer from creditors to shareholders. As a result, loans with dual-holders should have more favorable terms for the borrower, namely a lower cost and fewer covenants. Furthermore, if dual-holders mitigate agency conflicts between shareholders and creditors, then shareholders' risk-shifting behavior should decrease, thus improving the borrower's investment 
efficiency, and operating and market performance (see McNichols and Stubben 2008; Parrino and Weisbach 1999; Nini, Smith, and Sufi 2009). I find that in contrast with dual-holders' incentive-alignment, after controlling for the effect of a borrower's FRQ, dual-holding does not lower the cost of the loan. Furthermore, loans of borrowers with dual-holder participation have more covenants. In addition, I find that a firm's operating and market performance do not improve in the year following the dual-holder participation. Taken together, my empirical results do not support the explanation that institutional investors resort to dual-holding in order to align the incentives of shareholders and creditors in firms with low FRQ.

This paper contributes to the literature in several ways. First, while studies such as Bharath, Sunder, and Sunder (2008) recognize the effect of a firm's FRQ on a borrowers' choice of private versus public debt, there are no studies that explicitly examine whether low FRQ of a borrower increases the probability of institutional equity-holders' participation in the firm's syndicated loans. This is the first paper to show that institutional equity investors actively attempt to reduce their information asymmetry and gain access to better information by simultaneously participating in syndicated loans of firms that have low FRQ. Second, previous studies that propose dual-holders take advantage of their unique position in the firm (e.g., Lim 2011; Lim, Minton, and Weisbach 2014) focus on dual-holders extracting rent from the borrower. By identifying dual-holding as a source of investors' private information, I am able to provide evidence that dual-holders extract rent from other less-informed shareholders. Finally, prior studies on dual-holders ignore the effect of FRQ on the cost of a loan, even though Bharath, Sunder, and Sunder (2008) show that borrowers with low FRQ have higher-cost loans. I show that once the FRQ of a borrower is controlled for, dual-holder participation does not affect the cost of the loan. 
My article also complements other studies that examine information leakage from syndicated-loan participants to equity markets in the following ways. First, Bushman, Smith, and Wittenberg-Moerman (2010) provide evidence of information leakage from the syndicated-loan market to the equity market. However, the authors do not identify the channel of private information dissemination to equity-market participants. I directly identify one such channel as dual-holders of debt and equity. Second, Ivashina and Sun (2011) use instances of loan renegotiation to highlight the importance of taking into account the heterogeneity of institutional investors' incentives for participating in syndicated loans, and that not all participants trade on private information. Results reported in this paper complement their study by showing that one class of syndicated-loan participants, namely dual-holders in the firm's syndicated loan and equity, use the private information gained through the syndicated loan to generate abnormal returns.

\section{Hypotheses Development}

\subsection{Financial Reporting Quality and Dual-Holding}

A firm's information risk measures the likelihood that firm-specific information used by market participants to calculate the firm's value is of poor quality. Prior theoretical research has suggested that a firm's information risk is a non-diversifiable risk factor (e.g., Easley and O'Hara 2004); A firm's financial reporting quality is a significant determinant of the firm's information risk (e.g., Ecker et al. 2006; Rajgopal and Venkatachalam 2011). Low FRQ can increase equity investors' cost of collecting and processing firm-specific information (Verrecchia 1980), lead to sub-optimal asset allocation in the less-informed investor's portfolio (Easley and O'Hara 2004; Armstrong et al. 2011), and increase the firm's cost of capital (Francis, Nanda, and Olsson 2008). Regulators have voiced similar concerns. For example, in his 1998 speech, the SEC 
chairman Arthur Levitt expressed concern over firms' rampant earnings management and stated that when firms fail to provide equity investors with high quality financial reports "...the bond between shareholders and the company is shaken; investors grow anxious; prices fluctuate for no discernible reasons; and the trust that is the bedrock of our capital markets is severely tested."

A firm's public financial reports are the primary sources of information available to its shareholders. However, participants in a syndicated-loan of a firm also have access to the firm's material non-public information. Examples of such information include more frequent and detailed financial information, covenant compliance reports, amendment and waiver requests, and any plans for acquisition or disposition of assets. Low FRQ can further increase the information asymmetry of a firm's equity holders compared to its syndicated-loan participants and exacerbate the conflict of interest between shareholder and creditors (Lambert 2001; Lambert, Leuz, and Verrecchia 2007). One way for equity investors of a firm with low FRQ to overcome their information asymmetry is to become dual-holders in the firm by holding its equity and lending to the firm simultaneously. While institutional investors were mostly equityholders in the past, they have increased their participation in the syndicated loan market from just over 30\% of the total loan amount issued in 1995 to $60 \%$ in 2013 (Figure 1). In particular, on average in $40 \%$ of these loans at least one of the lenders was a dual-holder (Table 1, column 8). I define a dual-holder as an institutional investor that holds a position in the firm's equity as well as at least one of its loan facilities in the same year-quarter as the loan start date. ${ }^{5}$ If an institutional investor's incentive for dual-holding is access to material non-public information,

\footnotetext{
${ }^{4}$ Levitt, A., 1998. "The numbers game," https://www.sec.gov/news/speech/speecharchive/1998/spch220.txt.

${ }^{5}$ The reason for choosing loan start date is that other than the loan start date and instances of loan renegotiations, current participants in a syndicated-loan cannot be identified. Ivashina and Sun (2011) show that 100\% of lead arrangers and $83.3 \%$ of co-arrangers remain with the syndicate by the time of its first amendment, while the ratio drops to only $66 \%$ for general participants.
} 
then I would expect to find that the probability of dual-holding is negatively associated with the firm's financial reporting quality. I state my first hypothesis in alternative form as follows:

H1: The probability of institutional investors' dual-holding in a firm is negatively associated with the firm's financial reporting quality.

The above hypothesis is not tautological. If dual-holding of institutional investors is a natural consequence of their increased participation in the syndicated loan market, or if institutional investors have other incentives such as diversification of their revenue sources, then I should not find any relation between financial reporting quality and the probability of institutional investors' dual-holding. Similarly, if dual-holders are risk-averse lenders and only lend to firms with high FRQ, then I should find a positive relation between FRQ and the likelihood of dual-holding.

\subsection{Investors' Incentives for Dual-Holding}

Dual-holders in a firm are shareholders with access to the firm's material non-public information and can use their position in two ways: (1) to trade on the material non-public information obtained by participating in the syndicated-loan and thus extracting rent from other shareholders, and (2) to align incentives of shareholders and creditors.

\subsubsection{Dual-holders and rent-extraction}

A firm's low FRQ motivates investors to gather more private information in order to make more informed trades. Better-informed investors can generate excess returns at the expense of other shareholders (i.e., extract rent) by trading on their information advantage. In particular, equity investors have more incentives to gain access to material non-public information in firms with low FRQ because returns from trading on private information are higher in opaque firms compared with transparent firms (Maffett 2012). Lenders have access to material non-public 
information that is not available to other investors because loan agreements require a borrower to disclose any material information to its lenders in a timely manner. While Regulation Fair Disclosure (Reg FD) prohibits firms from disclosing material information to only a select group of investors, borrowers are not required to publicly release the information that was disclosed to their lenders because such information is protected by a confidentiality agreement between the borrower and its lenders (Ivashina and Sun 2011). Consequently, in this case borrowers are not subject to SEC's Reg FD.

Securities law in the United States also prohibits trading on material non-public information. ${ }^{6}$ However prior studies provide evidence on the positive relation between large block-holders' trading direction and the firm's future performance (Bushee and Goodman 2007), and unusual trading activity in equity, option, and bond markets prior to the announcement of private-equity buyouts (Acharya and Johnson 2010). ${ }^{7}$ These studies explain that the occurrence of informed trades in spite of regulation is because the only way to prove insider-trading is to gather detailed information on investors' transaction history and provide proof on the informed status of traders. While this information is potentially available to government investigators, they do not have the resources to gather data on all institutional investors and thus rely on more obvious signals such as unusual trading activity or unusual price movements.

\footnotetext{
${ }^{6}$ Illegal insider trading refers generally to buying or selling a security, in breach of a fiduciary duty or other relationship of trust and confidence, while in possession of material, non-public information about the security. Insider trading violations may also include "tipping" such information, securities trading by the person "tipped," and securities trading by those who misappropriate such information. The SEC adopted Rules 10b5-1 and 10b52 to resolve two insider-trading issues where the courts have disagreed. Rule 10b5-1 provides that a person trades on the basis of material nonpublic information if a trader is "aware" of the material nonpublic information when making the purchase or sale. The rule however permits persons to trade in certain specified circumstances where it is clear that the information they are aware of is not a factor in the decision to trade, such as pursuant to a preexisting plan, contract, or instruction that was made in good faith. Rule 10b5-2 clarifies how the misappropriation theory applies to certain non-business relationships. This rule provides that a person receiving confidential information under circumstances specified in the rule would owe a duty of trust or confidence and thus could be liable under the misappropriation theory (source: http://www.sec.gov/answers/insider.htm).

${ }^{7}$ I would like to emphasize that I do not claim that any investor in this study has engaged in prohibited activities or is guilty of insider trading.
} 
If dual-holders use the incremental non-public information in firms with low FRQ to trade in the firm's equity, then their trades should generate abnormal profits. In particular, if dual-holders achieve abnormal returns in their trades in the borrower's equity while other equity holders do not, it follows that dual-holders use material non-public information obtained from the syndicated-loan participation to make superior trading decisions in the borrower's equity, thus extracting rent from other less-informed shareholders. The second hypothesis in alternative form is stated as follows:

H2: Dual-holders achieve abnormal returns on their trades in the borrower's equity following loan origination.

\subsubsection{Dual-holders and incentive alignment between shareholders and creditors}

Shareholders' payoff structure resembles that of a call option on the firm value and consequently shareholders' influence could cause a firm's management to engage in activities such as asset substitution and myopic investments (Jensen and Meckling 1976; Leland 1998). This agency conflict is more severe in firms with lower FRQ because the information is generated by reports made by the agent (i.e., the manager) and thus there may be moral hazard problems on the agent reporting truthfully (Lambert 2001). Creditors in turn attempt to mitigate the risk-shifting behavior of shareholders by (1) using loan covenants that impose restrictions on the borrower's investment and financing policy (e.g., capital expenditure, dividend payout, and purchase and sale of assets), and (2) issuing loans with higher interest rates and shorter loan maturities to borrowers with higher perceived risk (Smith and Warner 1979; Aghion and Bolton 1992). Institutional equity-holders who are also lenders to the firm are in essence hedged against the potential wealth transfer from creditors to shareholders and vice versa. Thus, dual-holders provide a unique opportunity to revisit the classic agency-conflict between shareholders and 
creditors and examine whether dual-holders of debt and equity help align the incentives of shareholders and creditors. In particular, I expect the effect of dual-holders' potential incentivealignment to increase as the firm's FRQ decreases.

An empirical challenge is how to measure the change in the agency-conflict between shareholders and creditors. One measure used in prior studies is the number of covenants. In their theoretical model, Aghion and Bolton (1992) provide two mechanisms for how covenants help mitigate the agency conflict between shareholders and creditors. First, covenants are structured ex-ante in such a way that shareholders and creditors agree on desired actions. Second, if incentives of shareholders and creditors cannot be aligned ex-ante, covenants can be structured to transfer control rights to lenders ex-post. Christensen and Nikolaev (2012) identify covenants that correspond to each mechanism. They show that capital covenants (defined as covenants that rely on balance sheet information) align the incentives of shareholders and creditors ex-ante by limiting the level of debt in the firm's capital structure, whereas performance covenants (defined as covenants that rely on income and cash-flow statements) serve at "trip wires" and limit the agency problem by transferring control rights to lenders when the value of their claim is at risk. Performance covenants are not as effective as capital covenants in reducing the agency conflict between shareholders and creditors because shareholders can still take on risky investments as long as these new investments are sufficiently profitable to satisfy performance constraints (Chava, Wang, and Zou 2015). I predict that if dual-holding alleviates the agency conflict between shareholders and creditors, then loans with dual-holder participation have fewer capital and performance covenants. I also expect the influence of dual-holders to be stronger for capital covenants. 
Other measures of incentive-alignment between shareholders and creditors used in prior studies are the cost of the loan and changes in the borrower's investment and operating and market performance. Jiang, Li, and Shao (2010) find that loans with dual-holder participation have lower costs and attribute the lower loan-cost to the incentive-alignment between shareholders and creditors. In addition, the authors argue that dual-holders improve the firm's operating and market performance due to the lower cost of capital and greater incentive of dualholders to increase the equity value of the firm compared to other creditors. ${ }^{8}$ Using a different research methodology, Lim, Minton, and Weisbach (2014) show that dual-holders do not change the cost of the loan unless the dual-holder is a hedge fund or private equity fund, in which case the dual-holder increases the cost of the loan. The authors conclude that such dual-holders are lenders of last resort and thus charge a premium to lend. Nini, Smith, and Sufi (2012) use a sample of borrowers with covenant violations that are far from bankruptcy to show that when both creditors and shareholders play an active role in firms' corporate governance, firms follow more conservative financial and investment policies and experience improved operating performance and valuation.

Given the above discussion, in this study I use the number of loan covenants (e.g., Dichev and Skinner 2002; Chava, Wang, and Zou 2015), loan cost and maturity (e.g., Jiang, Li, and Shao 2010; Lim, Minton, and Weisbach 2014), and changes in a borrower's investment, and operating and market performance (e.g., Nini, Smith, and Sufi 2009; Nini, Smith, and Sufi 2012) as proxies for incentive-alignment between shareholders and creditors in a firm with low FRQ. The third hypothesis is stated in alternative form as follows:

\footnotetext{
${ }^{8}$ However, the authors do not find any improvement in a firm's operating and market performance following the dual-holder's participation.
} 
H3: Dual-holders' impact on reducing the number of covenants and the cost of the loan, and improving the borrower's investment policy, and operating and market performance increases as FRQ of the borrower decreases.

\section{Research Design}

In order to test the effect of borrower's FRQ on dual-holding, I estimate the following probit model at the loan-facility level:

$$
\begin{aligned}
\operatorname{Pr}_{\left(\text {dualholder }_{i j k}=1\right)} & \\
& =f\left(\alpha_{0}+\alpha_{1} F R Q_{i}+\sum_{n} \alpha_{n} X_{i}+\sum_{m} \delta_{m} Y_{k}+\text { year } F E\right. \\
& + \text { Industry } F E)
\end{aligned}
$$

where dualholder ${ }_{i j k}$ is an indicator variable that is equal to 1 if the lender $j$ holds equity of the firm $i$ and also participates in loan facility $k$ in the same year-quarter. $F R Q_{i}$ is the lagged FRQ of firm $i$ (borrower in facility $k$ ) in the year prior to the loan start date. $X_{i}$ is a vector of control variables for the borrower and $Y_{k}$ is a vector of control variables for the facility. The main proxy for the FRQ is the firm's accruals quality, discussed in detail in the next section. Borrower-level variables include controls for growth-firms (book-to-market ratio), size of the firm (log of sales), the borrower's financial health (leverage ratio, three-year industry adjusted return, S\&P rated, and Z-score), and liquidity of the borrower's shares (Amihud's illiquidity ratio). Loan-level controls include the number of participants in the loan and indicator variables for loan purpose (M\&A and LBO), loan type (revolver), and whether the loan is secured.

\subsection{Measurement of financial reporting quality}

Following prior literature, I use accruals quality to proxy for a firm's financial reporting quality (e.g., Dechow, Ge, and Schrand 2010; DeFond 2010). Accruals quality informs investors about the mapping of accounting earnings into cash flows. Low accruals quality weakens this mapping and increases the information risk of investors (Francis et al. 2005). Specifically, I use 
the Dechow and Dichev (2002) measure of accruals quality as modified by McNichols (2002). Accruals quality is measured as the extent to which working capital accruals map into past, current, and future operating cash flows. Assuming that cash flow is the value-relevant construct that earnings is intended to measure, the variability in the mapping of accruals into cash flows captures uncertainty about the valuation implications of accounting earnings. I estimate the following equation using OLS for every year and three-digit SIC industry classification code using all firms in CRSP/Compustat from 2000 to 2014:

$$
W C A_{i t}=\beta_{0}+\beta_{1} O C F_{i t-1}+\beta_{2} O C F_{i t}+\beta_{3} O C F_{i t+1}+\beta_{4} \Delta R e v_{i t}+\beta_{5} P P E_{i t}+\varepsilon_{i t},
$$

where:

$W C A_{i t}=$ working capital accruals for firm $i$ in year $t$, computed as net income before extraordinary items, plus depreciation and amortization minus cash flow from operations; $O C F_{i t}=$ cash flow from operations for firm $i$ in year $t$;

$\Delta R e v_{i t}=$ the change in revenues relative to year $t-1$; and $P P E_{i t}=$ gross property, plant, and equipment.

All variables are deflated by lagged total assets. The residual term $\left(\varepsilon_{i t}\right)$ in the above equation reflects the unexpected accruals. I calculate accruals quality as the standard deviation of residuals over the last four years and dispose of any firms with fewer than ten observations.

\subsection{Measurement of Abnormal Returns}

I follow Brown and Warner (1980) and calculate risk-adjusted abnormal returns on the firm's equity from the syndicate origination date to the firm's quarterly earnings announcement date (event period). I select this time-interval as the event period because: (1) I can be certain that the dual-holder is part of the syndicate (syndicate participants can dispose of their position in the secondary loan market), and (2) during this time period, syndicate participants have access to 
the borrower's financial data that are not publicly available. For each firm I estimate the return equation using daily returns from 250 days to 110 days (approximately 4 months) before the syndicate origination date (estimation period). ${ }^{9}$ I use a one-factor model (unadjusted abnormal returns) and the Fama and French (1993) three-factor model (risk-adjusted abnormal returns) to estimate a firm's expected return. A firm's expected return using the one-factor model is calculated as:

$$
r_{i t}=\hat{\alpha}_{0}+\hat{\alpha}_{1} r_{V W, t}+\varepsilon_{i t}
$$

where $r_{V W, t}$ is the CRSP value-weighted market return on day $t$ and $r_{i t}$ is the daily return of firm $i$. Similarly, a firm's expected return using the three-factor model is calculated as follows:

$$
r_{i t}=r_{f}+\hat{\alpha}_{1}\left(r_{m t}-r_{f}\right)+\hat{\alpha}_{2} S M B_{t}+\hat{\alpha}_{3} H M L_{t}+\varepsilon_{i t}
$$

$r_{m t}$ is the market factor return on day $t$, and $r_{i t}$ is defined as before. $S M B_{t}$ and $H M L_{i}$ are the daily factor-mimicking portfolio returns from Ken French's website. ${ }^{10}$ The coefficients for each return equation are estimated using the firm's daily returns in the four months before the loan origination date. Using coefficients obtained from each regression during the estimation period, I calculate the predicted return for each firm on each day during the event period and then calculate the risk-adjusted abnormal (or excess) return as the difference between the actual and predicted return. The cumulated excess return $(C E R)$ is the sum of the abnormal returns during the event period. Since the event period length is different for each facility-firm pair, I use the number of trading days during the event period to annualize the returns.

\footnotetext{
${ }^{9}$ It takes the lead arranger of a loan approximately 2-3 months to form a syndicate. During this time the leadarranger contacts potential lenders and thus prospective lenders could potentially have access to a borrower's material non-public information. Using an estimation period that ends four months prior to the loan start date avoids any interference in the borrower's equity returns from the possible information leakage and subsequent trading by potential syndicate participants.

${ }^{10} \mathrm{http} / / / \mathrm{mba}$.tuck.dartmouth.edu/pages/faculty/ken.french/Data_Library/f-f_factors.html
} 


\subsection{Dual-Holders' Influence on Loan Characteristics}

I use the following regression to test the effect of dual-holding on the loan characteristics:

$$
\begin{aligned}
\text { Loan_Char }_{i k} & =\alpha_{0}+\alpha_{1} \text { Dualholder }_{i j k}+\alpha_{2} F R Q_{i}+\alpha_{3} F R Q_{i} \times \text { Dualholder }_{i j k} \\
& +\alpha_{4} \text { Lead }_{\text {Lender reputation }}+\alpha_{5} \text { Lead }- \text { lender relation }_{i k} \\
& +\sum_{n} \alpha_{n} X_{i}+\sum_{m} \delta_{m} Y_{k}+\text { year } F E+\text { industry } F E+\varepsilon
\end{aligned}
$$

where Loan_Char ${ }_{i k}$ is the number of a loan's capital or performance covenants, loan amount, loan duration (maturity), or the cost of the loan as measured by the spread over LIBOR. dualholding $_{i j k}$ is an indicator variable that is equal to 1 if lender $j$ holds the equity of firm $i$ and also participates in loan facility $k$ of the firm in the same year-quarter. $F R Q_{i}$ is the lagged financial reporting quality of firm $i$ in the year prior to the facility start date. $X_{i}$ is a vector of control variables for the borrower, namely size (log sales), and risk (S\&P rated firm). ${ }^{11} Y_{k}$ is a vector of control variables for the loan facility.

I include FRQ and its interaction with the dual-holding indicator variable while testing the influence of dual-holders on loan characteristics because prior studies have documented that a firm's financial reporting quality affects characteristics of its debt. For example, Bharath, Sunder, and Sunder (2008) show that firms with low FRQ prefer private debt versus public debt because private lenders have superior information processing abilities and reduce the adverse selection costs to the borrower. Importantly, the authors also demonstrate that low FRQ results in stricter loan terms such as higher interest rate and shorter maturity. Similarly, WittenbergMoerman (2009) examines the effect of information asymmetry between the lenders and borrower and shows that higher information asymmetry between the syndicate participants and

\footnotetext{
${ }^{11}$ All inferences remain unchanged when all controls in equation (1) are also included.
} 
the borrowing firm increases the cost of the loan. Thus, the results of examining the effect of dual-holding on loan characteristics are not reliable unless the effect of FRQ is controlled for.

Following Christensen and Nikolaev (2012) capital covenants are defined as covenants on a firm's (1) quick ratio, (2) current ratio, (3) debt-to-equity ratio, (4) loan-to-value ratio, (5) debt to tangible net-worth ratio, (6) leverage ratio, (7) senior leverage ratio, (8) net-worth, and (9) tangible net-worth. Performance covenants are defined as covenants on a firm's (1) cash interest-coverage ratio, (2) debt-service coverage ratio, (3) level of EBITDA, (4) fixed-charge coverage ratio, (5) interest coverage ratio, (6) debt to EBITDA ratio, and (7) senior debt to EBITDA ratio. Capital covenants ratio (performance covenant ratio) is defined as the number of capital (performance) covenants divided by the total number of covenants. I separate the two sets of covenants instead of using the total number of covenants because each set has a different purpose (e.g., ex-ante incentive alignment of capital covenants versus ex-post contingent control transfer of performance covenants). Using the total number of covenants ignores differences in characteristics of these covenants. Because of the upward trend in the use of capital covenants after the financial crisis of 2006-2007, I also control for year and industry fixed-effects in all regressions.

I also include variables for prior lending relationships between the lead-arranger and the borrower, as well as the lead-arranger's reputation because the lead-arranger's characteristics also influence the loan's features. Dual-holders are exposed to both debt and equity of a firm and thus it is possible that they only select loans that they perceive to have lower risks. Consequently, dual-holders might be more willing to lend at better terms to a borrower if the lead-arranger is highly reputable or has had prior lending relationships with the borrower because in such instances the lead-arranger is perceived to be more informed (Sufi 2007). 
Lead-lender relation $i k$ is an indicator variable that equals 1 if the lead-arranger of facility $k$ was also the lead-arranger in another loan to borrower $i$ within the past five years. Lead lender reputation $_{k}$ is an indicator variable that equals 1 if the ratio of the dollar amount of loans issued by the lead-arranger in year $t-1$ scaled by total dollar amount of loans issued by all lenders in year $t-1$ is greater than $5 \%$.

\subsection{Dual-Holders' Influence on the Firm's Operating and Market Performance}

I examine the influences of dual-holders on the borrower's investment and operating efficiency using the following OLS model at the facility level:

$$
\begin{aligned}
& \Delta \text { Firm__har }_{i k, t+1} \\
& \quad=\alpha_{0}+\alpha_{1} \text { Dualholder }_{i j k}+\alpha_{2} F R Q_{i, t-1}+\alpha_{3} F R Q_{i, t-1} \\
& \quad \times \text { Dualholder }_{i j k}+\sum_{n} \alpha_{n} X_{i t}+\text { year } F E+\text { industry } F E+\varepsilon,
\end{aligned}
$$

where $\Delta$ Firm_Char ${ }_{i k, t+1}$ is the change in one of the six borrower's characteristics in three categories (Nini, Smith, and Sufi 2012): (1) changes in the borrower's investments (total assets, plant, property, and equipment, and capital expenditure), (2) changes in the borrower's financial health (total debt, total cash, and shareholder payout), and (3) changes in the borrower's operating performance (operating cash flow, sales, and SG\&A). dualholder ${ }_{i j k}$ is an indicator variable that is equal to 1 if lender $j$ holds the equity of firm $i$ and also participates in loan facility $k$ of the firm in the same year-quarter. $F R Q_{i}$ is the lagged financial reporting quality of firm $i$ in the year prior to the facility start date.

I include controls for the borrower's financial health because when a borrower is in financial distress its lenders increase their monitoring and have more control over the firm's operations compared to its shareholders. The control variables I use are ones that are most often used in financial covenants, namely operating cash flow to assets, leverage, interest expense to assets, net worth to assets, and current ratio. I further include book to market ratio to control for 
growth versus value firms. $X_{i t}$ is the vector of control variables for the borrower as described before.

\section{Data and summary statistics}

The primary data sources for equity holdings and syndicated-loan participation of investors are Thomson Reuters Institutional Ownership database and Loan Pricing Corporation (LPC) DealScan, respectively. I use a more recent sample compared to prior studies. I obtain firms' financial information from COMPUSTAT, and quarterly institutional ownership data from January 2002 to June 2014 from $13 \mathrm{f}$ filings in the Thomson Reuters database. ${ }^{12}$ Syndicatespecific information is from DealScan database from January 2007 to June 2014 and consists of 98,842 facilities from 32,762 borrowing firms. I remove observations that are missing the following information: borrower name, facility start date, facility amount, or loan maturity. I restrict the data to U.S. borrowers and limit the observations to facilities where the cost of the loan is not missing and LIBOR is the base rate. Following prior literature, I also exclude bankers' acceptance, bridge loans, standby letters of credit, performance standby letters of credit, multi-option facilities, and loans that are categorized as "other" or "undisclosed." This screening process results in 29,436 facilities, associated with 19,510 loans made to 10,560 borrowing firms.

I divide lenders into bank and non-bank institutional investors. Lenders that are banking institutions are identified as follows. First, a lender is classified as a commercial bank if its primary four-digit SIC Code in DealScan (6011-6082, 6712, or 6719) or its Thomson Financial institution type code (type code $=1$ ) indicates that it is a commercial bank. Second, a lender is a

\footnotetext{
${ }^{12}$ A $13 \mathrm{f}$ form must be filed within 45 days after the end of March, June, September, and December by all institutional managers who exercise investment discretion over $\$ 100$ million or more in total securities. The $13 \mathrm{f}$ lists the securities, the number of shares owned, and the market value of each investment. Managers are permitted to exclude from their filing any holdings that are fewer than 10,000 shares and $\$ 200,000$ aggregate fair market value.
} 
commercial bank if the institution has major commercial banking operations (i.e., it accepts deposits). Third, the lender's type in DealScan is "U.S. Bank," ends in "Bank," or is “Thrift/S\&L." Non-commercial banking institutions are divided into seven categories using their type in DealScan as well as Bloomberg and SIC classification: investment bank (SIC code 6211), insurance company (SIC code 6311-6361, 6399, or 6411) finance company, mutual fund, hedge or vulture fund, pension fund, and other. The detailed sample selection procedure is shown in Panel A of Table 2.

A major challenge in constructing the sample is that there is no matching table between the fund names listed in $13 \mathrm{f}$ filings in the Thomson Reuters database and lender names in DealScan. Furthermore, the name of the fund listed in its $13 \mathrm{f}$ filing is usually different from the name of the lender used in the DealScan database. The fund and/or the lender could also belong to a subsidiary or parent of a firm. Thus in order to match each fund in the $13 \mathrm{f}$ database to a lender in DealScan, I manually match each fund in the $13 \mathrm{f}$ database to a lender in DealScan. To identify the fund(s) that correspond to each lender, I search Bloomberg and BusinessWeek online resources, as well as firms' SEC filings. Next, I check each firm, as well as its parent(s) and all direct subsidiaries to see if it also exists as a lender in the DealScan database. Panel B of Table 2 shows the results of this manual matching procedure.

Overall, there are 201 non-bank lenders and 245 bank lenders that are matched from the 13f database to the DealScan database during the sample period. Non-bank lenders exist in 2,281 facilities, while bank lenders exist in 6,537 facilities. Furthermore, in $78 \%$ of facilities, major participants in the facility also held a significant equity position (defined as either a total equity ownership greater than $\$ 2 \mathrm{M}$ or $2 \%$ of total shares) in the borrower. For a loan to have dual holders, I require at least one of the lenders (or one of their subsidiaries) in the facility to have an 
equity holding in the borrowing firm or in the borrower's parent firm in the same year-quarter in which the loan is originated. I match the borrower to CRSP/COMPUSTAT following Chava and Roberts (2008) and obtain the GVKEY for each borrower. Using this GVKEY, I construct borrower level control variables from IBES, CRSP/COMPUSTAT, and the Thomson Reuters databases. I retrieve managers' forecast data from Thomson Reuters First Call database from 2000 to 2011, when the database was discontinued. Institutional investor classification data is downloaded from Brian Bushee's website for 2000 to 2013. Panel C of Table 2 shows the number of unique facilities for each type of institutional investor. Most non-bank dual-holders are finance companies, followed by investment banks. Panel D shows the distribution of the dual-holders by their investment horizon. $27 \%$ of non-bank dual-holders versus $23 \%$ of banking dual-holders are categorized as transient investors who are more inclined to trade on private information and follow short-term trading strategies.

Table 3 displays the summary statistics of variables. Similar to Lim, Minton, and Weisbach (2014), I find that non-bank dual-holding facilities are larger than bank dual-holding facilities. Non-bank dual-holding facilities have more lenders per facility and their facilities have longer maturities. Borrowers with bank dual-holding facilities are larger as measured by their asset size, and have slightly lower Altman's Z-score, higher leverage, higher sales growth, and higher liquidity. Furthermore, borrowing firms with non-bank dual-holders have a higher number of analysts and lower analyst disagreement. The statistics in this table are not consistent with Lim, Minton, and Weisbach (2014) that borrowers with non-bank dual-holders are firms with higher risk. The differences between facilities (and borrowers) with non-bank dual-holder participation versus non-bank non-dual-holder participation are similar to the differences between non-bank and bank dual-holding facilities (and borrowers). 


\section{Empirical Analyses}

\subsection{Financial Reporting Quality and Dual-Holding}

In this section, I explore whether FRQ is associated with the probability of dual-holding. In particular, I examine whether a firm's FRQ is negatively associated with the likelihood of investors' dual-holding in the firm. As a robustness test, I also examine whether a firm's FRQ is negatively associated with the likelihood of banking institutions' (i.e., commercial bank) dualholding. Banking institutions are different from other institutional investors in that they have a lower incentive to gain access to better information through dual-holding due to their different business model. Banking institutions are mainly interested in generating fees from cross-selling activities such as monitoring of the loan. Consequently, the low FRQ of a borrower is less likely to increase the probability of banking institutions' dual-holding in that firm.

In Table 4 I examine the relationship between FRQ and investors' participation in the loan. Because accruals quality of a firm is highly correlated with its size, I first sort firms into size deciles (using a firm's market value) and then into accruals-quality terciles within each size decile (dependent sort). I control for the firm-size in the univariate analysis using this dependent sort methodology so that firms in the low (high) FRQ tercile do not necessary belong to smaller (larger) firms. The accruals quality measure is multiplied by -1 so that a lower (more negative) value represents a lower financial reporting quality. Panel A displays results for loans with nonbank and bank-only participants, and Panel B repeats the analyses for loans with dual-holders. Panel A shows that institutional investors' participation is higher in loans of firms with lower accruals quality, while banking institutions are more likely to lend to firms with higher FRQ. Similarly, Table 4 Panel B shows that more non-bank investors are dual-holders in firms with 
low accruals quality, while banks actually display a reverse pattern. The inferences also hold using different measures of accruals quality.

Next, I examine the relationship between FRQ and institutional investors' participation in the syndicated loan using the probit model in equation (1). Panel A of Table 5 presents the results. The dependent variable is institutional investor participation in column (1) and bank participation in column (2). Both regressions are estimated at the loan-facility level with industry and year fixed effects controlled for. The independent variable of interest is FRQ, which is the accruals quality of the borrower lagged by one year to avoid look-ahead bias. In column (1), the coefficient of FRQ is negative and significant for institutional-investor participation, indicating that as the accruals quality of the firm decreases, the probability of investor participation in the syndicated loan increases. Using marginal probabilities, a one-percentage point improvement in a borrower's accruals quality reduces the likelihood of institutional-investors' participation in the firm's syndicated-loan by 81 basis points (significant at $1 \%$ level), keeping all other variables at their mean. Thus there is an almost one-to-one relationship between the decrease in accruals quality and the increase in the marginal probability of non-bank investors' participation in the syndicated-loan. In contrast, the coefficient of FRQ is not statistically different from zero for banking-institutions' participation (column 2), which is consistent with such investors having different incentives for participating in the syndicate loan of a firm, such as cross-selling fees from non-credit venues (e.g., cash and fund management, and M\&A advisory of the borrower).

Panel B of Table 5 displays the results of the probit model in equation (1) to determine the likelihood of institutional-investor dual-holding (columns 1 and 3) and bank dual-holding (columns 2 and 4) given a borrowers' FRQ. In columns (1) and (2) I use the entire sample, while in columns (3) and (4) I restrict the sample to loans with institutional investor participation. The 
coefficient FRQ is negative and statistically significant in columns (1) and (3), meaning that as the FRQ of a borrower decreases, the probability of non-bank dual-holding in the firm increases. I also examine the marginal probability of FRQ in column (1) and find that a one-percentage point increase in the firm's FRQ decreases the probability of dual-holder participation in the firm's syndicated loan by 83 basis points (significant at $1 \%$ level), keeping all other variables at their mean. Put in other terms, moving from the first (worst) to the last (best) FRQ decile decreases the likelihood of non-bank dual-holder participation in the firm from $28 \%$ to $19 \%$, a $47 \%$ decrease in the probability of dual-holding. More importantly, and consistent with banks having different incentives for lending to a firm, in columns (2) and (4) the FRQ of the borrower is not a significant determinant of bank dual-holding. In summary, the results presented in this section confirm H1, and that the probability of institutional investors' dual-holding in a firm is negatively associated with the firm's FRQ.

As a robustness check, I also use two alternative measures of FRQ: analyst disagreement and instances of managers earnings forecast. Analyst disagreement is measured using the standard deviation of analysts' one-year EPS forecast of the firm divided by the average forecasted EPS. ${ }^{13}$ Instance of managers' forecast is defined as an indicator variable that equals 1 if the manager provides earnings forecast from the FirstCall database and 0 otherwise. If the firm's management has never provided an earnings forecast, the variable is set to null. I repeat the analyses using these two alternative measures of FRQ and all inferences remain unchanged.

In the next section I investigate how non-dual-holders influence loan and borrower characteristics following the loan start date.

\footnotetext{
${ }^{13}$ Inferences remain unchanged using the two-year EPS forecast.
} 


\subsection{Investors' Incentives for Dual-Holding}

In the previous section I illustrated that institutional investors are more likely to become dual-holders in firms with low FRQ. In this section I examine how dual-holders benefit from their unique position in the firm by asking (1) do dual-holders use their access to material nonpublic information to make informed trades in the borrower's equity and thus extract rent from less-informed shareholders, or (2) do dual-holders use their unique position to mitigate the conflict of interest between shareholders and creditor?

\subsubsection{Dual-holders and rent-extraction}

If dual-holders use material non-public information obtained through the syndicate to make informed trades in the borrower's equity, I expect these trades to generate abnormal returns. I calculate each fund's abnormal returns using the methodology described in the research design section for the time period from the syndicate origination date to the borrower's next quarterly earnings announcement date. Following Ivashina and Sun (2011) and using the fund's 13f filings, I multiply the abnormal returns by -1 if the dual-holder decreases their position in the borrower. ${ }^{14}$ I treat unchanged positions in two ways: first, as a weight equal to 0 (called "excluding unchanged holding"), and second, as a weight equal to 1 (called "including unchanged holding") since no change in the equity position could also be interpreted as a positive signal. Because the number of days in the event period varies for each facility and firm, I annualize all returns. Expected returns for each firm are calculated using both the market model (Table 6, Panel A) and the Fama-French three-factor model (Table 6, Panel B).

The mean and median returns of non-bank dual-holder's portfolio returns are displayed in columns 1 and 2 of Panels A and B of Table 6. Non-bank dual-holders on average achieve

\footnotetext{
${ }^{14}$ Exact dates of a fund's trades are not available because institutional investors' equity holdings are disclosed through quarterly $13 \mathrm{f}$ filings on a quarterly basis.
} 
abnormal returns in excess of $5 \%$ during the event period using the market model. Using the Fama-French three-factor model (Panel B), abnormal returns of non-bank dual-holders are in excess of $6 \%$ during the event period. As an additional test, I also calculate abnormal returns of bank dual-holders. The cumulative abnormal return of bank dual-holders during the same time interval is displayed in column 2 of Panels A and B. In contrast to non-bank dual-holders, abnormal returns of bank dual-holders are either not statistically different from zero (Panel A) or are much smaller (Panel B). Results in this table suggest that non-bank dual-holders generate excess returns. One explanation is that non-bank dual-holders gain an information advantage over other shareholders by accessing the material non-public information obtained from the syndicate and making more informed trades in the firm's equity. As a robustness check, and to ensure that firms with dual-holders do not simply experience abnormal returns following the syndicate origination, I calculate abnormal returns using a simple buy-and-hold strategy during the same time period, and find that cumulative abnormal returns generated following this strategy are not statistically different from zero. Together, these results highlight the importance of managers' specific trading strategy in generating abnormal returns.

In addition to overall returns, I also divide returns by the direction of the trade (buy and sell) to examine whether fund managers generate abnormal returns by adjusting their positions according to the information received from the borrower (as opposed to always following a buy or sell strategy following the loan start date). Results are displayed in Panel C of Table 6 and show that funds' abnormal returns generated from buy and sell transactions are similar in both number and magnitude. These results suggest that dual-holders are able to generate abnormal returns by strategically increasing or decreasing their position according to the material nonpublic information disclosed by the borrower to its lenders. 
In the previous section I showed that non-bank investors are more likely to become dualholders in firms with low FRQ. An interesting follow-up question is whether a dual-holder's returns vary by the FRQ of the borrower. To answer this question, I divide borrowers into terciles by their FRQ and examine dual-holders' abnormal risk-adjusted returns in the low versus high FRQ group. The results are shown in Table 7, in Panel A with terciles formed on the total accruals, and in Panels $\mathrm{B}$ and $\mathrm{C}$ with terciles formed using the innate and discretionary components of accruals. Panel A shows that there is no significant difference in dual-holders' returns between the low and high FRQ terciles. However, Panels B and C show that dual-holders are able to achieve higher abnormal returns by trading in firms with high innate and low discretionary accruals quality. As Francis et al. (2005) explain, discretionary accruals potentially reflect managers' opportunism. Through dual-holding, institutional investors gain better access to a borrower's management and firm-specific information not available to other shareholders, thus enabling the dual-holder to make more informed trades.

Next, I examine whether the relative value of a dual-holder's equity to loan holdings influences the dual-holder's incentive to extract rent. I divide dual-holding funds into quintiles based on their equity to loan ratio and measure abnormal returns for each quintile. For each fund, the market value of an equity position is calculated by multiplying the number of shares reported by the share price at the end of the quarter. The value of each lender's loan is calculated by multiplying the lender's percentage ownership in the loan by the total dollar value of the loan. Abnormal risk-adjusted returns of dual-holders during the sample period for each quintile of equity-to-loan ownership are reported in Table 8. Panel A reports the results for the overall sample, and Panels B and C further divide the returns into gains and losses. Dual-holders with equity-to-loan ratio in the third (middle) quintile are able to generate the highest abnormal 
returns (and lowest losses). Dual-holders in the bottom quintile with small equity positions compared to their loan holdings are institutions that are interested in generating revenues from lending activities. Another explanation is that fund managers are only required to disclose their long positions and thus it is likely that funds in lower quintiles generate abnormal returns using short positions or financial derivatives. Similarly, funds in higher quintiles have a significant equity position in the lender. As Bushee and Goodman (2007) show, institutions with large equity positions have access to material non-public information and are more likely to execute profitable trades based on these private information on earnings. Consequently, for these investors the abnormal returns are not restricted to the time period between the loan start date and the next earnings announcement date.

Dual-holders' excess returns calculated above using changes in dual-holders' equity holdings in a borrower are achieved in a relatively short time-period. Such investors are not able to engage in repeated short-term trades in the same borrower because such behavior will attract other investors' (and regulators') attention. Consequently, these investors are more likely to be short-term investors and not have a long investment horizon. Bushee and Goodman (2007) show that "growth-style" investors have a strong incentive to gather private information and profit from short-term trades, while "value-style" investors are long-term investors and do not show evidence of informed trading. I divide investors by their investment horizon based on the classifications in Abarbanell, Bushee, and Raedy (2003) and calculate abnormal returns for each group. Consistent with the dual-holder rent-extraction hypothesis, I find that $88 \%$ of dual-holders are "growth-style" investors and generate abnormal returns in excess of $6 \%$ (significant at $1 \%$ level), while "value-style" investors' abnormal return is only $1 \%$ and is not statistically different from zero. 


\subsubsection{Dual-holders and incentive alignment between shareholders and creditors}

Next, I examine the effect of dual-holders on the number of loan covenants. If dualholders align the incentives of shareholders and creditors, then I expect loans with dual-holders to have fewer capital and performance covenants. Furthermore, I expect the relation between dual-holding and the number of covenants to be stronger in borrowers with lower FRQ. I also control for the lead-arranger's reputation (measure of lead-arranger's monitoring effort) and lead-arranger's prior lending relations with the borrower (measure of the information asymmetry between the borrower and the lead-arranger). Panel A of Table 9 shows the results of the model in equation (3) estimated using OLS with the log ratio of capital covenants (columns 1 and 3) and the $\log$ ratio of performance covenants (columns 2 and 4) as the dependent variable of interest. ${ }^{15}$ Columns (1) and (2) show the results using the full sample, and columns (3) and (4) show the results using the sample of loans with non-bank investor participation. Coefficients on dual-holder indicator variable show that dual-holding does not influence a loan's capital covenants (columns 1 and 3), and only weakly affect performance covenants (column 2). In particular, the coefficient on the interaction variable between FRQ and dual-holding is only significant in column (2) and it is negative. Thus, as the FRQ of the borrower decreases, dualholding increase the number of the loan's performance covenants in firms with low FRQ and I do not find any evidence that dual-holding alleviates the agency conflicts between shareholders and creditors.

Next, I examine the influence of dual-holders on loan characteristics, namely the facility amount, loan maturity, and loan cost. First, I replicate the results of Jiang, Li, and Shao (2010) using my sample data (untabulated). Consistent with the authors' results, I find that if FRQ is not

\footnotetext{
${ }^{15}$ Inferences remain unchanged if the number of covenants is used as the dependent variable instead of the covenant ratio.
} 
included in the model, dual-holding results in a reduction in the cost of the loan. Next, I repeat the analyses but control for the borrower's FRQ. The results are shown in Panel B of Table 9 and highlight the importance of controlling for the borrower's FRQ when examining the influence of dual-holding on loan-characteristics. The coefficient on the FRQ is negative in columns (3) and (6). Consistent with findings of Bharath, Sunder, and Sunder (2008), as the FRQ of the borrower decreases the cost of the loan increases. Dual-holding only weakly increases the loan amount and decreases the loan maturity in the full-sample (columns 1 and 2), and does not significantly influence the loan characteristics in the institutional investor sub-sample (columns 3, 4, and 5). Overall, my results do not provide evidence consistent with the incentive-alignment of dualholders.

\subsubsection{Dual-holders and changes in the firm's operating and market performance}

If dual-holders mitigate the conflict of interest between shareholders and creditors, then the borrower's investment and operating and market performance should improve following the dual-holders' participation in the loan. As a final test, I study whether dual-holders aid in the incentive-alignment between shareholders and creditors by examining (1) the change in the borrower's investment (total assets, plant, property, and equipment, and capital expenditure), (2) the change in the borrower's financial health (total debt, total cash, and shareholder payout), and (3) the change in the borrower's operating performance (operating cash flow, sales, and SG\&A) in the year following the syndicated loan origination (see Nini, Smith, and Sufi 2012). I estimate the model specified in equation (4) using OLS at the borrower level. ${ }^{16}$ The results are shown in Table 10. Panel A shows the results for the full sample and Panel B shows the results for the sample restricted to loans with institutional investor participation. In Panel A, coefficients on indicator variable for dual-holding suggest that firms with dual-holders improve their financial

\footnotetext{
${ }^{16} \mathrm{I}$ also repeat the test using panel data at firm level. All inferences remain unchanged.
} 
and operating performance by reducing shareholder payout and SG\&A (columns 6 and 9). However, these borrowers also have decreased sales and investments in PPE (columns 8 and 2). Importantly, coefficients on the interaction variable in columns (6) and (9) suggest that as the FRQ of borrowers with dual-holder participation decreases, shareholder payout and SG\&A increase in the year following loan origination, thus conflicting with the incentive-alignment effect of dual-holders. The coefficient on the interaction variable in column (2) is however consistent with the incentive-alignment hypothesis and shows that firms with low FRQ have higher investment in PPE following dual-holder participation. Overall, the results in this table confirm that the evidence on dual-holders' incentive-alignment is mixed at best. Inferences from Panel B (using a sample restricted to loans with institutional-investor participation) are similar to those from Panel A.

Finally, I explore whether dual-holders align the incentives between the borrower and lenders by examining the change in firm's book-to-market, return on assets (ROA), operating margin (EBITDA/Sales), and return on equity following the loan origination. I estimate the model using OLS with changes of the above variables as dependent variables. The results (untabulated) indicate no statistically significant improvement in the firm's market performance or operating efficiency following dual-holder participation in a loan. As a second measure, I also examine whether R\&D and advertising expenses of the borrower change following dual-holder participation in the loan and find similar results. In summary, results of tests in this section provide mixed empirical evidence consistent with the incentive-alignment between shareholders and creditors following a dual-holder's participation in a firm's loan. 


\section{Additional analyses}

\subsection{Controls for the Potential Endogeneity of Financial Reporting Quality}

Similar to most studies on financial reporting quality, one important challenge in this paper is the potential endogeneity due to omitted correlated variables or reverse causality. I have implemented several research-design features to mitigate these concerns. First, I include multiple factors that are identified by prior literature to influence dual-holding as control variables. Second, to reduce the possibility of reverse causality, I use the lagged value of FRQ to predict the probability of dual-holding in the next period. Third, my main test-results are robust to using alternative discretionary accruals models, as well as other proxies for firms' information quality such as analyst disagreement.

As an additional control for the potential endogeneity of FRQ, I consider a two-stage least-squares probit model using the instrumental variable approach. I choose the natural log of a firm's non-audit fees as the instrument because prior studies such as Srinidhi and Gul (2007) and Frankel, Johnson, and Nelson (2002) document that non-audit fees are associated with increased earnings management and lower accruals quality. I confirm the validity of using the log nonaudit-fee as an instrument for FRQ by confirming that as predicted, it has a significant negative correlation with the accruals quality of the firm. Furthermore, I am not aware of any economic or empirical model that predicts non-audit fees significantly influence the likelihood of dualholding in the firm, except through financial reporting quality of the firm. The results are displayed in Table 11 and show that inferences are not affected after controlling for the potential endogeneity of the FRQ of the firm using the two-stage estimation method. 


\subsection{Controls for the Potential Endogeneity of Dual-Holding}

In testing the influence of dual-holders on the loan and firm characteristics, it is possible that the investors' dual-holding is endogenous due to dual-holders' possible selection effect. I address this concern in several ways. First, to control for the possibility of dual-holder participation in loans of firms in industries with higher risk, in all specifications I include industry fixed-effects along with year fixed-effects. Second, I include both firm-level and loanlevel variables that could influence future firm performance and loan characteristics as control variables. Finally, I use a two-stage least-squares model to account for the possible endogeneity of dual-holding in testing the dual-holders' influence on the cost of the loan. Following Jiang, Li, and Shao (2010), I use the liquidity of a firm's equity as the instrument for the investor's dualholding. Institutional investors (and thus dual-holders) are more likely to invest in firms with more liquid shares. Any influence of the liquidity of the firm's shares on the cost of the firm's loans is likely to be the result of increased participation of institutional investors in the firm's equity, and thus does not directly affect the loan-cost. The results are displayed in Table 12 and show that the inferences remain unchanged after controlling for the potential endogeneity of dual-holding using the two-stage estimation method.

\subsection{Controls for the Size of Dual-Holders' Equity and Loan Holding}

I next examine whether dual-holders' incentives differ depending on the size of their debt and equity holdings. For example, would a dual-holder with a larger share of the firm's loan or equity be less inclined to extract rent from the firm? On average, institutional dual-holders own $12 \%$ of the loan and $1 \%$ of the firm's equity. ${ }^{17}$ Using the average facility and equity value of firms in the sample, these percentages correspond to approximately $\$ 60$ million in each of syndicated-loan and equity of the firm. In comparison, bank dual-holders on average hold $33 \%$

\footnotetext{
${ }^{17}$ Institutional investors that are not dual-holders on average hold $11.9 \%$ of the syndicated loan.
} 
of the loan and $0.4 \%$ of the equity of a firm. ${ }^{18}$ Bushee and Goodman (2007) examine instances of institutional investors' trades on private information and find that institutions with large equity positions are more likely to execute profitable trades based on private information on earnings. This result is intuitive since large shareholders are more likely to have access to the firm's material non-public information. Results of tests for $\mathrm{H} 2$ suggest that dual-holders potentially trade on the firm's material non-public information. If dual-holding and large equity ownership are two alternative channels for an institutional investor to gain access to a firm's material nonpublic information, then a large shareholder is less likely to be a dual-holder and vice versa. Accordingly, I expect the rent-extraction of dual-holders (as measured by their abnormal profits generated during the event period) to be larger for dual-holders with smaller percentage of shares in the firm. I calculate each lender's equity-holding in the borrower as the percentage of the total shares outstanding in the year-quarter of the facility origination. I divide the funds into low (below-median) and high (above-median) equity-holding and calculate the abnormal return for each group. For low equity-holding funds, the accumulated abnormal return is $9 \%$ (on an annual basis) and is statistically significant at $5 \%$. In contrast, the accumulated abnormal return for the high equity holding group is not statistically different from 0 . These results further confirm that dual-holding acts as a substitute for large equity ownership for institutional investors to gain access to a firm's material non-public information.

I also examine whether dual-holders behave differently depending on their share of the loan. If dual-holders' main objective for participating in a loan is to gain access to the borrower's material non-public information, then I would expect dual-holders to take on smaller shares of

\footnotetext{
${ }^{18}$ Banking institutions are expected to hold a larger share of the loan because (1) as lead arrangers and monitors of the loan they are required to hold a larger share of the loan and increase their "skin in the game" to alleviate the moral hazard problem between the lead arranger and other syndicate members, and (2) lending activities are a major source of a bank's revenues.
} 
the syndicated loan to minimize transaction costs. I divide dual-holders into two groups: high (above median) and low (below median) ownership of syndicated-loan allocation. I calculate the abnormal return of each group during the event period. The abnormal return for dual-holders with lower syndicate allocation is $12 \%$ (annualized) and significant at $1 \%$ level. In contrast, the abnormal return for the high loan-allocation group is not statistically different from zero. Results of these tests based on dual-holders debt and equity ownership confirm the dual-holder rentextraction hypothesis and cast doubt on the incentive-alignment effect of dual-holders suggested by prior literature.

\subsection{Institutional Lenders with Prior Equity Positions}

Ex-ante it is not clear whether a dual-holder with an equity position prior to participating in the syndicated loan of a firm and a dual-holder with an equity position initiated in the same quarter as the loan origination have similar incentives. It is possible that dual-holders with prior equity holding in the firm have incentives other than access to better information, or already have access to a firm's material non-public information using their equity position. I examine whether the relation between FRQ and dual-holding weakens for dual-holders with a prior equity position in the firm by re-defining dual-holders as institutional investors with an equity position one quarter prior to participating in the syndicated loan. I repeat the tests for all three hypotheses using this new sample. 1,388 facilities have lenders with prior equity ownership in the borrower

(compared to 1,375 facilities that have lenders with simultaneous equity ownership). All inferences remain unchanged and the results are similar in magnitude and statistical significance to ones reported using the original sample of dual-holders. 


\subsection{Institutional Lenders with Equity Positions in the Next Quarter}

An additional possible scenario is when a lender participates in the equity of the borrower after the loan start date. If the reason for institutional investors' dual-holding is access to better information and extracting rent from other less-informed shareholders, then the accounting quality of the borrower should have a lower impact on the likelihood of a lender's equity-holding after the loan start date. I repeat the tests of $\mathrm{H} 1$ using this new definition of dual-holding. 1,352 of 6,821 facilities have lenders that consequently hold the equity of the borrower in the next quarter. The results are tabulated in Table 13. As expected, the relation between FRQ and dualholding is weaker in this scenario compared to the original definition of dual-holders: moving from the first (worst) to the last (best) FRQ decile decreases the likelihood of non-bank dualholder participation in the firm from $16 \%$ to $12 \%$ (compared to $28 \%$ and $16 \%$ in the original analyses). Importantly however, lenders are still more likely to hold equity of borrowers with lower FRQ, consistent with the increased opportunity for rent extraction in such firms.

\section{Conclusion}

I investigate the effect of the quality of a firm's publicly available financial information on the incentive of institutional investors to simultaneously participate in the firm's equity and syndicated loans. I demonstrate that institutional investors are more likely to become dualholders in firms with low FRQ. I also explore how dual-holders use their unique access to a borrower's material non-public information. Using the change in the equity position of dualholders from their $13 f$ filings, I show that dual-holders achieve an abnormal return of over $6 \%$ (on annualized basis) by trading in the borrower's equity from the syndicate origination date to firm's next quarterly report announcement date. I also examine whether dual-holding mitigates the conflict of interest between shareholders and creditors because dual-holders are in essence 
hedged against any wealth-transfer from one stakeholder group to the other. I show that dualholders' participation in the syndicated loan of a firm does not result in more favorable loanterms once the financial reporting quality of the borrower is controlled for. I further examine changes in the borrower's investments, financial health, and operating and market performance in the year following the syndicated loan origination and find that the firm's financial and operating performance do not improve. Thus, the results do not provide adequate empirical support for dual-holders' incentive-alignment hypothesis. The results in this study lend empirical support to the argument that dual-holders extract rent from other less-informed shareholders by using the material non-public information gained through syndicate participation to make more informed trading decisions in the borrower's equity. 


\section{Chapter 2: Consequences of Trading on Private Information: Evidence from Dual-Holders}

\section{Introduction}

Traditionally, syndicated loan participation was limited to banking institutions. However with the increase in the number and size of non-bank institutional investors in recent years, many syndicates now have a mix of banking and non-banking institutions as participants. An interesting consequence of non-banking institutions participation in syndicated loans is that in some cases the institutional investors who lend to the firm are simultaneously holding the firm's equity (dual-holders from hereon). One important distinction between regular shareholders and dual-holders is the firm specific information that is available to dual-holders. Participants in a syndicated loan have access to additional information that is presented more frequently (normally on a monthly basis), while the shareholders' main source of firm-specific information is the firm's quarterly reports disclosed publicly. Consequently, dual-holders can use their access to material non-public information to make more informed trades in the borrower's equity and generate excess returns (Peyravan 2016).

Dual-holders are considered informed investors because they have access to additional and more frequent firm-specific information compared to other shareholders. Prior theoretical literature examining the influence of informed traders on a firm's overall information environment has reached conflicting conclusion. On one hand, the informed investors' participation in the market increases the firm's level of information asymmetry perceived by uninformed investors, causing them to demand additional compensation to trade with the informed investors (e.g., Kyle 1985, Glosten and Milgrom 1985). On the other hand, as informed investors take advantage of their additional information by trading in the firm's equity, the firm's equity price will adjust to firm-specific information faster, consequently improving the firm's 
information environment (e.g., Holden and Subrahmanyam 1992). Importantly however, prior literature has not considered how informed investors influence the firm's disclosure policies. In this empirical study, I use hand-collected data on lenders that simultaneously hold equityposition in the borrower (i.e., dual-holders) to examine how informed investors influence the firm's information environment. I find that dual-holders decrease the firm's information uncertainty by increasing the price informativeness of the borrower's equity. I also investigate whether dual-holders reduce the information asymmetry between the informed and uninformed investors in the firm by causing equity prices to reflect firm-specific information more quickly. Using changes in the bid-ask spread and liquidity during the earnings announcement period, I find that firms with dual-holders experience a lower bid-ask spread and higher liquidity compared to firms without dual-holders. Additionally, firms with dual-holders also have lower analyst forecast dispersion and smaller abnormal returns during the earnings announcement period, further signifying the influence of dual-holders on decreasing the firm's information uncertainty.

Importantly, I study the effect of dual-holders on a firm's voluntary disclosure. Monitoring of a firm's management is costly to both the firm and its shareholders. Consequently, shareholders may choose to delegate monitoring activities to lenders to the firm who not only have more experience monitoring the firm, but are also more informed compared to shareholders (Vashishtha 2014). However, if shareholders believe that a lender is using his monitoring efforts for personal gain to the detriment of shareholders' equity claim, shareholders demand increased disclosure from the firm. Accordingly, using instances of managers' issuance of earnings forecast, I find that managers of firms with dual-holders are more likely to issue earnings 
forecast following loan origination. These results are consistent with shareholders' increased scrutiny following dual-holder participation in a firm.

This paper complements and extends other studies that examine the influence of informed traders on the firm's price-informativeness and disclosure policy. In contrast, prior studies on dual-holders have focused mainly on dual-holders' influence on the agency conflict between shareholders and creditors. For example Chava, Wang, and Zou (2015) suggest that firms with dual-holders are more likely to be granted an unconditional waiver and do not experience a significant decrease in investment expenditures. Similarly, Lim, Minton, and Weisbach (2014) provide evidence that shareholders of a firm act as its lenders of last resort and thus demand a higher loan rate. However, no prior studies have examined the influence of dual-holders on the firms' overall information environment. This paper is the first empirical study to show that dualholders increases the overall market efficiency by causing prices to reflect the firm's underlying fundamental faster. Importantly, I show that dual-holder participation in a firm increases the demand for transparency by other investors. Thus, even though dual-holders extract rent from other shareholders by trading on material non-public information, they positively influence the overall information environment of the borrower by increasing the firm's price-informativeness and increasing the probability of managements forecast issuance.

My findings have important implications for investors and policymakers. First, this study sheds light on the importance of weighting the overall benefits versus the costs of informedtrading to the investors and capital market by the SEC and investors before enforcing insider trading rules and scrutiny of dual-holding institutions. Second, my results signify the importance of further research in this area and that the SEC and the Financial Accounting Standards Board 
(FASB) should consider allowing firms to set by-laws regarding what is considered prohibited insider trading instead.

The following section reviews important literature and develops testable hypotheses regarding the influence of dual-holders on the firm's information environment and disclosure quality. Section 10 and section 11 describe the research design and sample formation details. Section 12 presents the empirical results and section 13 concludes.

\section{Hypotheses Development}

Dual-holders, through their participation in the syndicated loan of the firm, have access to material information that is not available to other shareholders. As a result dual-holders should be considered informed investors. Extant literature that examines the informational advantage of lenders can be divided into two groups. The first group studies whether lenders use their access to additional information to more effectively monitor the firm (monitoring hypothesis). For example, Chava and Roberts (2008) show that lenders restrict a borrower's capital investment following financial covenant violations. Similarly, Vashishtha (2014) demonstrates that a borrower's discretionary disclosure is decreased following a covenant violation. The author argues that the change in the disclosure is the result of the firm's shareholders delegating costly monitoring to the firm's lenders following a covenant violation. The second group of literature examines whether syndicate participants use their information advantage to generate excess profits by trading in other markets, namely the secondary loan and equity markets (rentextraction hypothesis). For example, Bushman, Smith, and Wittenberg-Moerman (2010), find that in firms with syndicated loans, equity prices adjust faster to the arrival of new information. Peyravan (2016) finds that shareholders of a firm that participate in the firm's syndicated loans are able to generate risk-adjusted returns in excess of $6 \%$ in their trades in the short time between 
the syndicate origination date and the firm's next earnings announcement date. In contrast, the return from a simple buy and hold strategy during the same time period is not statistically different from zero. The author thus concludes that dual-holders use the information received from their participation in the syndicated loan to make informed trades in the firm's equity and generate excess returns.

Kyle (1985) is one the first theoretical studies that examines the market consequences of informed trading by describing a setting in which an informed investor strategically trades against the market-maker (and other less informed shareholders) to generate excess profits. In this model, the market-maker faces an adverse selection problem because they are trading with unidentified investors who are potentially more informed. As a result, the market-maker demands compensation by adjusting the bid-ask spread according to the level of informationasymmetry of a firm's investors (Glosten and Milgrom 1985). However as the informed-trader trades on his private information to generate profits, his private information is gradually reflected in the market price of the equity. Holden and Subrahmanyam (1992) extend the Kyle (1985) model of a single informed investor to include multiple competing informed traders and multiple periods in which the price of information asymmetry of a firm's equity is a function of the number of its informed investors. Thus, as the number of informed investors in a firm increases, private information is reflected in the price faster. Consistent with this model, in their empirical study Akins, Ng, and Verdi (2012) show that pricing of information asymmetry decreases as the number of informed investors in the firm increases. The authors explain that as the number of informed investors in a firm increases the price becomes more representative of the firm's underlying fundamentals, thus reducing the price of information asymmetry. 
In practice, identifying informed investors is not trivial. Institutional investors are the most common proxy for informed traders used in prior literature. For example Maffett (2012) finds that changes in institutional holding of a firm are positively associated with its future returns. The author also find that the relation between a firm's institutional holding and its future returns is more pronounced for opaque firms in a weak regulatory environment, where informed investors can maximize their returns on informed trades. Ke and Petroni (2004), following Bushee (2001), further narrow down these "informed" institutional investors to transient investors (i.e., investors with a short-term investment horizon) and find that such investors can predict a bad news break (a loss quarter after a string of earnings increases) at least one quarter in advance. Other studies instead focus on identifying firms with higher likelihood of having informed traders. For example Aboody and Lev (2000) suggest that insider trading is more prevalent in $R \& D$ intensive firms. More recent studies have been able to identify more innovative proxies for informed investors. Acharya and Johnson (2010) use the number of bidding entities in a leveraged buy-out as the proxy for insiders and show that the number of participants in the LBO is positively associated with abnormal returns and volume in their equity, bond, and CDS markets during the 5-day window immediately preceding the bid. ${ }^{19} \mathrm{Kim}$ et al. (2014) use firms with actively traded CDSs as those with a higher likelihood of informed trading. The authors hypothesize and empirically demonstrate that lenders to such firms are more likely to trade on inside information because they are able to shed their credit risk exposure via the CDS market.

In this study, I propose a novel measure of informed trader defined as institutional shareholders who simultaneously act as lenders to the firm (i.e., dual-holders). With the

\footnotetext{
${ }^{19}$ The authors however do not find any evidence on the association between the number of syndicated-loan participants to the LBO target and abnormal return and volume during the event period.
} 
increased participation of institutional investors in syndicated loans (previously limited to banking institutions), these dual-holders have emerged as a new group of informed investors due to their access to the borrower's more detailed and timely financial information. Furthermore, dual-holders are likely to trade on their private information and generate excess returns (Peyravan 2016). As dual-holders trade on firm-specific material non-public information, I expect the price to be adjusted to reflect such information more rapidly and thus the information uncertainty of the borrower to decrease following loan start date. The first hypothesis is stated in the alternative form as follows:

H1: Ex-post, dual-holders reduce a firm's information uncertainty.

I use several measures of information uncertainty to examine the influence of dualholders on the borrower, namely the firm's future earnings response coefficient (FERC) (Lundholm and Myers 2002, Tucker and Zarowin 2006), bid-ask spread during the earnings announcement period, and analyst forecast dispersion (Cheng, Dhaliwal, and Neamtiu 2011). As a robustness check, I also calculate the borrower's abnormal returns during the earnings announcement period following dual-holder participation (Bushman, Smith, and WittenbergMoerman 2010).

While dual-holders potentially increase the informativeness of the firm's equity price, it is not clear how they influence a firm's discretionary disclosure practices as measured by the firm's managers' decision to issue an earnings forecast. Voluntary disclosure of a firm is driven by several factors, namely (1) the manager's intent to reduce the information asymmetry between informed and uninformed investors (e.g., Lev and Penman 1990, Balakrishnan et al. 2014), (2) the investors' ability to detect misrepresentation (e.g., Rogers and Stocken 2005), and (3) the 
shareholders' demand for disclosure (e.g., Vashishtha 2014). Dual-holders could potentially influence each of these factors and consequently the firm's discretionary disclosure.

If dual-holders' participation in the market increases the information asymmetry among a firm's investors and thus the firm's information uncertainty, the manager will have a greater incentive to issue earnings forecasts in an effort to reduce the information gap between the firm's investors. In line with the above reasoning, Bushman, Smith, and Wittenberg-Moerman (2010) show that the management's earning forecast partially pre-empts the faster equity price discovery of informed trading. Alternatively, if dual-holders cause firm-specific information to be reflected in the equity prices of the firm more quickly, then shareholders are more likely to detect any misrepresentation in the manager's disclosure and the manager might be less willing to issue earnings forecast. Finally, it is not clear how dual-holders influence the other shareholders' demand for disclosure. If shareholders believe that dual-holders act as monitors of the firm, then they may choose to delegate costly monitoring activities to lenders and thus decrease the demand for managers' voluntary disclosure (Vashishtha 2014). However, if shareholders fear that dualholding is causing the lender(s) to forgo monitoring activities for personal gains at the expense of other shareholders then the shareholders' demand for disclosure could increase. Given the above discussion, the effect of dual-holding on a firm's discretionary disclosure policies is not clear. The second hypothesis is stated as follows:

H2A: Disclosure quality of a firm increases after dual-holder participation in that firm. H2B: Disclosure quality of a firm decreases after dual-holder participation in that firm. 


\section{Research Design}

I examine the association between dual-holder participation in the firm and information asymmetry, and in particular, whether dual-holders increase the information asymmetry. I estimate the information asymmetry for each firm using several measures, namely (1) the firm's future earnings response coefficient, (2) the change in the bid-ask spread during the three day period surrounding the earnings announcement date (event period), and (3) analyst forecast dispersion following dual-holder participation in the firm. I use a fixed-effect panel-data regression model to examine the change in each variable following dual-holder participation in the firm. Using this research design addresses some of the potential endogeneity concerns because each firm serves as its own control and thus mitigates the concern that the association between dual-holder participation and information asymmetry is due to an omitted firm characteristic.

\subsubsection{Measures of dual-holder participation}

Prior studies on informed investors have mainly used either the number of a firm's institutional investors or the percentage of the firm's shares held by institutional investors as the proxy for how informed the firm's investors are (e.g., Lehavy and Sloan 2008; Gompers and Metrick 2001). Institutional investors are considered more informed than other shareholders because (1) they are more likely to have access to the firm's material information that is not yet public, (2) they are able to process public information faster and more efficiently, and (3) they pay closer attention to the firm and its available information. However, as more recent studies point out, institutional investors are a noisy measure for informed investors and consequently attempt to refine the measure further. For example, Yan and Zhang (2007) find that among institutional investors, transient investors are better informed because the change in short-term 
institutional ownership better predicts the firm's future returns. Bushee and Goodman (2007) propose the size of the institutional investors' ownership in a firm, and Brav et al. (2008) and Massoud et al. (2011) use the institutional investors' type, namely whether it is a hedge fund or private equity fund, as the determinant for the institutional investors' informed status.

In this study I propose a novel measure of informed investor called "dual-holders" that is defined as shareholders that simultaneously act as lenders to the firm. To create this measure, I manually match each lender, as well as its parents and subsidiaries, to all mutual funds available in the Thomson-Reuter 13F database. A dual-holder is defined as a lender that also holds the firms' equity in the same year-quarter. This variable is set to 1 during the lifetime of the loan and is set back to 0 following the loan maturity date.

\subsubsection{Future earnings response coefficient}

If dual-holders trade on the firm's material non-public information, it is likely that both private and public information are incorporated into the firm's equity prices more quickly and thus the firm's price informativeness is increased following dual-holder participation. Following Lundholm and Myers (2002), I use the future earnings response coefficient (FERC) approach as the proxy for the firms' price informativeness. FERC for a firm is defined as follows:

$$
R_{t}=b_{0}+b_{1} E P S_{t-1}+b_{2} E P S_{t}+b_{3} E P S_{t 3}+b_{4} R_{t 3}+\varepsilon_{t},
$$

where $R_{t}$ is the ex-dividend stock return for fiscal quarter $t, E P S_{t-1}$ is earnings per share (EPS) excluding extraordinary items divided by the stock price at the beginning of the quarter for quarter $t-1, E P S_{t 3}$ is the sum of earnings per share for quarters $t+1$ to $t+3$, and $R_{t 3}$ is the annually compounded stock return for quarters $t+1$ to $t+3$. This equation states that the equity return in each quarter is equal to the sum of the unexpected earnings for quarter $t$ and the change in expectations during quarter $t$ about earnings in quarter $t+1$ (scaled by the equity 
price at the beginning of the quarter). ${ }^{20}$ Earnings levels in quarters $t$ and $t-1$ are used as the proxy for unexpected earnings. ${ }^{21}$ The change in the expected future earnings consists of an expected and an unexpected component: realized future earnings are used as the proxy for the expected component and future returns are used as the proxy for the unexpected component. Because revisions in expectations of future earnings are reflected in the coefficient relating the current earnings shock to current returns (Collins et al. 1994), $b_{2}$ (i.e., the ERC) is expected to be positive. The coefficient on future earnings (i.e., the FERC) is predicted to be positive because it estimates the informativeness of the price with respect to the firm's future earnings. ${ }^{22}$ The coefficient on $R_{t 3}$ is expected to be negative because a negative sign ensures that irrelevant components positively related to future returns (i.e., events occurring in future periods that affect future earnings) are removed from $E P S_{t 3}$, thus increasing the accuracy of the approximation of the changes in expectations of future earnings growth in period $t$.

In order to examine the effect of dual-holding on the informativeness of price with respect to future earnings, I modify the above equation by adding the indicator values for dualholding and its interactions with the existing independent variables as follows (Tucker and Zarowin 2006):

$$
\begin{array}{rl}
R_{t}=b_{0}+b_{1} E & P S_{t-1}+b_{2} E P S_{t}+b_{1} E P S_{t 3}+b_{4} R_{t 3}+c_{1} \text { DualHolder }_{t} \times E P S_{t-1} \\
& +c_{2} \text { DualHolder }_{t} \times E P S_{t}+c_{3} \text { DualHolder }_{t} \times E P S_{t 3} \\
& +c_{4} \text { DualHolder }_{t} \times R_{t 3}+\varepsilon_{t}
\end{array}
$$

\footnotetext{
${ }^{20}$ Please see Lundholm and Myers (2002) pages 812-814 for the detailed derivation of this result.

${ }^{21}$ If the coefficients on $E P S_{t-1}$ and $E P S_{t}$ are of approximately equal value but opposite signs, then the market assumes that earnings follow a random walk process. However if the coefficient on $E P S_{t-1}$ is zero, the market is treating the earnings as white noise.

${ }^{22}$ As Collins et al. (1994) explain, the positive correlation between future earnings and current returns occurs due to (1) delays in recognizing asset values and (2) accruals accounting.
} 
where DualHolder ${ }_{t}$ is an indicator variable that equals 1 if the firm has a dual-holder in that year-quarter and is set to 0 otherwise. All other variables are as defined previously. The coefficient of interest is $c_{3}$ because it estimates the influence of dual-holding on the informativeness of the price with respect to the firm's future earnings. If this coefficient is positive and statistically significant, I can conclude that the dual-holders trade on material nonpublic information that is relevant to the firm's future earnings and cause realized future earnings to be reflected in current returns. In contrast, if dual-holders trade only on current publicly available information, then $c_{3}$ should be close to zero.

\subsubsection{Bid-ask spread}

A common proxy for a firm's information asymmetry used in prior studies is the bid-ask spread. If dual-holders trade on material non-public information prior to the earnings announcement date, then the information is reflected in the price prior to that date. Consequently, dual-holders potentially reduce the information asymmetry across investors and cause the bidask spread to decrease around earnings announcement. I use the earnings announcement period to examine the change in firms' information environment because (1) earnings announcement dates are specific information events that occur for all firms, and (2) using the earning announcement date allows me to control for the firm's pre-announcement level of disclosure (Bushee et al. 2010). I define the earnings announcement period as the three trading days surrounding the earnings announcement day (days -1 to +1 ). To control for the differences in bid-ask spread due to firm-specific characteristics, I use non-event days, defined as $t-55$ to $t-11$ trading days before the earnings announcement date, as the benchmark bid-ask spread. As a robustness check, I also investigate the change in the pre-earnings announcement period. I define pre-earnings announcement period as trading day from the loan start date or 10 days 
before the earnings announcement date (which ever one is later) to 2 days prior to the earnings announcement date. Following to Naranjo (2015), the change in a firm's information asymmetry in each time period is defined as:

$$
\Delta \text { Spread }_{\text {pre-event }}=\frac{\text { Spread }_{\text {pre-event }}-\text { Spread }_{\text {non-event }}}{\text { Spread }_{\text {non-event }}}
$$

and

$$
\Delta \text { Spread }_{\text {event }}=\frac{\text { Spread }_{\text {event }}-\text { Spread }_{\text {non-event }}}{\text { Spread }_{\text {non-event }}} .
$$

Spread is defined as the difference between the closing bid and ask prices deflated by the daily closing price of the security. I eliminate observations where the bid-ask spread is negative or if the difference between the bid and ask is greater than the price. I also compare the above measures of the change in bid-ask spread to the same measure two quarters before the dualholder participation. Using this research design, each firm acts as its own control, thus mitigating the concern that an omitted variable is driving the association between dual-holding and changes in the firm's information asymmetry.

\subsubsection{Cumulative abnormal returns}

If dual-holders trade on material non-public information in a firm, then abnormal equity returns during this time period will decrease or disappear because the firm specific information will mostly be reflected in the price of the firm's equity before the earnings announcement date (Bushman, Smith, and Wittenberg-Moerman 2010). Thus as an additional test I also examine how a firm's cumulative abnormal return during the 3-day earnings announcement period is affected following dual-holder participation. I measure a firm's risk-adjusted abnormal returns during the earnings announcement period as the difference between its actual and expected 
returns. A firm's expected return using the Fama and French (1993) three-factor model is calculated as follows:

$$
r_{i t}=r_{f}+\hat{\alpha}_{1}\left(r_{m t}-r_{f}\right)+\hat{\alpha}_{2} S M B_{t}+\hat{\alpha}_{3} H M L_{t}+\varepsilon_{i t}
$$

where $r_{m t}$ is the market factor return on day $t$, and $r_{i t}$ is the daily return of firm $i$ on day $t$. $S M B_{t}$ and $H M L_{i}$ are the daily factor-mimicking portfolio returns from Ken French's website. ${ }^{23}$ The coefficients for each return equation are estimated using the firm's daily returns in the 100 days prior to the earnings announcement date. I then use the coefficients obtained from each regression during the estimation period to calculate the predicted return for each firm on each day during the event period. The risk-adjusted abnormal (or excess) return is then measured as the difference between the actual and predicted return. The cumulated abnormal return $(C A R)$ is the sum of the abnormal returns during the event period. As a robustness check, I also calculate the buy-and-hold abnormal returns (BHAR) during the event period. ${ }^{24}$

\section{Data and Summary Statistics}

To identify dual-holders, I follow the methodology detailed in Peyravan (2016). I use the 13f filings from the Thomson Reuters Institutional Ownership database and identify the fund(s) that correspond to each lender (including its parent and all subsidiaries) in the DealScan database by searching Bloomberg and BusinessWeek online resources, as well as firms' SEC filings. An institutional investor is identified as a dual-holder if it lends to a firm while holding its equity (either directly or through its parent or subsidiaries) in the same year-quarter as the loan start date. I match borrowers to CRSP/COMPUSTAT following Chava and Roberts (2008) and obtain the GVKEY for each borrower. Using the GVKEY, I construct borrower level control variables

\footnotetext{
${ }^{23} \mathrm{http}: / / \mathrm{mba} . t u c k . d a r t m o u t h . e d u / p a g e s / f a c u l t y /$ ken.french/Data_Library/f-f_factors.html

${ }^{24}$ BHAR employs geometric returns rather than arithmetic returns in calculating the overall return over the event period of interest, thus using BHAR allows for compounding whereas the CAR does not.
} 
from the CRSP/COMPUSTAT, and the Thomson Reuters databases. Analyst data is retrieved form the $\mathrm{I} / \mathrm{B} / \mathrm{E} / \mathrm{S}$ database. I obtain the syndicate-specific information from the DealScan database from January 2007 to June 2014. The bid-ask spread is calculated using the daily firm market data from the CRSP database.

\section{Empirical Analyses}

\subsection{Dual-holders' influence on the borrowers' information uncertainty}

First, I examine how dual-holders affect the firm's bid-ask spread. Table 14 presents the univariate analyses of changes in the firm's bid-ask spread before and during the event period. The bid-ask spread during the pre-event and event periods are compared to the firm's bid-ask spread during the non-event period in order to control for differences between firm's other characteristics that influence its bid-ask spread. While as expected, the bid-ask spread increases for all firms during the earnings announcement period, the increase is much smaller in firms with non-bank dual-holders. A similar pattern is observed for changes in the bid-ask spread in the preevent time period.

Next I examine how dual-holder participation influences the liquidity of borrowers' shares during the earnings announcement period, as well as in the pre-event period. The univariate analyses results in Table 15 suggest that dual-holder participation increases the liquidity in the borrower's shares during the earnings announcement period (column 1), while the opposite effect is observed for commercial banking dual-holders and firms without dual-holders. Similarly, the decrease in liquidity during the pre-earnings announcement period is smaller for firms with non-bank dual-holders. The results in this table are consistent with the hypothesis that dual-holder participation in a firm decreases the information asymmetry among the firm's investors as prices reflect the firm-specific information more quickly. 
As an additional analysis, I also examine how cumulative abnormal returns change during the earnings announcement period after dual-holder participation. Consistent with the first hypothesis, as well as results in the previous two tables, I find that abnormal return during the earnings announcement period is not statistically different from zero for firms with dual-holders. Consistent with prior studies, firms with bank dual-holders or without dual-holder participation have positive and statistically significant abnormal returns during the 3-day earnings announcement window. Overall, the results above point to the decrease in the information asymmetry between the investors of firms with dual-holders as a result of increase in the informativeness of the equity price of such firms.

Next, I examine how dual-holders influence the future earnings response coefficient (FERC) of the borrowing firm following dual-holding. Table 17 presents the results of the FERC regression for firms with non-bank (column 2) and bank (column 3) dual-holders. If dualholders' trades on the firm's material non-public information causes private and public information to be reflected more quickly into the firm's equity prices, the firm's price informativeness will increase. The coefficient of interest in this regression is the one of the interaction of dual-holder and the firm's 3-quarters-ahead EPS. The first column presents the results of the original FERC regression. As expected, in column (1) the coefficients on $E P S_{t-1}$ and $R_{t 3}$ are negative while the ones on $E P S_{t}$ and $E P S_{t 3}$ are positive and significant. In Column (2), the coefficient on the interaction variable of interest (Dual Holder $\left.\times E P S_{t 3}\right)$ is positive and significant, while in column (3) it is negative. The results in this table demonstrate that NCB dual-holders increase the informativeness of the firm's equity price.

In the next step, I measure how a firm's bid-ask spread changes during the earnings announcement period following dual-holder participation using a fixed-effect panel-data 
regression analyses. ${ }^{25}$ The results are displayed in Table 18 . Coefficients on indicators variables for non-bank and bank dual-holders suggest that there is no statistically significant changes in the bid-ask spread of firms with bank dual-holders while the bid-ask spread of firms with non-bank dual-holders decreases during the earnings announcement period (column 2).

In Table 19, I test the influence of dual-holders on bid-ask spread during the earnings announcement period. The results are similar to those in Table 15 and suggest that dual-holders reduce the bid-ask spread during the earnings announcement period, compared to firms without dual-holder participation. This result in consistent with market makers demanding a lower spread as prices are now more reflective of the firm-specific information, thus reducing the information asymmetry between the market maker and the more informed investors.

I examine the influence of dual-holders on analysts' forecast dispersion in Table 20. The results suggest that consistent with dual-holders reducing the firm's information asymmetry and increasing the information quality of the firm, non-bank dual-holder participation in a firm reduces the firm's analyst forecast dispersion in the following quarter.

As a robustness test, I analyse the effect of dual-holders on the firm's abnormal returns during the earnings announcement period. The results in Table 21 suggest that non-bank dual-holders are associated with statistically a significant decrease in the risk-adjusted abnormal returns during the 3-days surrounding the earnings announcement date. Furthermore, I do not observe the same effect for bank dual-holders. In summary, the results on the univariate analyses, as well as the multivariate analyses, are consistent with the first hypothesis and strongly suggest that dual-holder participation in a firm increases the informativeness of the borrower's equity price ex-post.

\footnotetext{
${ }^{25}$ Including year-fixed effects effectively transforms this model into a two-way fixed-effect model.
} 


\subsection{Dual-holders' influence on the borrowers' disclosure quality}

In this section I study the influence of dual-holders on the firm's disclosure quality as measured by instances of the firm's managers' earnings forecast issuance. Table 22 presents the results of a logit fixed effect panel data regressions using instances of managements' issuance of earnings forecast as the dependent variable. Forecast $t_{t+1}$ equals 1 if the manager issues an earnings forecast in the next quarter and 0 otherwise. The effect of NCB dual-holding is positive and significant particularly in the second quarter following the dual-holder participation in the loan and suggest that NCB dual-holders increase the instances of managers' forecast issuance in the next quarter. The results in this section suggest consistent with the second hypothesis, nonbank dual-holders improve the information environment of firms they participate in by increasing the investors' demand for more disclosure.

\section{Conclusion}

In this paper I find that lenders who are also shareholders of a firm not only influence the lenders' information uncertainty, but also disclosure quality ex-post. Consequently, my findings are important for not only market participants, but also policymakers in the examination of the overall benefits versus the costs of insider trading to the investors and capital market. 


\section{REFERENCES}

Abarbanell, Jeffery S., Brian J. Bushee, and Jana Smith Raedy. 2003. "Institutional Investor Preferences and Price Pressure: The Case of Corporate Spin-Offs." The Journal of Business 76 (2): 233-261.

Aboody, David, and Baruch Lev. 2000. "Information Asymmetry, R\&D, and Insider Gains." The Journal of Finance 55 (6): 2747-2766.

Acharya, Viral V., and Timothy C. Johnson. 2010. "More Insiders, More Insider Trading: Evidence from Private-Equity Buyouts." Journal of Financial Economics 98 (3) (December): 500-523.

Aghion, Philippe, and Patrick Bolton. 1992. "An Incomplete Contracts Approach to Financial Contracting." Review of Economic Studies 59: 473-494.

Akins, Brian K., Jeffrey Ng, and Rodrigo S. Verdi. 2012. "Investor Competition over Information and the Pricing of Information Asymmetry." The Accounting Review 87 (1) (January): 35-58.

Armstrong, Christopher S., John E. Core, Daniel J. Taylor, and Robert E. Verrecchia. 2011. "When Does Information Asymmetry Affect the Cost of Capital?" Journal of Accounting Research 49 (1) (March 14): 1-40.

Balakrishnan, Karthik, Mary Brooke Billings, Bryan T. Kelly, and Alexander Ljungqvist. 2014. "Shaping Liquidity: On the Causal Effects of Voluntary Disclosure." The Journal of Finance LXIX (5).

Bharath, Sreedhar T., Jayanthi Sunder, and Shyam V. Sunder. 2008. "Accounting Quality and Debt Contracting." The Accounting Review 83 (1): 1-28.

Brav, Alon, Wei Jiang, Frank Partnoy, and Randall Thomas. 2008. "Hedge Fund Activism, Corporate Governance, and Firm Performance." The Journal of Finance LXIII (4): 17291775.

Brown, Stephen J., and Jerold B. Warner. 1980. "Measuring Security Price Performance." Journal of Financial Economics 8: 205-258.

Bushee, Brian J. 2001. "Do Institutional Investors Prefer Near-Term Earnings over Long-Run Value?" Contemporary Accounting Research 18 (2): 207-246.

Bushee, Brian J., and Theodore H. Goodman. 2007. "Which Institutional Investors Trade Based on Private Information about Earnings and Returns?" Journal of Accounting Research 45 (2): 289-321.

Bushman, Robert M., Abbie J. Smith, and Regina Wittenberg-Moerman. 2010. "Price Discovery and Dissemination of Private Information by Loan Syndicate Participants." Journal of Accounting Research 48 (5) (December 19): 921-972.

Chava, Sudheer, and Michael R Roberts. 2008. "How Does Financing Impact Investment? The Role of Debt Covenants." The Journal of Finance LXIII (5): 2085-2121.

Chava, Sudheer, Rui Wang, and Hong Zou. 2015. "Covenants, Creditors' Simultaneous Equity Holdings, and Firm Investment Policies."

Cheng, Mei, Dan S. Dhaliwal, and Monica Neamtiu. 2011. "Asset Securitization, Securitization Recourse, and Information Uncertainty." Accounting Review 86 (2): 541-568.

Christensen, Hans B., and Valeri V. Nikolaev. 2012. "Capital Versus Performance Covenants in Debt Contracts." Journal of Accounting Research 50 (1): 75-116.

Collins, Daniel W., S. P. Kothari, Jay Shanken, and Richard G. Sloan. 1994. "Lack of Timeliness and Noise as Explanations for the Low Contemporaneuos Return-Earnings Association." 
Journal of Accounting and Economics 18 (3): 289-324.

Dechow, Patricia, and Ilia D. Dichev. 2002. "The Quality of Accruals Earnings: The Role of Estimation Errors." The Accounting Review 77: 35-59.

Dechow, Patricia, Weili Ge, and Catherine Schrand. 2010. "Understanding Earnings Quality: A Review of the Proxies, Their Determinants and Their Consequences." Journal of Accounting and Economics 50 (2-3) (December): 344-401.

DeFond, Mark L. 2010. "Earnings Quality Research: Advances, Challenges and Future Research." Journal of Accounting and Economics 50 (2-3): 402-409.

Dichev, Ilia D., and Douglas J. Skinner. 2002. "Large-Sample Evidence on the Debt Covenant Hypothesis." Journal of Accounting Research 40 (4) (September): 1091-1123.

Easley, David, and Maureen O'Hara. 2004. "Information and the Cost of Capital." The Journal of Finance LIX (4): 1553-1583.

Ecker, Frank, Jennifer Francis, Irene Kim, Per M Olsson, and Katherine Schipper. 2006. "A Returns-Based Representation of Earnings Quality." The Accounting Review 81 (4): 749780.

Fama, Eugene F., and Kenneth R. French. 1993. "Common Risk Factors in the Returns on Stocks and Bonds." Journal of Financial Economics (33): 3-56.

Fang, Lily, Victoria Ivashina, and Josh Lerner. 2013. "Combining Banking with Private Equity Investing.” Review of Financial Studies 26 (9) (June 7): 2139-2173.

Francis, Jennifer, Ryan LaFond, Per Olsson, and Katherine Schipper. 2005. "The Market Pricing of Accruals Quality.” Journal of Accounting and Economics 39 (2): 295-327.

Francis, Jennifer, Dhananjay Nanda, and Per Olsson. 2008. "Voluntary Disclosure, Earnings Quality, and Cost of Capital." Journal of Accounting Research 46 (1) (January 2): 53-99.

Frankel, Richard M, Marilyn F Johnson, and Karen K Nelson. 2002. "The Relation between Auditor's Fees for Nonaudit Services and Earnings Management." The Accounting Review 77-Supple (2002): 71-105.

Glosten, Lawrence R., and Paul R. Milgrom. 1985. "Bid, Ask and Transaction Prices in a Specialist Market with Heterogeneously Informed Traders." Journal of Financial Economics 14 (1): 71-100.

Gompers, Paul A., and Andrew Metrick. 2001. "Institutional Investors and Equity Prices." Quarterly Journal of Economics 116 (1): 229-259.

Holden, Craig W., and Avanidhar Subrahmanyam. 1992. "Long-Lived Private Information and Imperfect Competition." The Journal of Finance 47 (1): 247-270.

Ivashina, Victoria, and Zheng Sun. 2011. "Institutional Stock Trading on Loan Market Information." Journal of Financial Economics 100 (2) (May): 284-303.

James, Christopher. 1987. "Some Evidence on the Uniqueness of Bank Loans." Journal of Financial Economics 19 (2): 217-235.

James, Christopher, and Peggy Wier. 1990. "Borrowing Relationships, Intermediation, and the Cost of Issuing Public Securities.” Journal of Financial Economics 28 (1-2): 149-171.

Jensen, Michael C., and William H. Meckling. 1976. "Theory of the Firm: Managerial Behavior, Agency Costs and Ownership Structure." Journal of Financial Economics 3: 305-360.

Jiang, Wei, Kai Li, and Pei Shao. 2010. "When Shareholders Are Creditors: Effects of the Simultaneous Holding of Equity and Debt by Non-Commercial Banking Institutions." Review of Financial Studies 23 (10) (August 26): 3595-3637.

Ke, Bin, and Kathy Petroni. 2004. "How Informed Are Actively Trading Institutional Investors? Evidence from Their Trading Behavior before a Break in a String of Consecutive Earnings 
Increases." Journal of Accounting Research 42 (5) (December): 895-927.

Kim, Jae B., Pervin K. Shroff, Dushyantkumar Vyas, and Regina Wittenberg Moerman. 2014. "Active CDS Trading and Managerss Voluntary Disclosure." SSRN Electronic Journal 3 (2).

Kothari, S.P., Andrew J. Leone, and Charles E. Wasley. 2005. "Performance Matched Discretionary Accrual Measures." Journal of Accounting and Economics 39 (1) (February): 163-197.

Kyle, Albert S. 1985. "Continuous Auctions and Insider Trading." Econometrica 53 (6): 13151335.

Lambert, Richard. 2001. "Contracting Theory and Accounting." Journal of Accounting and Economics 32: 3-87.

Lambert, Richard, Christian Leuz, and Robert E. Verrecchia. 2007. "Accounting Information, Disclosure, and the Cost of Capital." Journal of Accounting Research 45 (2) (May): 385420.

Lehavy, Reuven, and Richard G. Sloan. 2008. "Investor Recognition and Stock Returns." Review of Accounting Studies 13 (2-3) (January 9): 327-361.

Leland, Hayne E. 1998. "Agency Costs, Risk Management, and Capital Structure.” The Journal of Finance 53 (4): 1213-1243.

Lev, Baruch, and Stephen H Penman. 1990. "Voluntary Forecast Disclosure, Nondisclosure, and Stock Prices." Journal of Accounting Research 28 (1): 49-76.

Lim, Jongha. 2011. "Three Essays on the Effect of Alternative Investors on Corporate Finance."

Lim, Jongha, Bernadette a. Minton, and Michael S. Weisbach. 2014. "Syndicated Loan Spreads and the Composition of the Syndicate." Journal of Financial Economics 111 (1) (January): 45-69.

Lundholm, Russell, and Linda a Myers. 2002. "Bringing the Future Forward: The Effect of Disclosure on the Returns-Earnings Relation.” Journal of Accounting Research 40 (3): 809839.

Maffett, Mark. 2012. "Financial Reporting Opacity and Informed Trading by International Institutional Investors." Journal of Accounting and Economics 54 (2-3) (October): 201-220.

Massoud, Nadia, Debarshi Nandy, Anthony Saunders, and Keke Song. 2011. "Do Hedge Funds Trade on Private Information? Evidence from Syndicated Lending and Short-Selling." Journal of Financial Economics 99 (3) (March): 477-499.

McNichols, Maureen F. 2002. "The Quality of Accruals and Earnings: The Role of Accrual Estimation Errors: Discussion." The Accounting Review 77: 61-69.

McNichols, Maureen F., and Stephen R. Stubben. 2008. "Does Earnings Management Affect Firms' Investment Decisions?" The Accounting Review 83 (6) (November): 1571-1603.

Naranjo, Patricia. 2015. "How Does the Information Environment Affect Information Asymmetry around Earnings Announcements?"

Nini, Greg, David C. Smith, and Amir Sufi. 2009. "Creditor Control Rights and Firm Investment Policy.” Journal of Financial Economics 92 (3) (June): 400-420.

- 2012. "Creditor Control Rights, Corporate Governance, and Firm Value." Review of Financial Studies 25 (6): 1713-1761.

Parrino, Robert, and Michael S. Weisbach. 1999. "Measuring Investment Distortions Arising from Stockholder-bondholder Conflicts." Journal of Financial Economics 53 (1): 3-42.

Peyravan, Leila. 2016. "Financial Reporting Quality and Dual- Holding of Debt and Equity."

Rajgopal, Shiva, and Mohan Venkatachalam. 2011. "Financial Reporting Quality and 
Idiosyncratic Return Volatility." Journal of Accounting and Economics 51: 1-20.

Rogers, Jonathan L., and Phillip C. Stocken. 2005. "Credibility of Management Forecasts." Accounting Review 80 (4): 1233-1260.

Skaife, Hollis A., David Veenman, and Daniel Wangerin. 2013. "Internal Control over Financial Reporting and Managerial Rent Extraction: Evidence from the Profitability of Insider Trading." Journal of Accounting and Economics 55 (1): 91-110.

Smith, Clifford W., and Jerold B. Warner. 1979. "On Financial Contracting-An Analysis of Bond Convenants." Journal of Financial Economics 7 (2): 117-161.

Srinidhi, Bin N., and Ferdinand A. Gul. 2007. "The Differential Effects of Auditors' Nonaudit and Audit Fees on Accrual Quality." Contemporary Accounting Research 24 (2): 595-629.

Stubben, Stephen R. 2010. "Discretionary Revenues as a Measure of Earnings Management." The Accounting Review 85 (2) (March): 695-717.

Sufi, Amir. 2007. "Information Asymmetry and Financing Arrangements: Evidence from Syndicated Loans." The Journal of Finance LXII (2): 629-668.

Tucker, Jennifer W, and Paul A Zarowin. 2006. "Does Income Smoothing Improve Earnings Informativeness?" The Accounting Review 81 (1): 251-270.

Vashishtha, Rahul. 2014. "The Role of Bank Monitoring in Borrowers' Discretionary Disclosure: Evidence from Covenant Violations." Journal of Accounting and Economics 57 (2-3): 176-195.

Verrecchia, Robert E. 1980. "The Rapidity of Price Adjustments to Information." Journal of Accounting and Economics (2): 63-92.

Wittenberg-Moerman, Regina. 2009. "The Impact of Information Asymmetry on Debt Pricing and Maturity."

Yan, Xuemin Sterling, and Zhe Zhang. 2007. "Institutional Investors and Equity Returns: Are Short-Term Institutions Better Informed?” The Review of Financial Studies 22 (2). 


\begin{tabular}{|c|c|}
\hline Variable & Description \\
\hline$C A$ & $\begin{array}{l}\text { Total current accruals, measured as the change in non-cash } \\
\text { current assets minus the change in current non-interest bearing } \\
\text { liabilities, scaled by lagged total assets. }\end{array}$ \\
\hline$O C F$ & $\begin{array}{l}\text { Cash flow from operations measured as the sum of net income, } \\
\text { depreciation and amortization and change in current liabilities, } \\
\text { minus the change in current assets, scaled by lagged total assets. }\end{array}$ \\
\hline$\Delta R e v$ & Change in annual revenues scaled by lagged total assets \\
\hline$P P E$ & Property, plant, and equipment scaled by lagged total assets. \\
\hline TAcc & $\begin{array}{l}\text { Total accruals, measured as the change in non-cash current assets } \\
\text { minus the change in current non-interest bearing liabilities, } \\
\text { minus depreciation and amortization expense, scaled by lagged } \\
\text { total assets. }\end{array}$ \\
\hline$R O A$ & Net income divided by total assets \\
\hline$F R Q$ & $\begin{array}{l}\text { The absolute value of the standard deviation of the residual from } \\
\text { the regression following Dechow and Dichev (2002) multiplied } \\
\text { by }-1 \text {. }\end{array}$ \\
\hline Inst. ownership & $\begin{array}{l}\text { Log of } 1+\text { total institutional ownership in the firm divided by } \\
\text { total shares outstanding. }\end{array}$ \\
\hline Market Value & $\begin{array}{l}\text { Total value of the equity of the firm (millions) calculated as } \\
\text { share price at the end of the calendar year multiplied by the } \\
\text { number of shares }\end{array}$ \\
\hline Z-score & $\begin{array}{l}\text { Altman's Z-score calculated as } \\
3.3 \mathrm{EBIT}+0.99 \mathrm{Rev}+0.6 \mathrm{MarketCap}+1.2 \mathrm{WC}+1.4 \mathrm{Re}, \text { all scaled by } \\
\text { total assets. }\end{array}$ \\
\hline $\operatorname{Re}$ & Retained earnings \\
\hline Analyst & $\begin{array}{l}\text { Total number of the firm's analysts, calculated as } 1+\log \text { of the } \\
\text { number of analysts from IBES. }\end{array}$ \\
\hline Disagree & $\begin{array}{l}\text { Standard deviation of analysts' one-year EPS forecast divided by } \\
\text { the average forecasted EPS. }\end{array}$ \\
\hline Accuracy & $\begin{array}{l}\text { Average of the absolute value of analysts' error (predicted minus } \\
\text { actual value) as a percentage of actual EPS, multiplied by }-1 \text {. }\end{array}$ \\
\hline $\log ($ Facility $)$ & Natural $\log$ of the facility amount \\
\hline Maturity & Syndicated loan maturity measured in months \\
\hline
\end{tabular}




\begin{tabular}{|c|c|}
\hline Variable & Description \\
\hline Secured Flag & Indicator variable that equals 1 if the syndicated loan is secured \\
\hline Revolver Flag & $\begin{array}{l}\text { Indicator variable that equals } 1 \text { if the syndicated loan is a } \\
\text { revolver }\end{array}$ \\
\hline LBO Flag & $\begin{array}{l}\text { Indicator variable that equals } 1 \text { if the primary purpose of the loan } \\
\text { is an LBO }\end{array}$ \\
\hline Log(Number of Lenders) & Log of the number of lenders in the syndicate \\
\hline Asset & Total asset value of the firm (millions) \\
\hline Market Value & $\begin{array}{l}\text { Number of shares outstanding multiplied by the share price at the } \\
\text { end of the calendar year }\end{array}$ \\
\hline Illiquidity & $\begin{array}{l}\text { Log of Amihud (2002) illiquidity measure, calculated as the } \\
\text { annual average of the monthly equity return divided by monthly } \\
\text { dollar trading volume, multiplied by } 1000 \text {. It can be interpreted } \\
\text { as the daily price response associated with one dollar of trading } \\
\text { volume, thus serving as a rough measure of price impact }\end{array}$ \\
\hline Leverage & Long-term debt scaled by total assets \\
\hline$B M$ & $\begin{array}{l}\text { Book to market ratio calculated as total assets divided by the sum } \\
\text { of market value of equity and total debt }\end{array}$ \\
\hline Industry Adjusted Return & Annual equity return adjusted by the industry return \\
\hline Loan Cost & The cost of the loan measured as the spread in excess of LIBOR \\
\hline Bad News & Indicator variable that equals 1 if the equity return is negative \\
\hline Loss Firm & $\begin{array}{l}\text { Indicator variable that equals } 1 \text { if the firm has experienced a loss } \\
\text { as net income }\end{array}$ \\
\hline$\Delta$ Sales-yr & The firm's sales growth over the past 3 years \\
\hline Fcast & $\begin{array}{l}\text { Indicator variable that equals } 1 \text { if the manager provides earnings } \\
\text { forecast from the First Call database and } 0 \text { otherwise. If the } \\
\text { firm's management has never provided an earnings forecast the } \\
\text { variable is set to null }\end{array}$ \\
\hline$\Delta$ LogAssets & Log change in assets \\
\hline$\triangle \log P P E$ & Log change in log plant, property and equipment \\
\hline$\triangle C A P E X$ & Change in capital expenditure, scaled by average total assets \\
\hline$\Delta D e b t$ & Log change of total debt \\
\hline
\end{tabular}




\begin{tabular}{ll}
\hline Variable & Description \\
\hline$\Delta$ Cash & $\begin{array}{l}\text { Change in total cash and short-term securities, scaled by average } \\
\text { total assets }\end{array}$ \\
$\Delta S / h$ Payout & Change in the sum of dividends and purchase of equity, scaled \\
by average total assets & Change in the operating cash flow, scaled by average total assets \\
$\Delta C F O$ & Change in log sales \\
$\Delta$ LogSales & Change in SG\&A expense, scaled by average total assets \\
$\Delta S G A$ & $\begin{array}{l}\text { Number of capital covenants divided by the sum of the number } \\
\text { of capital and performance covenants }\end{array}$ \\
Cap-Cov ratio & $\begin{array}{l}\text { Number of performance covenants divided by the sum of the } \\
\text { number of capital and performance covenants }\end{array}$ \\
Indicator variable that equals 1 if an investor holds the equity of \\
Lead-lender Reputation
\end{tabular}




\section{Appendix 2: Variable definitions for Chapter 2}

Variable
Average Spread
$\Delta$ Spread $_{\text {pre-event }}(\%)$
$\Delta$ Spread $_{\text {event }}(\%)$
$R_{t 3}$
EPS $_{t 3}$
Dispersion
ROA
FRQ

Inst. ownership

Market Value

Z-score

Analyst

Disagree

Accuracy

$\log$ (Facility)
Description

Daily average of spread, calculated as the difference between the bid and ask price divided by the closing price, multiplied by 100 .

Percent change in the spread in the pre-event period ( 2 to 11 days before the earnings announcement day) from the non-event period (11 to 35 days prior to the earnings announcement date)

Percent change in the spread in the event period (3 days surrounding the earnings announcement day) to non-event period (11 to 35 days prior to the earnings announcement date)

The compounded stock return for quarters $t+1$ to $t+3$

The sum of earnings per share for quarters $t+1$ to $t+3$

One-year ahead analyst forecast dispersion measured in the second month of quarter $t$ and calculated as the standard deviation of forecasts scaled by mean of forecasts from the IBES summary file.

Net income divided by total assets, industry adjusted

The absolute value of the standard deviation of the residual from the regression following Dechow and Dichev (2002) multiplied by -1 .

Log of $1+$ total institutional ownership in the firm divided by total shares outstanding.

Total value of the equity of the firm (millions) calculated as share price at the end of the calendar year multiplied by the number of shares

Altman's Z-score calculated as

3.3EBIT+0.99Rev+0.6MarketCap+1.2WC+1.4Re, all scaled by total assets.

Total number of the firm's analysts, calculated as $1+\log$ of the number of analysts from IBES.

Standard deviation of analysts' one-year EPS forecast divided by the average forecasted EPS.

Average of the absolute value of analysts' error (predicted minus actual value) as a percentage of actual EPS, multiplied by -1 .

Natural $\log$ of the facility amount 


\begin{tabular}{|c|c|}
\hline Variable & Description \\
\hline Maturity & Syndicated loan maturity measured in months \\
\hline Secured Flag & Indicator variable that equals 1 if the syndicated loan is secured \\
\hline Revolver Flag & $\begin{array}{l}\text { Indicator variable that equals } 1 \text { if the syndicated loan is a } \\
\text { revolver }\end{array}$ \\
\hline LBO Flag & $\begin{array}{l}\text { Indicator variable that equals } 1 \text { if the primary purpose of the loan } \\
\text { is an LBO }\end{array}$ \\
\hline Log(Number of Lenders) & Log of the number of lenders in the syndicate \\
\hline Asset & Total asset value of the firm (millions) \\
\hline Market Value & $\begin{array}{l}\text { Number of shares outstanding multiplied by the share price at the } \\
\text { end of the calendar year }\end{array}$ \\
\hline Illiquidity & $\begin{array}{l}\text { Log of Amihud (2002) illiquidity measure, calculated as the } \\
\text { quarterly average of the daily equity return divided by dollar } \\
\text { trading volume, multiplied by } 1000 \text {. It can be interpreted as the } \\
\text { price response associated with one dollar of trading volume, thus } \\
\text { serving as a rough measure of price impact }\end{array}$ \\
\hline Leverage & Long-term debt scaled by total assets \\
\hline$B M$ & $\begin{array}{l}\text { Book to market ratio calculated as total assets divided by the sum } \\
\text { of market value of equity and total debt }\end{array}$ \\
\hline Loan Cost & The cost of the loan measured as the spread in excess of LIBOR \\
\hline Bad News & Indicator variable that equals 1 if the equity return is negative \\
\hline Loss Firm & $\begin{array}{l}\text { Indicator variable that equals } 1 \text { if the firm has experienced a loss } \\
\text { as net income }\end{array}$ \\
\hline$\Delta$ Sales-yr & The firm's sales growth over the past 3 years \\
\hline Fcast & $\begin{array}{l}\text { Indicator variable that equals } 1 \text { if the manager provides earnings } \\
\text { forecast from the First Call database and } 0 \text { otherwise. If the } \\
\text { firm's management has never provided an earnings forecast the } \\
\text { variable is set to null }\end{array}$ \\
\hline High Dual-Holding & $\begin{array}{l}\text { Indicator variable that equals } 1 \text { if the total equity-holding of } \\
\text { dual-holders' as a percentage of the total shares outstanding is in } \\
\text { the top decile of the sample }\end{array}$ \\
\hline
\end{tabular}


Figure 1-Chapter 1: Dual-holder participation in loans

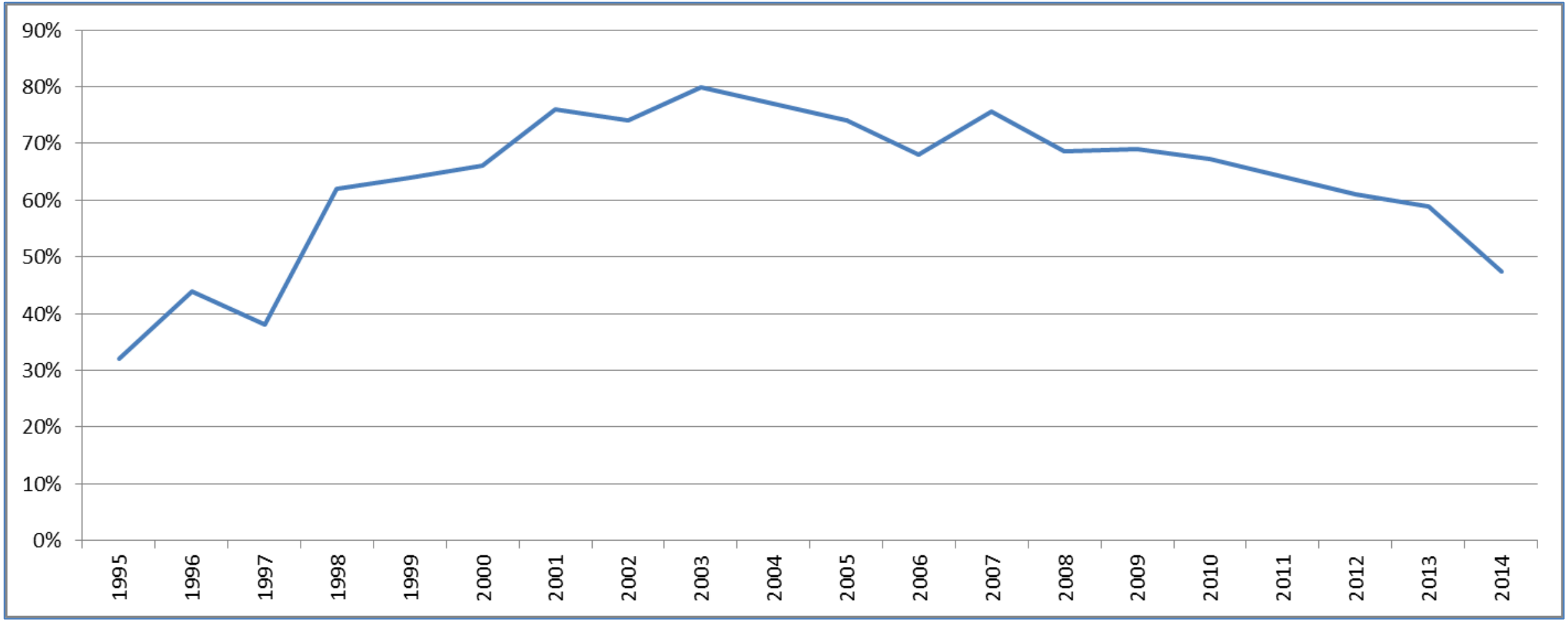

This graph displays the institutional investor participation in the syndicated loan market as the percentage of total dollar amount of loans issued. The data on institutional investor and dual-holder participation from 1995 to 2005 is from Jiang, Li, and Shao (2010). 
Figure 2-Chapter 1: Histogram of the number of event days
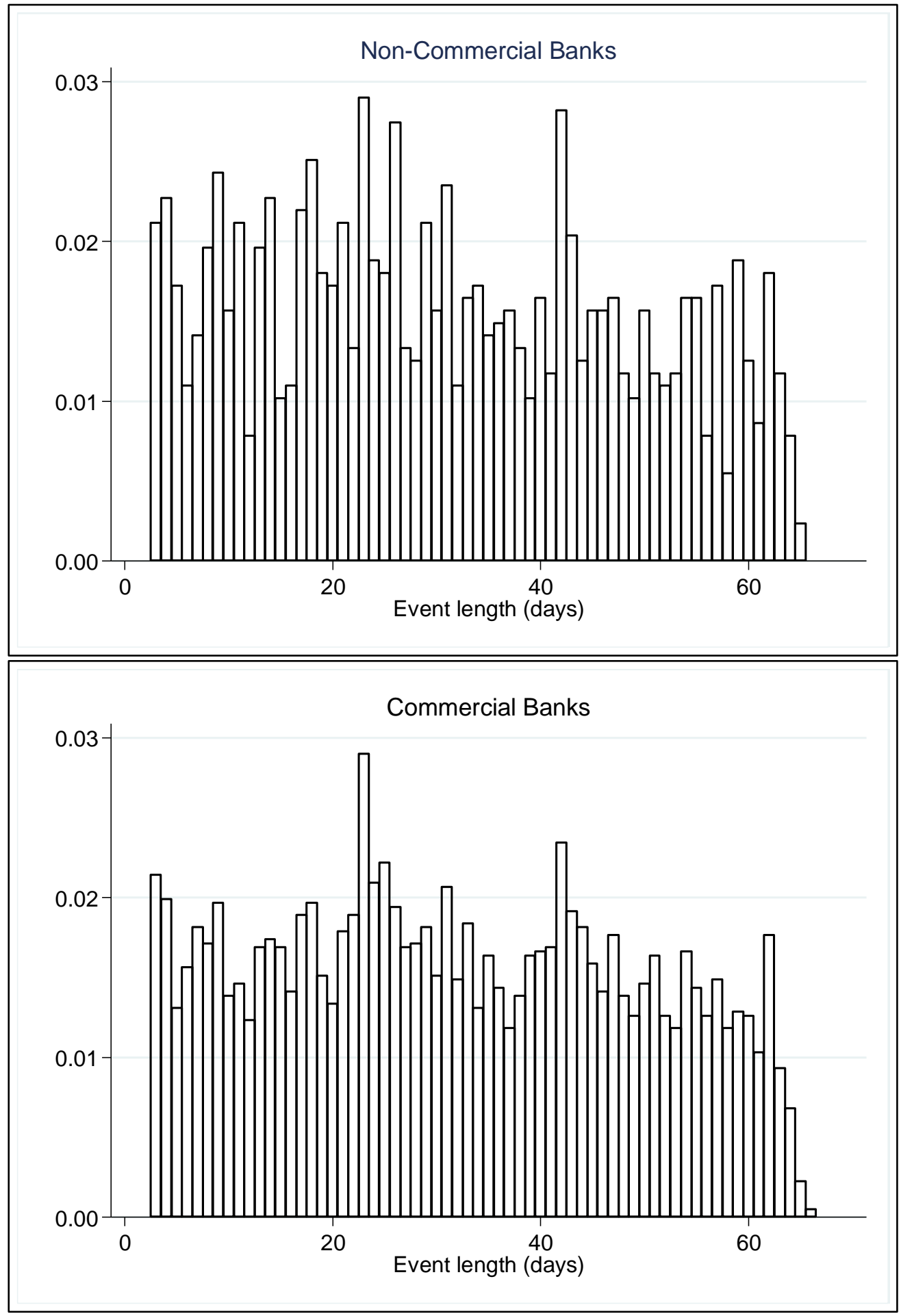

The graphs above present histogram of the number of days between the loan origination date and firms' earnings announcement date (a maximum of three months) for the commercial and non-commercial bank sample, when dual-holders have access to material non-public information that is not available to other shareholders. Facilities with fewer than 3 days or more than 93 days between the loan origination date and earnings announcement date are removed from the sample. 
Figure 3-Chapter 2: Timeline of events

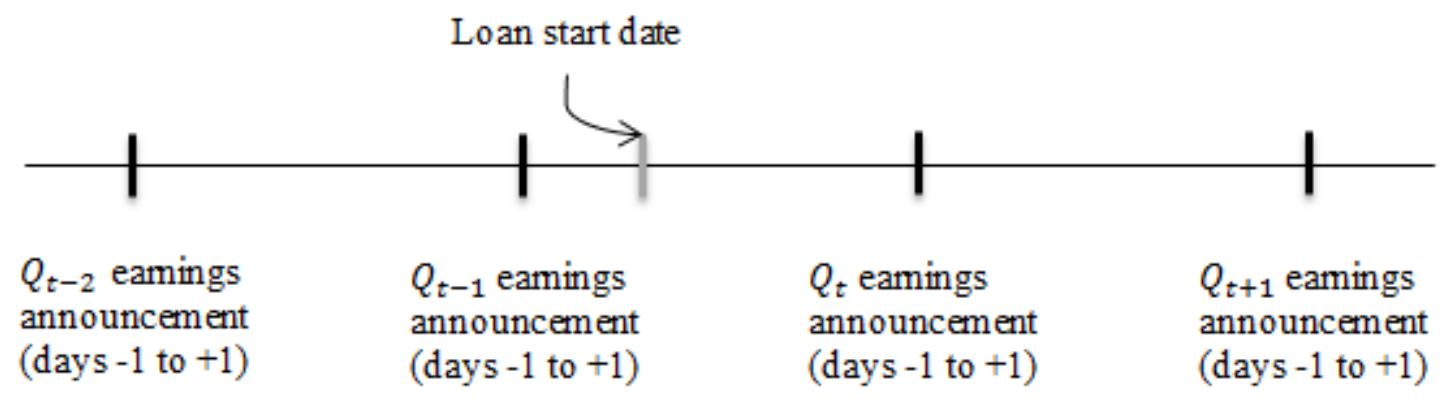

The figure above displays the timeline of events in comparing the level of a firm's information asymmetry before and after dual-holder participation. 
Table 1 - Composition of syndicated loans in DealScan

\begin{tabular}{|c|c|c|c|c|c|c|c|c|}
\hline & (1) & (2) & (3) & (4) & (5) & (6) & (7) & (8) \\
\hline Year & $\begin{array}{c}\text { Total } \\
\text { number of } \\
\text { lenders }\end{array}$ & $\begin{array}{l}\text { Total \# of } \\
\text { facilities }\end{array}$ & $\begin{array}{c}\text { Total \$ facilities } \\
\text { (millions) }\end{array}$ & $\begin{array}{c}\text { Non-bank } \\
\text { participation-\% } \\
\text { of \# facilities }\end{array}$ & $\begin{array}{c}\text { Non-bank } \\
\text { participation-\% } \\
\text { of } \$ \text { facilities }\end{array}$ & $\begin{array}{l}\text { Dual-holder } \\
\text { participation-\% } \\
\text { of \# facilities }\end{array}$ & $\begin{array}{l}\text { Dual-Holder } \\
\text { participation- } \% \\
\text { of } \$ \text { facilities }\end{array}$ & $\begin{array}{c}\text { Dual-holder } \\
\text { participation as } \\
\% \text { of \# of loans } \\
\text { with non-bank } \\
\text { participation }\end{array}$ \\
\hline $2006-2007$ & 934 & 685 & 443,102 & $63.80 \%$ & $76.97 \%$ & $24.67 \%$ & $38.28 \%$ & $38.67 \%$ \\
\hline $2007-2008$ & 931 & 962 & 557,724 & $54.05 \%$ & $70.47 \%$ & $23.49 \%$ & $46.03 \%$ & $43.46 \%$ \\
\hline 2008-2009 & 421 & 562 & 182,831 & $43.42 \%$ & $70.37 \%$ & $13.17 \%$ & $32.13 \%$ & $30.33 \%$ \\
\hline 2009-2010 & 532 & 648 & 231,458 & $48.61 \%$ & $69.42 \%$ & $15.12 \%$ & $33.19 \%$ & $31.11 \%$ \\
\hline 2010-2011 & 969 & 1144 & 536,890 & $49.91 \%$ & $65.53 \%$ & $21.42 \%$ & $37.08 \%$ & $42.91 \%$ \\
\hline 2011-2012 & 948 & 1218 & 692,958 & $47.70 \%$ & $63.29 \%$ & $19.87 \%$ & $34.68 \%$ & $41.65 \%$ \\
\hline 2012-2013 & 870 & 1065 & 651,657 & $49.77 \%$ & $59.57 \%$ & $21.50 \%$ & $34.85 \%$ & $43.21 \%$ \\
\hline 2013-2014 & 338 & 537 & 365,998 & $43.02 \%$ & $49.74 \%$ & $17.13 \%$ & $24.54 \%$ & $39.83 \%$ \\
\hline Average & 742 & 852 & 457,827 & $50.04 \%$ & $65.67 \%$ & $19.55 \%$ & $35.10 \%$ & $38.90 \%$ \\
\hline
\end{tabular}

This table displays historical participation of non-bank institutional investors in the syndicated loan market from 2006 to 2014 in the sample data. 
Table 2 - Sample selection

Panel A: DealScan- The number of borrowing firms and facilities at each stage of sample selection

\begin{tabular}{lcc}
\hline & Firms & Facilities \\
\hline Overall DealScan sample (from 2007) & 32,762 & 98,842 \\
Exclude if company name or syndication dates are missing & 31,031 & 93,737 \\
Exclude non-US syndicates & 12,114 & 35,179 \\
Exclude facilities that are not lines of credit or term-loans & 11,733 & 33,495 \\
Exclude facilities with missing all-drawn-in spread & 10,669 & 29,758 \\
Exclude facilities without LIBOR base rate & 10,560 & 29,436 \\
Exclude non-US lenders & 3,417 & 13,126 \\
Exclude borrowers without GVKEY & 3,182 & 11,698 \\
\hline
\end{tabular}

Panel B: Dual-holding funds

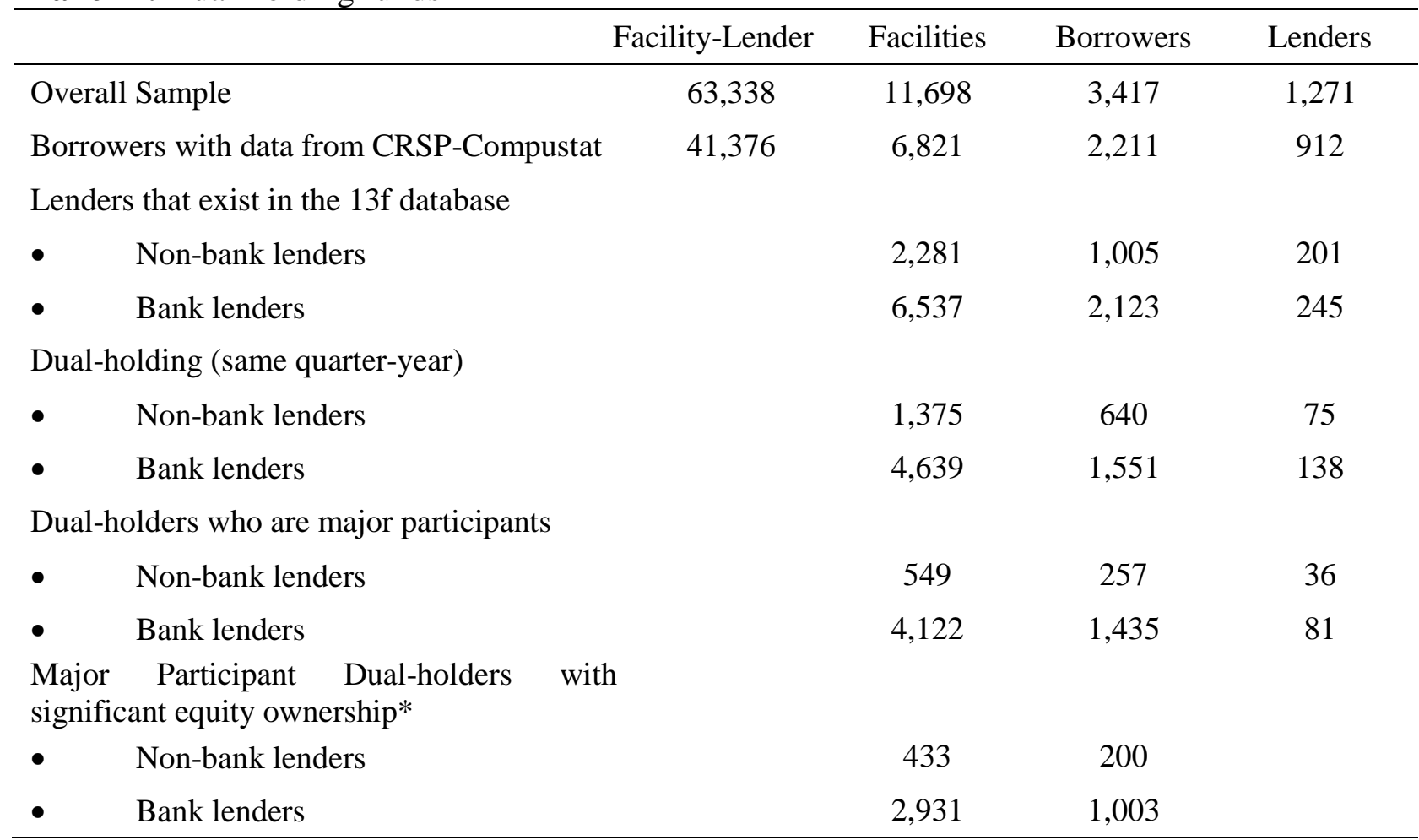

*Significant equity-holding is defined as holdings with a dollar value equal or above \$2M or $2 \%$ of the firm's total shares outstanding. 
Panel C: Unique non-bank facilities by type

\begin{tabular}{llcc}
\hline & & \# of Facilities & $\begin{array}{c}\text { \# of Dual-holder } \\
\text { facilities }\end{array}$ \\
\hline 1. Investment bank & 1,927 & 857 \\
2. Insurance company & 28 & 3 \\
3. Finance company & 1,939 & 630 \\
4. Mutual fund & 9 & 1 \\
5. Hedge/Vulture fund & 2 & 0 \\
6. Pension fund & 0 & 0 \\
7. Other & 415 & 51 \\
\hline
\end{tabular}

Panel D: Dual-holding facilities by investment horizon of the dual-holder

\# of Facilities

Non-bank dual-holders

- Dedicated 2

- Quasi-indexer $\quad 1,120$

- Transient 412

- Not classified 10

bank dual-holders

- Dedicated 93

- Quasi-indexer 4,399

- Transient 1,364

- Not classified 101 
Table 3 - Summary statistics

\begin{tabular}{|c|c|c|c|c|c|c|c|c|}
\hline \multirow[b]{2}{*}{ Variable } & \multicolumn{2}{|c|}{ Non-bank facilities } & \multicolumn{2}{|c|}{ Bank-only facilities } & \multicolumn{2}{|c|}{ Non-bank dual-holders } & \multicolumn{2}{|c|}{ Bank dual-holders } \\
\hline & $\mathrm{N}$ & Mean & $\mathrm{N}$ & Mean & $\mathrm{N}$ & Mean & $\mathrm{N}$ & Mean \\
\hline FRQ(DD) & 3299 & -0.0313 & 3284 & -0.0347 & 1324 & -0.0284 & 4506 & -0.0304 \\
\hline FRQ(STUB) & 2954 & -0.0182 & 3092 & -0.0229 & 1276 & -0.0168 & 4174 & -0.0189 \\
\hline $\mathrm{FRQ}(\mathrm{KO})$ & 2954 & -0.0396 & 3092 & -0.0422 & 1276 & -0.0379 & 4174 & -0.0385 \\
\hline Log(analysts) & 2485 & 2.2470 & 2576 & 2.0160 & 1235 & 2.3800 & 4028 & 2.2360 \\
\hline Disagree & 2429 & 0.1720 & 2499 & 0.1750 & 1213 & 0.1450 & 3969 & 0.1570 \\
\hline Log(facility amount) & 2955 & 5.8630 & 3092 & 5.0830 & 1277 & 6.2780 & 4174 & 5.7800 \\
\hline Maturity & 2955 & 3.9100 & 3092 & 3.7830 & 1277 & 3.8910 & 4174 & 3.8570 \\
\hline Secured flag & 2266 & 0.6420 & 2002 & 0.6950 & 982 & 0.5110 & 2836 & 0.5740 \\
\hline Revolver flag & 2955 & 0.6600 & 3092 & 0.6870 & 1277 & 0.6790 & 4174 & 0.6960 \\
\hline LBO flag & 2955 & 0.0085 & 3092 & 0.0048 & 1277 & 0.0055 & 4174 & 0.0031 \\
\hline Number of lenders & 2955 & 2.3620 & 3092 & 1.7050 & 1277 & 2.5870 & 4174 & 2.2260 \\
\hline $\log ($ asset $)$ & 2955 & 8.2010 & 3092 & 7.3030 & 1277 & 8.8680 & 4174 & 8.1410 \\
\hline Leverage & 2946 & 0.3000 & 3083 & 0.2500 & 1273 & 0.3000 & 4160 & 0.2710 \\
\hline Book-to-market ratio & 2808 & 1.0435 & 2903 & 1.0246 & 1203 & 1.0486 & 3927 & 0.9993 \\
\hline Inst. ownership & 2738 & 0.8360 & 2883 & 0.7840 & 1272 & 0.8330 & 4139 & 0.8420 \\
\hline Z-score & 2641 & 2.0410 & 2731 & 2.3390 & 1117 & 2.1100 & 3675 & 2.3600 \\
\hline Log(market value) & 2955 & 7.8000 & 3082 & 6.9870 & 1277 & 8.5050 & 4167 & 7.8550 \\
\hline$\Delta$ Sales-3yr & 2791 & 0.3810 & 2958 & 0.3330 & 1213 & 0.3910 & 4022 & 0.3430 \\
\hline Illiquidity $\left(* 10^{4}\right)$ & 2857 & 0.9630 & 3017 & 1.8500 & 1264 & 0.4260 & 4138 & 0.7650 \\
\hline
\end{tabular}

This table presents summary statistics of the sample. See the appendix for variable descriptions. 
Table 4 - Univariate analysis

Panel A: Financial reporting quality and investors' loan participation

\begin{tabular}{|c|c|c|c|c|c|c|}
\hline \multirow[b]{2}{*}{ Variable } & \multicolumn{3}{|c|}{ Facilities with non-bank participation } & \multicolumn{3}{|c|}{ Facilities with bank-only participation } \\
\hline & Low FRQ & High FRQ & Low-High & Low FRQ & High FRQ & Low-High \\
\hline Number of facilities & 1133 & 1097 & 36 & 1040 & 1105 & -65 \\
\hline FRQ (DD) & -0.056 & -0.010 & $-0.033 * * *$ & -0.064 & -0.011 & $-0.052 * * *$ \\
\hline FRQ (STUB) & -0.022 & -0.012 & $-0.017 * * *$ & -0.032 & -0.014 & $-0.018 * * *$ \\
\hline FRQ (KO) & -0.060 & -0.024 & $-0.042 * * *$ & -0.062 & -0.027 & $-0.034 * * *$ \\
\hline Log(analysts) & 2.300 & 2.157 & $0.143^{* * *}$ & 1.996 & 1.936 & $0.059 *$ \\
\hline Disagree & 0.101 & 0.107 & -0.005 & 0.131 & 0.118 & 0.012 \\
\hline All-in-drawn & 219 & 221 & -2.498 & 212 & 209 & 2.176 \\
\hline $\log ($ facility amount $)$ & 5.916 & 6.032 & $-0.116^{* *}$ & 4.994 & 5.304 & $-0.310 * * *$ \\
\hline $\log$ (maturity) & 3.925 & 3.887 & $0.037 * *$ & 3.758 & 3.843 & $-0.084 * * *$ \\
\hline $\log ($ number of lenders) & 2.351 & 2.446 & $-0.095 * * *$ & 1.661 & 1.807 & $-0.146 * * *$ \\
\hline $\log ($ asset $)$ & 8.099 & 8.519 & $-0.420 * * *$ & 6.917 & 7.628 & $-0.711 * * *$ \\
\hline Leverage & 0.255 & 0.327 & $-0.071 * * *$ & 0.191 & 0.277 & $-0.086 * * *$ \\
\hline Book-to-market ratio & 0.919 & 1.228 & $-0.308 * * *$ & 0.938 & 1.107 & $-0.168 * * *$ \\
\hline Inst. ownership & 0.786 & 0.736 & $0.049 * * *$ & 0.719 & 0.696 & $0.022 * *$ \\
\hline Z-score & 2.535 & 1.696 & $0.839 * * *$ & 2.812 & 2.055 & $0.756^{* * *}$ \\
\hline $\log ($ market value $)$ & 7.985 & 7.908 & 0.076 & 6.887 & 7.137 & $-0.249 * * *$ \\
\hline$\Delta$ Sales-3yr & 0.489 & 0.269 & $0.219 * * *$ & 0.451 & 0.250 & $0.201 * * *$ \\
\hline Illiquidity $\left(* 10^{4}\right)$ & 0.631 & 0.718 & -0.087 & 1.500 & 1.320 & $0.180 * *$ \\
\hline
\end{tabular}

This table provides univariate analyses of variables by sorting facilities first into deciles based on borrower market value and then into terciles by the accruals quality. T-statistics in parentheses. *, **, *** indicate significance at $0.10,0.05$, and 0.01 levels using two-tailed tests. See the appendix for variable descriptions. 
Panel B: Financial reporting quality and investors' dual-holding

\begin{tabular}{|c|c|c|c|c|c|c|}
\hline \multirow[b]{2}{*}{ Variable } & \multicolumn{3}{|c|}{ Non-bank dual-holder } & \multicolumn{3}{|c|}{ Bank Dual-holder } \\
\hline & Low & High & Low-High & Low & High & Low-High \\
\hline Number of facilities & 462 & 440 & 22 & 1040 & 1148 & -108 \\
\hline FRQ (DD) & -0.052 & -0.009 & $-0.042 * * *$ & -0.057 & -0.011 & $-0.046^{* * *}$ \\
\hline FRQ (STUB) & -0.019 & -0.011 & $-0.008 * * *$ & -0.027 & -0.013 & $-0.013 * * *$ \\
\hline FRQ (KO) & -0.055 & -0.021 & $-0.034 * * *$ & -0.059 & -0.025 & $-0.033 * * *$ \\
\hline Log(analysts) & 2.455 & 2.263 & $0.192 * * *$ & 2.149 & 2.047 & $0.102 * * *$ \\
\hline Disagree & 0.094 & 0.110 & $-0.015^{*}$ & 0.117 & 0.112 & 0.006 \\
\hline All-in-drawn & 192 & 195 & 3 & 190 & 198 & $8^{*}$ \\
\hline $\log ($ facility amount $)$ & 6.313 & 6.386 & -0.073 & 5.523 & 5.660 & $-0.136 * * *$ \\
\hline $\log$ (maturity) & 3.931 & 3.877 & $0.053 * *$ & 3.831 & 3.880 & $-0.048 * *$ \\
\hline $\log$ (number of lenders) & 2.543 & 2.605 & $-0.061 * *$ & 2.060 & 2.096 & -0.035 \\
\hline $\log ($ asset $)$ & 8.682 & 9.113 & $-0.431 * * *$ & 7.539 & 8.015 & $-0.476^{* * *}$ \\
\hline Leverage & 0.276 & 0.313 & $-0.036^{* * *}$ & 0.207 & 0.281 & $-0.074 * * *$ \\
\hline Book-to-market ratio & 0.897 & 1.326 & $-0.428 * * *$ & 0.893 & 1.084 & $-0.190 * * *$ \\
\hline Inst. ownership & 0.808 & 0.745 & $0.063 * * *$ & 0.786 & 0.752 & $0.033 * * *$ \\
\hline Z-score & 2.525 & 1.717 & $0.808^{* * *}$ & 3.044 & 2.040 & $1.003^{* * *}$ \\
\hline Log(market value) & 8.614 & 8.521 & 0.092 & 7.523 & 7.572 & -0.049 \\
\hline$\Delta$ Sales-3yr & 0.521 & 0.261 & $0.260 * * *$ & 0.420 & 0.252 & $0.167 * * *$ \\
\hline $\operatorname{Illiquidity}\left(* 10^{4}\right)$ & 0.225 & 0.317 & $-0.092 * *$ & 0.756 & 0.804 & 0.048 \\
\hline
\end{tabular}

This table provides univariate analyses of variables by sorting facilities first into deciles based on borrower market value and then into terciles by the accruals quality. T-statistics in parentheses. ${ }^{*}, * *, * * *$ indicate significance at $0.10,0.05$, and 0.01 levels using two-tailed tests. See the appendix for variable descriptions. 
Table 5-Financial reporting quality and dual-holding

Panel A: Determinants of non-bank versus bank investors' participation in a facility

(1) (2)

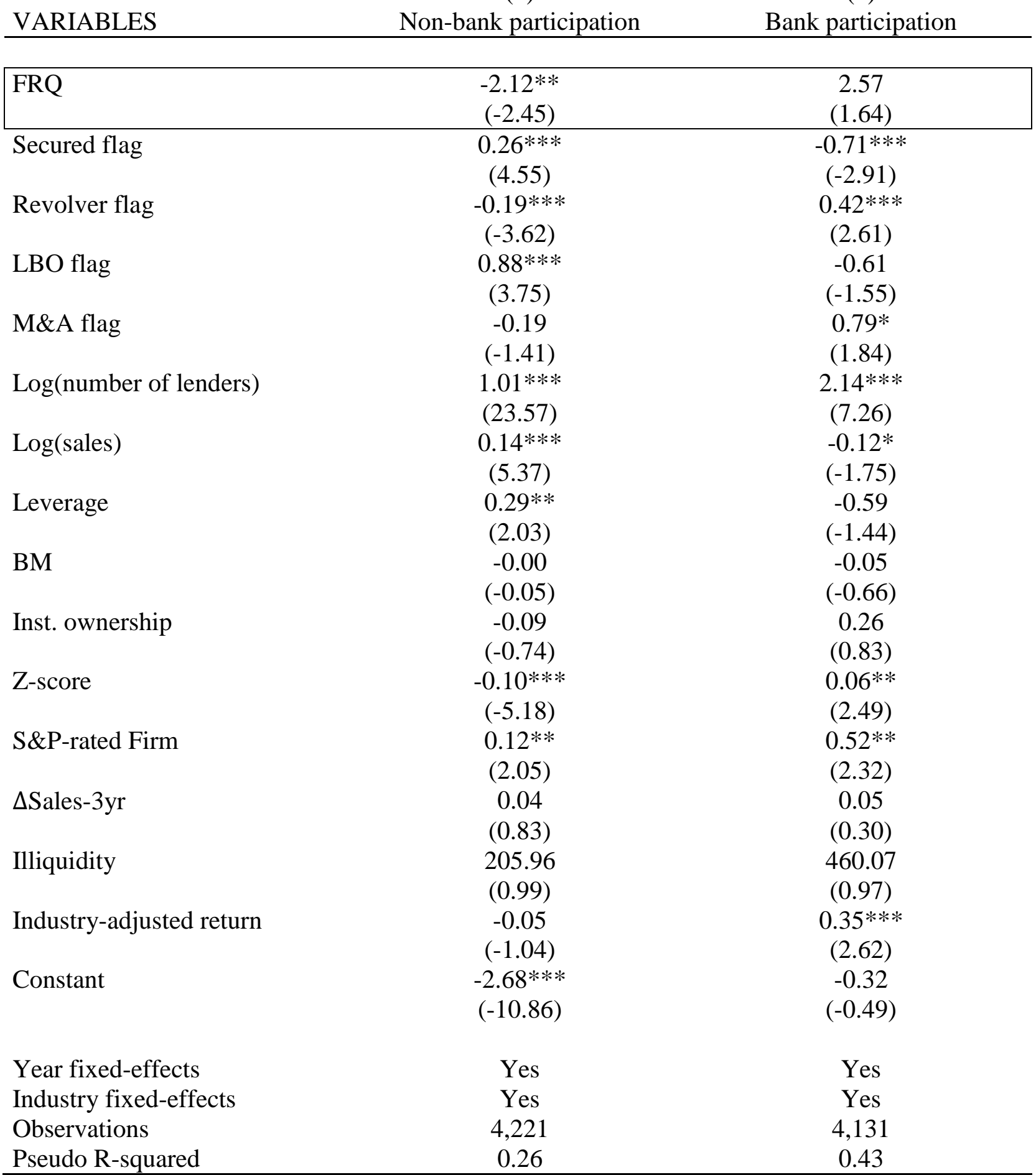

This table presents results of the probit model of investors' participation in a loan facility. Robust zstatistics in parentheses. $*, * *, * * *$ indicate significance at $0.10,0.05$, and 0.01 levels using two-tailed tests. See the appendix for variable descriptions 
Panel B: Determinants of non-bank versus bank investors' dual-holding

\begin{tabular}{|c|c|c|c|c|}
\hline \multirow[b]{3}{*}{ VARIABLES } & \multirow{2}{*}{\multicolumn{2}{|c|}{ Sample $=$ All }} & \multirow{2}{*}{\multicolumn{2}{|c|}{$\begin{array}{cc}(3) & (4) \\
\text { Sample=Institutional participation }\end{array}$}} \\
\hline & & & & \\
\hline & $\begin{array}{l}\text { Non-bank dual- } \\
\text { holding }\end{array}$ & Bank dual-holding & $\begin{array}{l}\text { Non-bank dual- } \\
\text { holding }\end{array}$ & Bank dual-holding \\
\hline FRQ & $\begin{array}{c}-2.73 * * * \\
(-2.70)\end{array}$ & $\begin{array}{l}-0.10 \\
(-0.12)\end{array}$ & $\begin{array}{l}-2.25^{*} \\
(-1.88)\end{array}$ & $\begin{array}{c}-0.85 \\
(-0.60)\end{array}$ \\
\hline Secured $(0 / 1)$ & $\begin{array}{c}-0.02 \\
(-0.28)\end{array}$ & $\begin{array}{c}-0.53 * * * \\
(-6.70)\end{array}$ & $\begin{array}{c}-0.21 * * * \\
(-2.93)\end{array}$ & $\begin{array}{c}-0.83 * * * \\
(-5.74)\end{array}$ \\
\hline Revolver $(0 / 1)$ & $\begin{array}{l}-0.11 * * \\
(-2.03)\end{array}$ & $\begin{array}{c}0.23 * * * \\
(3.57)\end{array}$ & $\begin{array}{l}-0.07 \\
(-1.05)\end{array}$ & $\begin{array}{c}0.31 * * * \\
(3.46)\end{array}$ \\
\hline $\operatorname{LBO}(0 / 1)$ & $\begin{array}{c}-0.66 * * * \\
(-2.64)\end{array}$ & $\begin{array}{c}-2.63 * * * \\
(-7.96)\end{array}$ & $\begin{array}{c}-1.06 * * * \\
(-4.65)\end{array}$ & $\begin{array}{c}-2.73 * * * \\
(-6.26)\end{array}$ \\
\hline$M \& A(0 / 1)$ & $\begin{array}{l}-0.17 \\
(-1.15)\end{array}$ & $\begin{array}{l}-0.25 \\
(-1.46)\end{array}$ & $\begin{array}{l}-0.15 \\
(-0.79)\end{array}$ & $\begin{array}{l}-0.26 \\
(-1.08)\end{array}$ \\
\hline $\log ($ number of lenders) & $\begin{array}{r}0.82 * * * \\
(17.61)\end{array}$ & $\begin{array}{l}1.12 * * * \\
(20.65)\end{array}$ & $\begin{array}{c}0.38 * * * \\
(6.69)\end{array}$ & $\begin{array}{l}1.46^{* * * *} \\
(15.04)\end{array}$ \\
\hline $\log$ (sales) & $\begin{array}{c}0.26^{* * * *} \\
(9.18)\end{array}$ & $\begin{array}{c}0.18 * * * \\
(5.28)\end{array}$ & $\begin{array}{c}0.28 * * * \\
(8.47)\end{array}$ & $\begin{array}{c}0.19 * * * \\
(3.95)\end{array}$ \\
\hline Leverage & $\begin{array}{l}0.90 * * * \\
(5.08)\end{array}$ & $\begin{array}{l}-0.29 * \\
(-1.84)\end{array}$ & $\begin{array}{c}0.96^{* * * *} \\
(4.99)\end{array}$ & $\begin{array}{l}-0.14 \\
(-0.60)\end{array}$ \\
\hline BM & $\begin{array}{r}-0.16^{* *} \\
(-2.23)\end{array}$ & $\begin{array}{l}-0.15^{* *} \\
(-2.37)\end{array}$ & $\begin{array}{r}-0.17 * * \\
(-2.29)\end{array}$ & $\begin{array}{l}-0.09 \\
(-0.78)\end{array}$ \\
\hline Inst. ownership & $\begin{array}{c}0.02 \\
(0.18)\end{array}$ & $\begin{array}{c}0.75^{* * *} \\
(4.77)\end{array}$ & $\begin{array}{c}0.09 \\
(0.50)\end{array}$ & $\begin{array}{c}1.13 * * * \\
(4.46)\end{array}$ \\
\hline Z-score & $\begin{array}{c}-0.07 * * \\
(-2.23)\end{array}$ & $\begin{array}{c}-0.05^{* *} \\
(-2.34)\end{array}$ & $\begin{array}{c}-0.04 \\
(-1.46)\end{array}$ & $\begin{array}{c}-0.08^{* * *} \\
(-2.12)\end{array}$ \\
\hline S\&P-rated firm & $\begin{array}{c}0.33 * * * \\
(4.62)\end{array}$ & $\begin{array}{c}0.00 \\
(0.02)\end{array}$ & $\begin{array}{c}0.31^{* * *} \\
(3.84)\end{array}$ & $\begin{array}{c}0.05 \\
(0.47)\end{array}$ \\
\hline$\Delta$ Sales-3yr & $\begin{array}{c}0.16 * * * \\
(3.16)\end{array}$ & $\begin{array}{c}-0.04 \\
(-0.69)\end{array}$ & $\begin{array}{c}0.20 * * * \\
(3.31)\end{array}$ & $\begin{array}{c}0.01 \\
(0.11)\end{array}$ \\
\hline Illiquidity $\left(* 10^{4}\right)$ & $\begin{array}{l}-0.05^{*} \\
(-1.92)\end{array}$ & $\begin{array}{c}-0.10^{* * *} \\
(-4.03)\end{array}$ & $\begin{array}{c}-0.09 * * * \\
(-2.78)\end{array}$ & $\begin{array}{c}-0.11^{* * *} \\
(-2.78)\end{array}$ \\
\hline Industry-adjusted return & $\begin{array}{c}-0.14 * * \\
(-2.42)\end{array}$ & $\begin{array}{c}-0.01 \\
(-0.25)\end{array}$ & $\begin{array}{c}-0.16^{* *} \\
(-2.20)\end{array}$ & $\begin{array}{c}-0.04 \\
(-0.59)\end{array}$ \\
\hline Constant & $\begin{array}{c}-4.54 * * * \\
(-16.25)\end{array}$ & $\begin{array}{c}-2.40 * * * \\
(-7.85)\end{array}$ & $\begin{array}{c}-3.23 * * * \\
(-9.35)\end{array}$ & $\begin{array}{c}-3.57 * * * \\
(-7.23)\end{array}$ \\
\hline Year fixed-effects & Yes & Yes & Yes & Yes \\
\hline Industry fixed-effects & Yes & Yes & Yes & Yes \\
\hline Observations & 4,221 & 4,221 & 2,474 & 2,474 \\
\hline Pseudo R-squared & 0.32 & 0.45 & 0.23 & 0.53 \\
\hline
\end{tabular}

This table presents the results of the probit model of investors' dual-holding in a facility. Robust $\mathrm{z}$ statistics in parentheses. $*, * *, * * *$ indicate significance at $0.10,0.05$, and 0.01 levels using two-tailed tests. See the appendix for variable descriptions 
Table 6 - Portfolios returns of loan participants

Panel A: Unadjusted abnormal excess returns

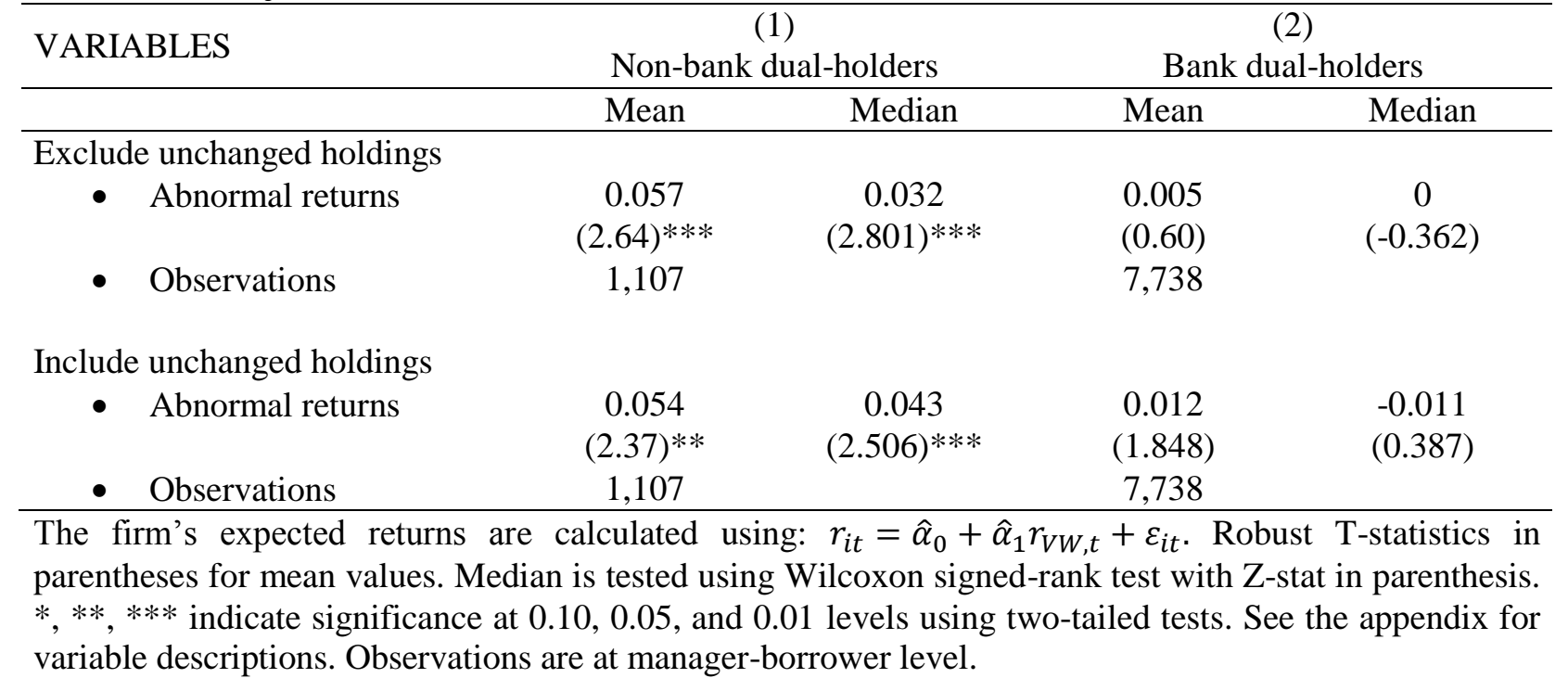

Panel B: Risk-adjusted abnormal excess returns using the Fama-French 3-factor model

\begin{tabular}{|c|c|c|c|c|}
\hline \multirow[t]{2}{*}{ VARIABLES } & \multicolumn{2}{|c|}{$\begin{array}{c}\text { (1) } \\
\text { Non-bank dual-holders }\end{array}$} & \multicolumn{2}{|c|}{$\begin{array}{c}\text { (2) } \\
\text { Bank dual-holders } \\
\end{array}$} \\
\hline & Mean & Median & Mean & Median \\
\hline Exclude unchanged holdings & & & & \\
\hline - Abnormal returns & $\begin{array}{c}0.063 \\
(2.74)^{* * * *}\end{array}$ & $\begin{array}{c}0.052 \\
(2.819)^{* * *}\end{array}$ & $\begin{array}{c}0.017 \\
(1.98)^{* *}\end{array}$ & $\begin{array}{c}0 \\
(0.703)\end{array}$ \\
\hline - Observations & 1,107 & & 7,738 & \\
\hline Include unchanged holdings & & & & \\
\hline $\begin{array}{l}\text { - Abnormal returns } \\
\text { - Observations }\end{array}$ & $\begin{array}{c}0.061 \\
(2.53)^{* *} \\
1.107\end{array}$ & $\begin{array}{c}0.072 \\
(2.649)^{* * *}\end{array}$ & $\begin{array}{c}0.020 \\
(2.32)^{* *} \\
7.738\end{array}$ & $\begin{array}{c}0 \\
(1.026)\end{array}$ \\
\hline
\end{tabular}

The firm's expected returns are calculated using the Fama-French three-factor model: $r_{i t}=r_{f}+$ $\hat{\alpha}_{1}\left(r_{m t}-r_{f}\right)+\hat{\alpha}_{2} S M B_{t}+\hat{\alpha}_{3} H M L_{t}+\varepsilon_{i t}$. Robust T-statistics in parentheses for mean values. Median is tested using Wilcoxon signed-rank test with Z-stat in parenthesis. *,**,*** indicate significance at 0.10 , 0.05 , and 0.01 levels using two-tailed tests. Observations are at fund manager-borrower level. See the appendix for variable descriptions. 
Panel C: Risk-adjusted abnormal excess returns using the Fama-French 3-factor model by Trade-direction

\begin{tabular}{lcc}
\hline & \multicolumn{2}{c}{ Non-bank dual-holders } \\
VARIABLES & Mean & Median \\
\cline { 2 - 3 } Exclude unchanged holdings (Buy) & 0.067 & 0.059 \\
- Abnormal returns & $(1.94)^{*}$ & $(1.74)^{*}$ \\
- Observations & 520 & 0.051 \\
Include unchanged holdings (Buy) & 0.061 & $(1.55)$ \\
- Abnormal returns & $(1.76)^{*}$ & \\
- Observations & 543 & \\
Exclude unchanged holdings (Sell) & & 0.082 \\
- Abnormal returns & & $(2.46)^{* *}$ \\
- Observations & 0.062 & \\
Include unchanged holdings (Sell) & $(1.93)^{*}$ & 0.082 \\
$\bullet \quad$ Abnormal returns & 564 & $(2.47)^{* *}$ \\
\hline
\end{tabular}

The firm's expected returns are calculated using the Fama-French three-factor model: $r_{i t}=r_{f}+$ $\hat{\alpha}_{1}\left(r_{m t}-r_{f}\right)+\hat{\alpha}_{2} S M B_{t}+\hat{\alpha}_{3} H M L_{t}+\varepsilon_{i t}$. Robust T-statistics in parentheses for mean values. Median is tested using Wilcoxon signed-rank test with Z-stat in parenthesis. *, **, *** indicate significance at 0.10 , 0.05 , and 0.01 levels using two-tailed tests. Observations are at fund manager-borrower level. See the appendix for variable descriptions. 
Table 7 - Portfolio returns of dual-holders by accounting quality

Panel A: Results using total accruals

\begin{tabular}{lccc}
\hline VARIABLES & \multicolumn{2}{c}{ FRQ } & \\
\cline { 2 - 3 } & Low & High & Low-High \\
\hline Exclude unchanged holdings & & & \\
• Abnormal returns & 0.024 & 0.032 & -0.008 \\
& $(0.57)$ & $(0.88)$ & $(-0.151)$ \\
- Observations & 361 & 358 & \\
Include unchanged holdings & & & \\
- Abnormal returns & 0.024 & 0.029 & -0.005 \\
- Observations & $(0.55)$ & $(0.77)$ & $(-0.092)$ \\
\hline
\end{tabular}

Panel B: Results using innate accruals

\begin{tabular}{lccc}
\hline VARIABLES & \multicolumn{2}{c}{ Innate Accruals Quality } & \multirow{2}{*}{ Low-High } \\
\cline { 2 - 3 } Exclude unchanged holdings & Low & High & \\
- Abnormal returns & 0.007 & 0.133 & -0.126 \\
- Observations & $(0.17)$ & $(3.44)^{* * *}$ & $(-2.262)^{* * *}$ \\
Include unchanged holdings & 370 & 369 & \\
- Abnormal returns & & & \\
- Observations & 0 & 0.131 & -0.131 \\
& $(0.00)$ & $(3.26)^{* * *}$ & $(-2.263)^{* * *}$ \\
\hline
\end{tabular}

Panel C: Results using discretionary accruals

\begin{tabular}{lccc}
\hline VARIABLES & \multicolumn{2}{c}{ Discretionary } & \multicolumn{2}{c}{ Accruals Quality } & Low-High \\
\cline { 2 - 3 } & Low & High & \\
Exclude unchanged holdings & & & 0.035 \\
• Abnormal returns & 0.094 & $(1.34)$ & $(0.652)$ \\
- Observations & $(2.28)^{* *}$ & 369 & \\
Include unchanged holdings & 372 & & \\
- Abnormal returns & & & \\
& & 0.038 & 0.058 \\
- Observations & $(2.28)^{* *}$ & $(0.90)$ & $(0.961)$ \\
\hline
\end{tabular}

The firm's expected returns are calculated using the Fama-French three-factor model: $r_{i t}=r_{f}+$ $\widehat{\alpha}_{1}\left(r_{m t}-r_{f}\right)+\widehat{\alpha}_{2} S_{M B}+\widehat{\alpha}_{3} H_{M L}+\varepsilon_{i t}$. High and low refer to the top and bottom terciles of each variable in the overall sample. Accruals are multiplied by -1 such that a lower value refers to lower quality accruals. Innate and discretionary accruals are calculated according to Francis et al. (2005). Mean of the values are used in tables, however inferences remain unchanged using median values. *, **, **** indicate significance at $0.10,0.05$, and 0.01 levels using two-tailed tests. Observations are at fund manager-borrower level. See the appendix for variable descriptions. 
Table 8 - Loan participants equity vs. loan position size

Panel A: Dual-holders' returns by dual-holder's equity to loan size

\begin{tabular}{lccccc}
\hline VARIABLES & \multicolumn{5}{c}{ Lenders' Equity/Loan (dollar value) Ownership Quintiles } \\
\cline { 2 - 6 } Abnormal Returns & Low & 2 & 3 & 4 & High \\
$(0.4 \%-4.6 \%)$ & $(4.7 \%-17.1 \%)$ & $(17.2 \%-42.7 \%)$ & $(42.8 \%-100.2 \%)$ & $(100.3 \%-500.7 \%)$ \\
\hline Include unchanged holdings & & & 0.143 & 0.048 & 0.063 \\
- Mean & 0.045 & 0.017 & 0.113 & 213 & 0.047 \\
- Median & 0 & 0.025 & 213 & 0.048 & 212 \\
- Observations & 213 & 213 & & 0.075 & 0.063 \\
Exclude unchanged holdings & & & 0.134 & 0.047 \\
- Mean & 0.048 & 0.012 & 0.113 & 213 \\
- Median & 0.044 & 0.027 & 213 & & 212 \\
- Observations & 213 & 213 & &
\end{tabular}

Panel B: Dual-holders' positive returns by dual-holder's equity to loan size and direction of the trade

\begin{tabular}{|c|c|c|c|c|c|}
\hline \multirow[t]{2}{*}{ VARIABLES } & \multicolumn{5}{|c|}{ Lenders' Equity/Loan (dollar value) Ownership Quintiles } \\
\hline & Low & 2 & 3 & 4 & High \\
\hline Abnormal Returns & $(0.4 \%-4.6 \%)$ & $(4.7 \%-17.1 \%)$ & $(17.2 \%-42.7 \%)$ & $(42.8 \%-100.2 \%)$ & $(100.3 \%-500.7 \%)$ \\
\hline \multicolumn{6}{|l|}{ Returns from "Buy" } \\
\hline - Mean & 0.643 & 0.624 & 0.527 & 0.535 & 0.493 \\
\hline - Median & 0.393 & 0.411 & 0.321 & 0.328 & 0.287 \\
\hline - Observations & 51 & 47 & 63 & 62 & 72 \\
\hline \multicolumn{6}{|l|}{ Returns from "Sell" } \\
\hline - Mean & 0.581 & 0.653 & 0.579 & 0.524 & 0.551 \\
\hline - Median & 0.476 & 0.416 & 0.469 & 0.395 & 0.410 \\
\hline - Observations & 70 & 64 & 64 & 56 & 45 \\
\hline
\end{tabular}


Panel C: Dual-holders' negative returns by dual-holder's equity to loan size and direction of the trade

\begin{tabular}{|c|c|c|c|c|c|}
\hline \multirow[t]{2}{*}{ VARIABLES } & \multicolumn{5}{|c|}{ Lenders' Equity/Loan (dollar value) Ownership Quintiles } \\
\hline & Low & 2 & 3 & 4 & High \\
\hline Abnormal Returns & $(0.4 \%-4.6 \%)$ & $(4.7 \%-17.1 \%)$ & $(17.2 \%-42.7 \%)$ & $(42.8 \%-100.2 \%)$ & $(100.3 \%-500.7 \%)$ \\
\hline \multicolumn{6}{|l|}{ Returns from "Buy" } \\
\hline - Mean & -0.737 & -0.732 & -0.445 & -0.577 & -0.409 \\
\hline - Median & -0.639 & -0.598 & -0.294 & -0.419 & -0.377 \\
\hline - Observations & 42 & 49 & 38 & 46 & 50 \\
\hline \multicolumn{6}{|l|}{ Returns from "Sell", } \\
\hline - Mean & -0.659 & -0.595 & -0.476 & -0.521 & -0.585 \\
\hline - Median & -0.481 & -0.416 & -0.354 & -0.273 & -0.400 \\
\hline - Observations & 50 & 53 & 48 & 49 & 45 \\
\hline
\end{tabular}

A lender's equity value is calculated as the total market value of shares held during the year-quarter of the facility start date. A lender's loan value is calculated by multiplying the percentage of their ownership in the loan by the total facility amount. The firm's expected returns are calculated using the Fama-French three-factor model: $r_{i t}=r_{f}+\hat{\alpha}_{1}\left(r_{m t}-r_{f}\right)+\hat{\alpha}_{2} S M B_{t}+\hat{\alpha}_{3} H M L_{t}+\varepsilon_{i t}$. Results shown use calculated returns by including unchanged holdings. Inferences remain if using returns that exclude unchanged positions. *, **, *** indicate significance at $0.10,0.05$, and 0.01 levels using two-tailed tests. See the appendix for variable descriptions. 
Table 9 - Dual-holders and loan characteristics

Panel A: The effect of dual-holder participation on loan covenants

\begin{tabular}{|c|c|c|c|c|}
\hline \multirow{3}{*}{ VARIABLES } & \multirow{2}{*}{\multicolumn{2}{|c|}{ Sample $=$ All }} & \multirow{2}{*}{\multicolumn{2}{|c|}{$\begin{array}{c}\text { (3) } \\
\text { Sample= Institutional participation }\end{array}$}} \\
\hline & & & & \\
\hline & Log(Cap-Cov ratio) & Log(Perf-Cov ratio) & \multicolumn{2}{|c|}{ Log(Cap-Cov ratio) $\log ($ Perf-Cov ratio $)$} \\
\hline \multirow[t]{2}{*}{ Dual-holder } & 0.02 & $-0.02 * *$ & 0.01 & -0.02 \\
\hline & $(1.23)$ & $(-2.03)$ & $(0.42)$ & $(-1.10)$ \\
\hline \multirow[t]{2}{*}{ FRQ } & $0.24 *$ & $-0.20 *$ & 0.09 & -0.07 \\
\hline & $(1.79)$ & $(-1.72)$ & $(0.34)$ & $(-0.28)$ \\
\hline \multirow[t]{2}{*}{ FRQ $\times$ Dual-holder } & 0.30 & $-0.42 * *$ & 0.34 & -0.45 \\
\hline & $(1.29)$ & $(-2.06)$ & $(1.06)$ & $(-1.59)$ \\
\hline \multirow[t]{2}{*}{$\log ($ loan amount $)$} & $0.01 *$ & $-0.01 *$ & 0.01 & $-0.01 *$ \\
\hline & $(1.74)$ & $(-1.89)$ & $(1.61)$ & $(-1.79)$ \\
\hline \multirow{2}{*}{$\log ($ loan maturity) } & $-0.05 * * *$ & $0.05^{* * *}$ & $-0.04 * *$ & $0.04 * *$ \\
\hline & $(-5.01)$ & $(4.80)$ & $(-2.44)$ & (2.39) \\
\hline \multirow[t]{2}{*}{ Lead-lender reputation } & $-0.02 * * *$ & $0.02 * * *$ & $-0.02 * *$ & $0.02 *$ \\
\hline & $(-2.99)$ & $(2.60)$ & $(-2.23)$ & $(1.95)$ \\
\hline \multirow[t]{2}{*}{ Lead-lender relation } & 0.00 & 0.00 & 0.01 & -0.00 \\
\hline & $(0.04)$ & $(0.74)$ & $(0.66)$ & $(-0.11)$ \\
\hline \multirow{2}{*}{ Secured $(0 / 1)$} & $-0.09 * * *$ & $0.09 * * *$ & $-0.10 * * *$ & $0.10 * * *$ \\
\hline & $(-10.32)$ & $(10.64)$ & $(-8.40)$ & $(8.84)$ \\
\hline \multirow[t]{2}{*}{ Revolver $(0 / 1)$} & $0.03 * * *$ & $-0.02 * * *$ & $0.02^{* * *}$ & $-0.02 * *$ \\
\hline & $(4.66)$ & $(-4.19)$ & (2.66) & $(-2.21)$ \\
\hline \multirow{2}{*}{$\operatorname{LBO}(0 / 1)$} & $0.09 *$ & $-0.06 *$ & $0.11 * *$ & $-0.08 * *$ \\
\hline & $(1.89)$ & $(-1.76)$ & $(2.26)$ & $(-2.18)$ \\
\hline \multirow[t]{2}{*}{$\mathrm{M} \& \mathrm{~A}(0 / 1)$} & -0.00 & 0.00 & 0.04 & -0.03 \\
\hline & $(-0.19)$ & $(0.11)$ & $(1.29)$ & $(-1.30)$ \\
\hline \multirow[t]{2}{*}{$\log ($ number of lenders) } & $-0.02 * * *$ & $0.02 * * *$ & $-0.02 * *$ & $0.02 * *$ \\
\hline & $(-3.39)$ & $(3.29)$ & $(-2.32)$ & $(2.31)$ \\
\hline \multirow[t]{2}{*}{$\log ($ Sales $)$} & $0.01 * *$ & $-0.01 * * *$ & $0.01 *$ & $-0.01 * *$ \\
\hline & $(2.36)$ & $(-3.27)$ & $(1.80)$ & $(-2.34)$ \\
\hline \multirow[t]{2}{*}{ Leverage } & $-0.07 * * *$ & $0.07^{* * * *}$ & -0.02 & 0.02 \\
\hline & $(-4.63)$ & $(4.73)$ & $(-1.13)$ & $(0.99)$ \\
\hline \multirow[t]{2}{*}{$\mathrm{BM}$} & -0.00 & 0.01 & -0.01 & 0.01 \\
\hline & $(-0.54)$ & $(1.14)$ & $(-0.94)$ & $(1.30)$ \\
\hline \multirow[t]{2}{*}{ Inst. ownership } & -0.03 & $0.03 *$ & $-0.04 * *$ & $0.04 *$ \\
\hline & $(-1.61)$ & $(1.65)$ & $(-2.00)$ & $(1.95)$ \\
\hline Z-score & 0.00 & 0.00 & 0.00 & 0.00 \\
\hline & $(0.09)$ & $(0.61)$ & $(0.00)$ & $(0.28)$ \\
\hline$S \& P$ rated firm $(0 / 1)$ & 0.01 & $-0.01 *$ & -0.00 & -0.01 \\
\hline & $(0.76)$ & $(-1.94)$ & $(-0.10)$ & $(-0.86)$ \\
\hline$\Delta$ Sales-3yr & -0.00 & 0.00 & -0.00 & 0.00 \\
\hline & $(-0.38)$ & $(0.32)$ & $(-0.17)$ & $(0.18)$ \\
\hline Illiquidity $\left(* 10^{4}\right)$ & $83.07 * * *$ & $-85.55^{* * *}$ & 15.03 & -32.71 \\
\hline & $(3.46)$ & $(-4.04)$ & $(0.47)$ & $(-1.19)$ \\
\hline Industry-adjusted return & 0.00 & -0.00 & -0.01 & 0.01 \\
\hline & $(0.60)$ & $(-0.18)$ & $(-0.85)$ & $(1.33)$ \\
\hline Constant & $0.53 * * *$ & $0.27 * * *$ & $0.50^{* * *}$ & $0.28 * * *$ \\
\hline & $(9.54)$ & $(5.19)$ & $(5.86)$ & $(3.44)$ \\
\hline Year fixed-effects & Yes & Yes & Yes & Yes \\
\hline Industry fixed-effects & Yes & Yes & Yes & Yes \\
\hline Observations & 3,079 & 3,079 & 1,616 & 1,616 \\
\hline Adjusted R-squared & 0.375 & 0.405 & 0.418 & 0.452 \\
\hline
\end{tabular}


Robust T-statistics in parentheses. *, **, *** indicate significance at $0.10,0.05$, and 0.01 levels using two-tailed tests. See the appendix for variable descriptions. This table shows results of the OLS model using the $\log$ ratio of capital covenants (columns 1 and 3) and the log ratio of performance covenants (columns 2 and 4) as dependent variables of interest. Columns (1) and (2) show results using the full sample, while columns (3) and (4) show results using the restricted sample of loans with non-bank investor participation. Inferences remain unchanged if the number of covenants is used as the dependent variable instead of the covenant ratio. 
Panel B: Effects of dual-holder participation on loan characteristics after controlling for FRQ

\begin{tabular}{|c|c|c|c|c|c|c|}
\hline \multirow{3}{*}{ VARIABLES } & \multirow[t]{2}{*}{ (1) } & \multirow{2}{*}{$\begin{array}{c}(2) \\
\text { Sample }=\text { All }\end{array}$} & \multirow[t]{2}{*}{ (3) } & \multirow{2}{*}{\multicolumn{3}{|c|}{$\begin{array}{l}(4) \\
\text { Sample=Institutional participation }\end{array}$}} \\
\hline & & & & & & \\
\hline & $\begin{array}{c}\text { Log(loan } \\
\text { amount) }\end{array}$ & $\begin{array}{l}\text { Log(loan } \\
\text { maturity) }\end{array}$ & Loan cost & $\begin{array}{l}\text { Log(loan } \\
\text { amount) }\end{array}$ & $\begin{array}{l}\text { Log(loan } \\
\text { maturity) }\end{array}$ & Loan cost \\
\hline \multirow[t]{2}{*}{ Dual-holder } & 0.07 & $-0.05 * *$ & 2.80 & 0.08 & -0.01 & 9.55 \\
\hline & $(1.55)$ & $(-2.07)$ & $(0.56)$ & $(1.42)$ & $(-0.55)$ & $(1.27)$ \\
\hline \multirow[t]{2}{*}{ FRQ } & $1.34 * *$ & 0.55 & $-241.35 * * *$ & $2.67 * *$ & -0.14 & $-407.50 *$ \\
\hline & $(2.38)$ & $(1.53)$ & $(-2.85)$ & $(2.27)$ & $(-0.31)$ & $(-1.89)$ \\
\hline \multirow[t]{2}{*}{ FRQ $\times$ Dual-holder } & -1.52 & $-0.87 *$ & -201.57 & $-2.49 *$ & -0.12 & 95.55 \\
\hline & $(-1.58)$ & $(-1.83)$ & $(-1.58)$ & $(-1.85)$ & $(-0.22)$ & $(0.41)$ \\
\hline \multirow[t]{2}{*}{$\log ($ loan amount $)$} & & & $-8.37 * * *$ & & & $-10.51 * * *$ \\
\hline & & & $(-4.26)$ & & & $(-4.24)$ \\
\hline \multirow[t]{2}{*}{ Log(loan maturity) } & & & $23.60 * * *$ & & & $22.04 * * *$ \\
\hline & & & $(5.47)$ & & & $(3.31)$ \\
\hline \multirow[t]{2}{*}{ Lead-lender reputation } & 0.01 & -0.02 & $-9.16 * *$ & -0.02 & -0.01 & -6.34 \\
\hline & $(0.51)$ & $(-1.30)$ & $(-2.57)$ & $(-0.64)$ & $(-0.70)$ & $(-1.41)$ \\
\hline \multirow[t]{2}{*}{ Lead-lender relation } & $0.10 * * *$ & -0.02 & $-13.34 * * *$ & $0.12 * * *$ & 0.01 & $-20.88 * * *$ \\
\hline & $(3.52)$ & $(-1.14)$ & $(-3.80)$ & $(3.24)$ & $(0.34)$ & $(-4.77)$ \\
\hline \multirow[t]{2}{*}{ Secured $(0 / 1)$} & $-0.16 * * *$ & $0.13 * * *$ & $62.50 * * *$ & $-0.14 * * *$ & $0.12 * * *$ & $63.10 * * *$ \\
\hline & $(-5.16)$ & $(6.89)$ & $(18.77)$ & $(-3.46)$ & $(5.12)$ & $(13.98)$ \\
\hline \multirow[t]{2}{*}{ Revolver (0/1) } & -0.03 & $0.07 * * *$ & $-66.39 * * *$ & $-0.10 * * *$ & $0.11 * * *$ & $-67.10 * * *$ \\
\hline & $(-0.86)$ & $(3.96)$ & $(-15.05)$ & $(-2.58)$ & $(4.90)$ & $(-12.37)$ \\
\hline \multirow[t]{2}{*}{$\operatorname{LBO}(0 / 1)$} & 0.09 & $0.40 * * *$ & $129.76 * * *$ & -0.03 & $0.38 * * *$ & $113.07 * * *$ \\
\hline & $(0.68)$ & $(11.45)$ & $(5.83)$ & $(-0.18)$ & $(10.23)$ & $(4.79)$ \\
\hline \multirow[t]{2}{*}{ M\&A (0/1) } & 0.06 & 0.07 & $22.73 * * *$ & -0.02 & 0.07 & 15.17 \\
\hline & $(0.68)$ & $(1.51)$ & $(2.64)$ & $(-0.14)$ & $(1.22)$ & $(1.20)$ \\
\hline \multirow[t]{2}{*}{$\log ($ Number of lenders $)$} & $0.45 * * *$ & $0.16 * * *$ & $-18.83 * * *$ & $0.38 * * *$ & $0.08 * * *$ & $-35.33 * * *$ \\
\hline & (17.19) & $(9.43)$ & $(-5.22)$ & $(10.02)$ & (3.89) & $(-7.31)$ \\
\hline \multirow[t]{2}{*}{$\log ($ Sales $)$} & $0.36 * * *$ & $-0.05 * * *$ & 1.17 & $0.37 * * *$ & $-0.07 * * *$ & $-5.71 *$ \\
\hline & $(22.62)$ & $(-5.65)$ & $(0.49)$ & $(17.33)$ & $(-5.85)$ & $(-1.88)$ \\
\hline \multirow[t]{2}{*}{ Leverage } & $0.20 * *$ & $0.23 * * *$ & $81.95 * * *$ & 0.12 & $0.25 * * *$ & $58.50 * * *$ \\
\hline & $(2.16)$ & $(5.67)$ & $(6.71)$ & $(0.91)$ & $(5.67)$ & $(3.97)$ \\
\hline \multirow[t]{2}{*}{$\mathrm{BM}$} & $-0.09 * * *$ & 0.03 & $33.75 * * *$ & $-0.12 * *$ & $0.08 * * *$ & $44.21 * * *$ \\
\hline & $(-3.05)$ & $(1.49)$ & $(4.88)$ & $(-2.44)$ & $(3.63)$ & $(4.24)$ \\
\hline Inst. ownership & -0.06 & $0.14 * * *$ & -13.66 & $-0.23 * * *$ & $0.19 * * *$ & $-30.20 * *$ \\
\hline & $(-0.89)$ & $(3.85)$ & $(-1.64)$ & $(-2.63)$ & $(3.89)$ & $(-2.54)$ \\
\hline Z-score & $-0.05 * * *$ & 0.01 & $-5.55 * *$ & $-0.05 * *$ & 0.00 & -2.82 \\
\hline & $(-3.30)$ & $(1.45)$ & $(-2.48)$ & $(-2.16)$ & $(0.88)$ & $(-1.17)$ \\
\hline $\mathrm{S} \& \mathrm{P}$ rated firm $(0 / 1)$ & $0.17 * * *$ & $0.04 * *$ & $19.07 * * *$ & $0.17 * * *$ & -0.00 & $12.23 *$ \\
\hline & $(4.83)$ & $(2.25)$ & (3.86) & $(3.58)$ & $(-0.12)$ & $(1.84)$ \\
\hline$\Delta$ Sales-3yr & $0.09 * * *$ & 0.01 & -1.26 & $0.11 * * *$ & 0.02 & -4.28 \\
\hline & $(3.03)$ & $(0.39)$ & $(-0.37)$ & $(3.05)$ & $(1.38)$ & $(-0.99)$ \\
\hline Illiquidity $\left(* 10^{4}\right)$ & $-0.096 * * *$ & -0.010 & $5.077 * * *$ & $-0.121 * * *$ & $-0.023 * * *$ & $8.365^{* * *}$ \\
\hline & $(-8.09)$ & $(-1.43)$ & $(2.75)$ & $(-6.37)$ & $(-2.82)$ & $(2.72)$ \\
\hline Industry-adjusted return & 0.03 & 0.01 & -1.45 & $0.08 * *$ & -0.01 & 2.83 \\
\hline & $(1.20)$ & $(1.31)$ & $(-0.35)$ & $(1.99)$ & $(-0.92)$ & $(0.46)$ \\
\hline Constant & $2.69 * * *$ & $3.54 * * *$ & $102.66 * * *$ & $2.98 * * *$ & $3.79 * * *$ & $221.58 * * *$ \\
\hline & $(18.56)$ & $(40.46)$ & $(4.38)$ & $(15.07)$ & $(38.51)$ & $(5.84)$ \\
\hline Year fixed-effects & Yes & Yes & Yes & Yes & Yes & Yes \\
\hline Industry fixed-effects & Yes & Yes & Yes & Yes & Yes & Yes \\
\hline Observations & 4,221 & 4,221 & 4,221 & 2,474 & 2,474 & 2,474 \\
\hline Adjusted R-squared & 0.642 & 0.220 & 0.468 & 0.545 & 0.215 & 0.553 \\
\hline
\end{tabular}


Robust T-statistics in parentheses. *, **, *** indicate significance at $0.10,0.05$, and 0.01 levels using two-tailed tests. See the appendix for variable descriptions. This table displays results of the OLS model using loan characteristics as the dependent variable of interest. The loan amount and maturity are included as controls for the loan cost because the cost of a loan is also determined by the loan's maturity and amount. Columns 1-3 show results using the full sample, while columns 4-6 show results using the restricted sample of loans with non-bank investor participation. 
Table 10 - The effect of dual-holders on the borrower

Panel A: Full sample

\begin{tabular}{|c|c|c|c|c|c|c|c|c|c|}
\hline \multirow{3}{*}{ VARIABLES } & \multicolumn{3}{|c|}{ Change in investment } & \multicolumn{3}{|c|}{ Change in financial health } & \multicolumn{3}{|c|}{ Change in operating performance } \\
\hline & (1) & (2) & (3) & $(\overline{4)}$ & $(5)$ & $(6)$ & $(7)$ & $(8)$ & (9) \\
\hline & $\Delta \log$ Assets & $\triangle \operatorname{LogPPE}$ & $\triangle \mathrm{CAPEX}$ & $\Delta$ Debt & $\Delta$ Cash & $\begin{array}{c}\Delta \mathrm{S} / \mathrm{h} \\
\text { Payout }\end{array}$ & $\Delta \mathrm{CFO}$ & $\Delta$ LogSales & $\Delta \mathrm{SGA}$ \\
\hline \multirow[t]{2}{*}{ Dual-holder } & -0.02 & $-0.02 * *$ & 0.00 & -0.06 & -0.00 & $-0.01 * * *$ & -0.00 & $-0.02 *$ & $-0.01 * * *$ \\
\hline & $(-1.51)$ & $(-2.57)$ & $(0.43)$ & $(-1.44)$ & $(-1.19)$ & $(-3.18)$ & $(-1.42)$ & $(-1.65)$ & $(-3.74)$ \\
\hline \multirow[t]{2}{*}{ FRQ } & $-0.42 * *$ & $-0.49 * * *$ & -0.02 & -0.84 & -0.07 & -0.00 & 0.01 & $-0.46 * * *$ & -0.02 \\
\hline & $(-2.30)$ & $(-3.80)$ & $(-0.58)$ & $(-1.22)$ & $(-1.20)$ & $(-0.26)$ & $(0.13)$ & $(-2.63)$ & $(-0.54)$ \\
\hline \multirow[t]{2}{*}{ FRQ $\times$ Dual-holder } & -0.16 & $-0.51 *$ & 0.07 & $-2.80 *$ & -0.14 & $-0.29 * * *$ & $-0.15^{*}$ & -0.34 & $-0.16 * * *$ \\
\hline & $(-0.39)$ & $(-1.90)$ & $(1.33)$ & $(-1.68)$ & $(-1.56)$ & $(-3.37)$ & $(-1.69)$ & $(-1.15)$ & $(-2.83)$ \\
\hline \multirow[t]{2}{*}{ Operating cash flow } & $-0.59 * * *$ & $-0.31 * * *$ & $-0.03 * * *$ & $-1.09 * * *$ & -0.00 & $0.03 *$ & $-0.41 * * *$ & $-0.81 * * *$ & -0.01 \\
\hline & $(-5.63)$ & $(-5.11)$ & $(-2.58)$ & $(-3.91)$ & $(-0.17)$ & (1.94) & $(-9.87)$ & $(-8.75)$ & $(-0.49)$ \\
\hline \multirow[t]{2}{*}{ Leverage ratio } & $0.37 * * *$ & $0.31 * * *$ & $0.02 * *$ & 0.05 & -0.00 & 0.01 & $-0.04 * * *$ & $0.27 * * *$ & $0.03 * * *$ \\
\hline & $(5.18)$ & $(7.72)$ & $(2.29)$ & $(0.36)$ & $(-0.02)$ & $(1.52)$ & $(-2.74)$ & $(6.77)$ & $(3.22)$ \\
\hline \multirow[t]{2}{*}{ Interest expense ratio } & $-7.82 * * *$ & $-5.03 * * *$ & $-0.25 * * *$ & $-7.60 * * *$ & 0.08 & -0.12 & -0.04 & $-5.17 * * *$ & $-0.55 * * *$ \\
\hline & $(-8.78)$ & $(-10.95)$ & $(-2.95)$ & $(-7.03)$ & $(0.63)$ & $(-1.53)$ & $(-0.26)$ & $(-11.11)$ & $(-6.59)$ \\
\hline \multirow{2}{*}{ Net-worth ratio } & -0.05 & 0.03 & 0.00 & $0.33 * * *$ & 0.01 & 0.00 & $-0.03 * * *$ & -0.05 & $0.02 * *$ \\
\hline & $(-1.28)$ & $(1.25)$ & $(0.29)$ & $(2.88)$ & $(1.39)$ & $(0.19)$ & $(-3.74)$ & $(-1.59)$ & $(2.26)$ \\
\hline \multirow[t]{2}{*}{ Current ratio } & 0.00 & 0.00 & 0.00 & 0.03 & $-0.01 * * *$ & -0.00 & -0.00 & -0.00 & $0.00 * *$ \\
\hline & $(0.97)$ & $(0.48)$ & (1.09) & $(1.06)$ & $(-6.15)$ & $(-0.89)$ & $(-0.50)$ & $(-0.06)$ & $(2.04)$ \\
\hline \multirow[t]{2}{*}{ Book-to-market ratio } & $-0.13 * * *$ & $-0.07 * * *$ & $-0.01 * * *$ & $-0.20 * * *$ & $-0.01 * * *$ & $-0.00 * * *$ & $-0.03 * * *$ & $-0.10 * * *$ & $-0.02 * * *$ \\
\hline & $(-7.85)$ & $(-6.70)$ & $(-6.06)$ & $(-4.18)$ & $(-3.45)$ & $(-3.29)$ & $(-6.18)$ & $(-8.99)$ & $(-7.29)$ \\
\hline \multirow[t]{2}{*}{ Constant } & $0.44 * * *$ & $0.28 * * *$ & $0.05 * * *$ & $0.52 * * *$ & $0.01 *$ & 0.00 & $0.12 * * *$ & $0.41 * * *$ & $0.02 * *$ \\
\hline & (10.16) & $(9.81)$ & $(8.32)$ & (4.31) & (1.69) & $(0.52)$ & $(9.60)$ & $(12.23)$ & $(2.29)$ \\
\hline Year fixed-effects & Yes & Yes & Yes & Yes & Yes & Yes & Yes & Yes & Yes \\
\hline Industry fixed-effects & Yes & Yes & Yes & Yes & Yes & Yes & Yes & Yes & Yes \\
\hline Observations & 5,612 & 5,607 & 5,612 & 5,298 & 5,610 & 5,612 & 5,612 & 5,609 & 5,612 \\
\hline Adjusted R-squared & 0.202 & 0.184 & 0.093 & 0.090 & 0.035 & 0.023 & 0.205 & 0.260 & 0.118 \\
\hline
\end{tabular}

Robust T-statistics in parentheses. $*, * *, * * *$ indicate significance at $0.10,0.05$, and 0.01 levels using two-tailed tests. See the appendix for

variable descriptions. 
Panel B: Loans with institutional investor participation

\begin{tabular}{|c|c|c|c|c|c|c|c|c|c|}
\hline \multirow[b]{3}{*}{ VARIABLES } & \multicolumn{3}{|c|}{ Change in investment } & \multicolumn{3}{|c|}{ Change in financial health } & \multicolumn{3}{|c|}{ Change in operating performance } \\
\hline & (1) & $(2)$ & (3) & $(\overline{4)}$ & $(5)$ & $(6)$ & (7) & $(8)$ & (9) \\
\hline & $\Delta$ LogAssets & $\Delta \mathrm{LogPPE}$ & $\triangle \mathrm{CAPEX}$ & $\Delta$ Debt & $\Delta$ Cash & $\begin{array}{c}\Delta \mathrm{S} / \mathrm{h} \\
\text { Payout }\end{array}$ & $\Delta \mathrm{CFO}$ & $\Delta$ LogSales & $\Delta \mathrm{SGA}$ \\
\hline \multirow[t]{2}{*}{ Dual-holder } & $-0.05 * * *$ & $-0.04 * * *$ & 0.00 & $-0.09 *$ & -0.00 & $-0.01 * * *$ & 0.00 & -0.01 & $-0.01 * * *$ \\
\hline & $(-3.12)$ & $(-4.05)$ & $(0.41)$ & $(-1.78)$ & $(-0.76)$ & $(-3.43)$ & $(0.48)$ & $(-0.76)$ & $(-3.34)$ \\
\hline \multirow{2}{*}{ FRQ } & -0.07 & -0.16 & 0.03 & -1.37 & -0.13 & 0.02 & -0.08 & $-0.57 *$ & 0.01 \\
\hline & $(-0.22)$ & $(-0.76)$ & $(0.70)$ & $(-1.08)$ & $(-1.14)$ & $(0.93)$ & $(-1.12)$ & $(-1.96)$ & $(0.19)$ \\
\hline \multirow[t]{2}{*}{ FRQ $\times$ Dual-holder } & -0.32 & $-0.77 * *$ & 0.03 & -1.81 & -0.10 & $-0.32 * * *$ & -0.06 & -0.14 & $-0.18 * * *$ \\
\hline & $(-0.70)$ & $(-2.47)$ & $(0.46)$ & $(-0.89)$ & $(-0.75)$ & $(-3.70)$ & $(-0.57)$ & $(-0.37)$ & $(-2.94)$ \\
\hline \multirow{2}{*}{ Operating cash flow } & $-0.60 * * *$ & $-0.36 * * *$ & $-0.04 * *$ & $-0.91 * *$ & $0.04 *$ & 0.03 & $-0.41 * * *$ & $-0.83 * * *$ & -0.01 \\
\hline & $(-3.21)$ & $(-3.22)$ & $(-2.12)$ & $(-2.27)$ & $(1.73)$ & (1.14) & $(-5.98)$ & $(-6.80)$ & $(-0.22)$ \\
\hline \multirow[t]{2}{*}{ Leverage ratio } & $0.43 * * *$ & $0.35 * * *$ & 0.01 & -0.05 & -0.00 & 0.01 & -0.02 & $0.31 * * *$ & $0.02 * * *$ \\
\hline & $(4.07)$ & $(5.81)$ & $(1.21)$ & $(-0.28)$ & $(-0.07)$ & $(1.01)$ & $(-1.22)$ & $(5.77)$ & $(2.62)$ \\
\hline \multirow[t]{2}{*}{ Interest expense ratio } & $-10.09 * * *$ & $-6.71 * * *$ & $-0.25^{* *}$ & $-9.71 * * *$ & 0.08 & -0.13 & $-0.34 * * *$ & $-6.24 * * *$ & $-0.59 * * *$ \\
\hline & $(-8.08)$ & $(-10.84)$ & $(-2.16)$ & $(-6.62)$ & $(1.00)$ & $(-1.02)$ & $(-2.87)$ & $(-10.72)$ & $(-5.57)$ \\
\hline \multirow[t]{2}{*}{ Net worth ratio } & $-0.17 * * *$ & -0.04 & -0.01 & 0.15 & 0.01 & 0.01 & $-0.03 * *$ & $-0.08 * *$ & 0.01 \\
\hline & $(-2.61)$ & $(-0.90)$ & $(-1.03)$ & (1.04) & $(0.57)$ & $(0.56)$ & $(-2.49)$ & $(-2.24)$ & $(1.02)$ \\
\hline \multirow[t]{2}{*}{ Current ratio } & $0.02 * * *$ & $0.01 *$ & 0.00 & 0.06 & $-0.01 * * *$ & $-0.00 *$ & 0.00 & -0.00 & $0.00 * * *$ \\
\hline & $(3.17)$ & $(1.73)$ & $(1.33)$ & $(1.50)$ & $(-3.33)$ & $(-1.73)$ & $(0.51)$ & $(-0.45)$ & $(2.83)$ \\
\hline \multirow[t]{2}{*}{ Book-to-market ratio } & $-0.12 * * *$ & $-0.06 * * *$ & $-0.01 * * *$ & $-0.16^{* *}$ & $-0.01 * * *$ & $-0.00 *$ & $-0.03 * * *$ & $-0.10 * * *$ & $-0.01 * * *$ \\
\hline & $(-5.01)$ & $(-3.96)$ & $(-4.30)$ & $(-2.13)$ & $(-3.47)$ & $(-1.95)$ & $(-4.08)$ & $(-6.25)$ & $(-4.37)$ \\
\hline \multirow[t]{2}{*}{ Constant } & $0.51 * * *$ & $0.34 * * *$ & $0.05 * * *$ & $0.55 * * *$ & 0.00 & 0.00 & $0.10 * * *$ & $0.42 * * *$ & $0.03 * * *$ \\
\hline & $(7.21)$ & $(7.37)$ & $(7.37)$ & $(3.24)$ & $(0.18)$ & $(0.50)$ & $(5.71)$ & $(9.24)$ & $(2.90)$ \\
\hline Year fixed-effects & Yes & Yes & Yes & Yes & Yes & Yes & Yes & Yes & Yes \\
\hline Industry fixed-effects & Yes & Yes & Yes & Yes & Yes & Yes & Yes & Yes & Yes \\
\hline Observations & 3,123 & 3,121 & 3,123 & 3,025 & 3,121 & 3,123 & 3,123 & 3,121 & 3,123 \\
\hline Adjusted R-squared & 0.234 & 0.220 & 0.0907 & 0.123 & 0.0295 & 0.0246 & 0.240 & 0.299 & 0.133 \\
\hline
\end{tabular}


Table 11-IVPROBIT Regression of investors' dual-holding on financial reporting quality

\begin{tabular}{lcc}
\hline & $(1)$ & $(2)$ \\
VARIABLES & Non-bank dual-holding & FRQ \\
\hline
\end{tabular}

\begin{tabular}{|c|c|c|}
\hline $\begin{array}{l}\text { FRQ } \\
\text { Log(non-audit fees) }\end{array}$ & $\begin{array}{c}-25.07 * * \\
(-2.50)\end{array}$ & $\begin{array}{c}-0.0011 * * * \\
(-3.4535)\end{array}$ \\
\hline Secured $(0 / 1)$ & $\begin{array}{l}-0.17 * \\
(-1.72)\end{array}$ & $\begin{array}{c}-0.0078 * * * \\
(-7.1184)\end{array}$ \\
\hline Revolver $(0 / 1)$ & $\begin{array}{l}-0.08 \\
(-1.22)\end{array}$ & $\begin{array}{c}0.0010 \\
(0.9656)\end{array}$ \\
\hline $\operatorname{LBO}(0 / 1)$ & $\begin{array}{l}-0.05 \\
(-0.16)\end{array}$ & $\begin{array}{c}0.0118 * * * \\
(4.3891)\end{array}$ \\
\hline$M \& A(0 / 1)$ & $\begin{array}{l}-0.21 \\
(-0.97)\end{array}$ & $\begin{array}{l}0.0047 * * \\
(2.0332)\end{array}$ \\
\hline Log(number of lenders) & $\begin{array}{c}0.69 * * * \\
(4.59)\end{array}$ & $\begin{array}{c}0.0020 * * \\
(2.4219)\end{array}$ \\
\hline $\log ($ sales $)$ & $\begin{array}{c}0.30 * * * \\
(7.41)\end{array}$ & $\begin{array}{c}0.0034 * * * \\
(5.9689)\end{array}$ \\
\hline Leverage & $\begin{array}{c}0.93 * * * \\
(6.43)\end{array}$ & $\begin{array}{c}0.0147 * * * \\
(4.9022)\end{array}$ \\
\hline Z-score & $\begin{array}{c}-0.04 \\
(-1.21)\end{array}$ & $\begin{array}{c}-0.0020 * * * \\
(-3.7230)\end{array}$ \\
\hline Inst. ownership & $\begin{array}{c}0.23 \\
(1.46)\end{array}$ & $\begin{array}{c}0.0026 \\
(0.6827)\end{array}$ \\
\hline S\&P-rated firm & $\begin{array}{c}0.12 \\
(1.63)\end{array}$ & $\begin{array}{c}0.0009 \\
(0.6319)\end{array}$ \\
\hline$\Delta$ Sales-3yr & $\begin{array}{l}-0.05 \\
(-0.41)\end{array}$ & $\begin{array}{c}-0.0086 * * * \\
(-6.9519)\end{array}$ \\
\hline Illiquidity $\left(* 10^{4}\right)$ & $\begin{array}{c}-118.17 \\
(-0.48)\end{array}$ & $\begin{array}{l}-5.3242 \\
(-1.1722)\end{array}$ \\
\hline Industry-adjusted return & $\begin{array}{c}-0.18 * * * \\
(-2.85)\end{array}$ & $\begin{array}{l}-0.0019 * \\
(-1.6583)\end{array}$ \\
\hline Constant & $\begin{array}{c}-5.18 * * * \\
(-8.81)\end{array}$ & $\begin{array}{c}-0.0403 * * * \\
(-6.1587)\end{array}$ \\
\hline $\begin{array}{l}\text { Observations } \\
\text { Year fixed-effects } \\
\text { Wald } \chi^{2} \text { test of exogeneity }\end{array}$ & $\begin{array}{c}3,407 \\
\text { Yes } \\
1032.87\end{array}$ & $\begin{array}{c}3,407 \\
\text { Yes }\end{array}$ \\
\hline
\end{tabular}

This table presents an analysis of the relation between investors' dual-holding and the financial reporting quality of the firm using an ivprobit regressions. The first stage models the financial reporting quality measure using lagged non-audit fees and the second-stage measures investors' dual-holding. *, **, *** indicate significance at the $0.10,0.05$, and 0.01 levels, respectively, using two-tailed tests. See Appendix for variable definitions 


\begin{tabular}{|c|c|}
\hline VARIABLES & $\begin{array}{c}(1) \\
\text { Loan cost }\end{array}$ \\
\hline Dual-holder & $\begin{array}{c}313.06^{*} \\
(1.83)\end{array}$ \\
\hline FRQ & $\begin{array}{c}-134.51 \\
(-1.06)\end{array}$ \\
\hline Log(loan amount) & $\begin{array}{c}-16.61 * * * \\
(-3.31)\end{array}$ \\
\hline Log(loan maturity) & $\begin{array}{c}28.30 * * * \\
(4.23)\end{array}$ \\
\hline Lead-lender reputation & $\begin{array}{c}0.28 \\
(0.04)\end{array}$ \\
\hline Lead-lender relation & $\begin{array}{l}-5.05 \\
(-0.67)\end{array}$ \\
\hline Secured $(0 / 1)$ & $\begin{array}{c}68.56^{* * *} \\
(9.88)\end{array}$ \\
\hline Revolver $(0 / 1)$ & $\begin{array}{c}-64.40 * * * \\
(-9.64)\end{array}$ \\
\hline LBO $(0 / 1)$ & $\begin{array}{c}177.31 * * * \\
(4.59)\end{array}$ \\
\hline$M \& A(0 / 1)$ & $\begin{array}{c}31.11^{* *} \\
(2.24)\end{array}$ \\
\hline $\log$ (Number of lenders) & $\begin{array}{c}-75.39 * * \\
(-2.30)\end{array}$ \\
\hline Log(Sales) & $\begin{array}{c}-13.06^{*} \\
(-1.69)\end{array}$ \\
\hline Leverage & $\begin{array}{c}56.32 * * \\
(2.17)\end{array}$ \\
\hline BM & $\begin{array}{c}40.81 * * * \\
(5.43)\end{array}$ \\
\hline Inst. ownership & $\begin{array}{c}-6.87 \\
(-0.41)\end{array}$ \\
\hline Z-score & $\begin{array}{l}-1.27 \\
(-0.45)\end{array}$ \\
\hline $\mathrm{S} \& \mathrm{P}$ rated firm $(0 / 1)$ & $\begin{array}{c}8.38 \\
(0.99)\end{array}$ \\
\hline$\Delta$ Sales-3yr & $\begin{array}{l}-11.91 \\
(-1.52)\end{array}$ \\
\hline Industry-adjusted return & $\begin{array}{c}2.98 \\
(0.48)\end{array}$ \\
\hline Constant & $\begin{array}{c}280.21 * * * \\
(3.29)\end{array}$ \\
\hline $\begin{array}{l}\text { Observations } \\
\text { Year fixed-effects } \\
\text { Industry fixed-effects } \\
\text { Wald } \chi^{2} \text { test of exogeneity }\end{array}$ & $\begin{array}{c}3,719 \\
\text { Yes } \\
\text { Yes } \\
1246.55\end{array}$ \\
\hline
\end{tabular}


This table presents an analysis of the relation between investors' dual-holding and the loan cost using 2SLS regressions. The first stage models the investors' dual-holding using liquidity as the instrument and the second-stage measure models the cost of the loan. ${ }^{*}, * *, * * *$ indicate significance at the $0.10,0.05$, and 0.01 levels, respectively, using two-tailed tests. The partial F-statistic and partial R 2 correspond to the first-stage regression. See Appendix for variable definitions. 
Table 13- Determinants of non-bank versus bank investors' dual-holding*

\begin{tabular}{|c|c|c|c|c|}
\hline \multirow[b]{3}{*}{ VARIABLES } & \multirow{2}{*}{\multicolumn{2}{|c|}{ Sample=All }} & \multirow{2}{*}{\multicolumn{2}{|c|}{$\begin{array}{cc}(3) & (4) \\
\text { Sample=Institutional participation }\end{array}$}} \\
\hline & & & & \\
\hline & $\begin{array}{c}\text { Non-bank dual- } \\
\text { holding }\end{array}$ & Bank dual-holding & $\begin{array}{l}\text { Non-bank dual- } \\
\text { holding }\end{array}$ & Bank dual-holding \\
\hline FRQ & $\begin{array}{l}-1.94 * \\
(-1.77)\end{array}$ & $\begin{array}{l}-1.05 \\
(-1.11)\end{array}$ & $\begin{array}{l}-1.49 \\
(-1.10)\end{array}$ & $\begin{array}{c}-0.91 \\
(-0.59)\end{array}$ \\
\hline Secured $(0 / 1)$ & $\begin{array}{l}-0.01 \\
(-0.13)\end{array}$ & $\begin{array}{c}-0.51 * * * \\
(-6.38)\end{array}$ & $\begin{array}{l}-0.20 * * \\
(-2.47)\end{array}$ & $\begin{array}{c}-0.85 * * * \\
(-5.87)\end{array}$ \\
\hline Revolver $(0 / 1)$ & $\begin{array}{l}-0.09 \\
(-1.41)\end{array}$ & $\begin{array}{l}0.14 * * \\
(2.09)\end{array}$ & $\begin{array}{l}-0.05 \\
(-0.76)\end{array}$ & $\begin{array}{l}0.23 * * \\
(2.52)\end{array}$ \\
\hline $\operatorname{LBO}(0 / 1)$ & $\begin{array}{c}-1.49 * * * \\
(-3.00)\end{array}$ & $\begin{array}{c}-3.34 * * * \\
(-7.38)\end{array}$ & $\begin{array}{c}-1.77 * * * \\
(-3.86)\end{array}$ & - \\
\hline$M \& A(0 / 1)$ & $\begin{array}{l}-0.12 \\
(-0.71)\end{array}$ & $\begin{array}{l}-0.14 \\
(-0.88)\end{array}$ & $\begin{array}{l}-0.09 \\
(-0.46)\end{array}$ & $\begin{array}{l}-0.32 \\
(-1.33)\end{array}$ \\
\hline $\log ($ number of lenders) & $\begin{array}{l}0.84 * * * \\
(16.22)\end{array}$ & $\begin{array}{l}1.08 * * * \\
(19.70)\end{array}$ & $\begin{array}{c}0.42 * * * \\
(6.92)\end{array}$ & $\begin{array}{l}1.40^{* * * *} \\
(14.22)\end{array}$ \\
\hline $\log$ (sales) & $\begin{array}{c}0.26 * * * \\
(8.37)\end{array}$ & $\begin{array}{c}0.15 * * * \\
(4.47)\end{array}$ & $\begin{array}{c}0.29 * * * \\
(7.83)\end{array}$ & $\begin{array}{c}0.21 * * * \\
(3.97)\end{array}$ \\
\hline Leverage & $\begin{array}{c}0.62 * * * \\
(3.42)\end{array}$ & $\begin{array}{l}-0.34 * * \\
(-2.03)\end{array}$ & $\begin{array}{c}0.61 * * * \\
(3.05)\end{array}$ & $\begin{array}{l}-0.23 \\
(-0.93)\end{array}$ \\
\hline $\mathrm{BM}$ & $\begin{array}{l}-0.20 * * \\
(-2.54)\end{array}$ & $\begin{array}{l}-0.16^{* *} \\
(-2.55)\end{array}$ & $\begin{array}{c}-0.22 * * * \\
(-2.76)\end{array}$ & $\begin{array}{l}-0.16 \\
(-1.57)\end{array}$ \\
\hline Inst. ownership & $\begin{array}{l}0.05 \\
(0.35)\end{array}$ & $\begin{array}{c}0.54 * * * * \\
(3.31)\end{array}$ & $\begin{array}{c}0.14 \\
(0.75)\end{array}$ & $\begin{array}{c}1.03 * * * \\
(3.91)\end{array}$ \\
\hline Z-score & $\begin{array}{c}-0.06^{* * *} \\
(-2.20)\end{array}$ & $\begin{array}{c}-0.05^{* *} \\
(-2.27)\end{array}$ & $\begin{array}{l}-0.04 \\
(-1.53)\end{array}$ & $\begin{array}{c}-0.11 * * * \\
(-2.96)\end{array}$ \\
\hline S\&P-rated firm & $\begin{array}{c}0.25 * * * \\
(3.20)\end{array}$ & $\begin{array}{c}0.02 \\
(0.32)\end{array}$ & $\begin{array}{c}0.27 * * * \\
(3.05)\end{array}$ & $\begin{array}{c}0.05 \\
(0.45)\end{array}$ \\
\hline$\Delta$ Sales-3yr & $\begin{array}{c}0.18 * * * \\
(2.97)\end{array}$ & $\begin{array}{c}-0.04 \\
(-0.70)\end{array}$ & $\begin{array}{c}0.22 * * * \\
(3.22)\end{array}$ & $\begin{array}{l}-0.01 \\
(-0.12)\end{array}$ \\
\hline Illiquidity $\left(* 10^{4}\right)$ & $\begin{array}{l}0.000 \\
(0.01)\end{array}$ & $\begin{array}{c}-0.112 * * * \\
(-5.52)\end{array}$ & $\begin{array}{l}-0.026 \\
(-0.85)\end{array}$ & $\begin{array}{c}-0.086 * * \\
(-2.46)\end{array}$ \\
\hline Industry-adjusted return & $\begin{array}{c}-0.09 \\
(-1.43)\end{array}$ & $\begin{array}{l}-0.08^{*} \\
(-1.69)\end{array}$ & $\begin{array}{l}-0.09 \\
(-1.23)\end{array}$ & $\begin{array}{c}-0.06 \\
(-0.77)\end{array}$ \\
\hline Constant & $\begin{array}{c}-4.57 * * * \\
(-14.68)\end{array}$ & $\begin{array}{c}-2.14 * * * \\
(-6.89)\end{array}$ & $\begin{array}{c}-3.41 * * * \\
(-9.01)\end{array}$ & $\begin{array}{c}-3.55^{* * * *} \\
(-7.12)\end{array}$ \\
\hline Year fixed-effects & Yes & Yes & Yes & Yes \\
\hline Industry fixed-effects & Yes & Yes & Yes & Yes \\
\hline Observations & 3,719 & 3,719 & 1,972 & 1,920 \\
\hline Pseudo R-squared & 0.298 & 0.435 & 0.218 & 0.478 \\
\hline
\end{tabular}

*Dual-holder is this table is defined as investors that become equity holders in the quarter following lending to the firm.

This table presents the results of the probit model of investors' dual-holding in a facility. Robust zstatistics in parentheses. $*, * *, * * *$ indicate significance at $0.10,0.05$, and 0.01 levels using two-tailed tests. See the appendix for variable descriptions 
Table 14- Changes in bid-ask before and during earnings announcement

\begin{tabular}{|c|c|c|c|c|c|c|c|}
\hline \multirow[t]{2}{*}{ VARIABLES } & \multicolumn{2}{|c|}{$\begin{array}{c}\text { (1) } \\
\text { Non-bank dual-holders }\end{array}$} & \multicolumn{2}{|c|}{$\begin{array}{c}\text { (2) } \\
\text { Bank dual-holders }\end{array}$} & \multicolumn{2}{|c|}{$\begin{array}{c}\text { (3) } \\
\text { Not a dual-holder }\end{array}$} & \multirow[t]{2}{*}{$(3)-(1)$} \\
\hline & Mean & Median & Mean & Median & Mean & Median & \\
\hline$\Delta$ Spread $_{\text {pre-event }}(\%)$ & $\begin{array}{c}1.21 * * * \\
(3.70)\end{array}$ & $\begin{array}{c}-2.36 * * * \\
(-7.60)\end{array}$ & $\begin{array}{l}2.24 * * * \\
(6.79)\end{array}$ & $\begin{array}{c}-1.70 * * * \\
(-4.48)\end{array}$ & $\begin{array}{l}4.73 * * * \\
(19.51)\end{array}$ & $\begin{array}{l}-1.56 \\
(-0.55)\end{array}$ & $\begin{array}{c}3.52 * * * \\
(8.14)\end{array}$ \\
\hline Observations & 11,045 & & 19,875 & & 36,016 & & \\
\hline$\Delta$ Spread $_{\text {event }}(\%)$ & $\begin{array}{c}18.68 * * * \\
(21.84)\end{array}$ & $\begin{array}{l}1.65^{* * *} \\
(15.95)\end{array}$ & $\begin{array}{c}23.21 * * * \\
(32.30)\end{array}$ & $\begin{array}{r}4.76 * * * \\
(29.04)\end{array}$ & $\begin{array}{c}25.42 * * * \\
(47.98)\end{array}$ & $\begin{array}{l}4.47 * * * \\
(38.64)\end{array}$ & $\begin{array}{c}6.73 * * * \\
(7.41)\end{array}$ \\
\hline Observations & 11,045 & & 19,873 & & 36,014 & & \\
\hline
\end{tabular}

The table above displays changes in a firm's bid-ask spread before and during its earnings announcement day. A firm is considered to have a nonbank (bank) dual-holder if it has at least one facility on the announcement date with a non-bank (bank) lender that also holds the firm's shares in that quarter. Robust T-statistics in parentheses for mean values. Median is tested using Wilcoxon signed-rank test with Z-statistic in parenthesis. *, $* *, * * *$ indicate significance at $0.10,0.05$, and 0.01 levels using two-tailed tests. Observations are at firm-quarter level. See the appendix for variable descriptions.

Table 15- Changes in illiquidity before and during earnings announcement

\begin{tabular}{|c|c|c|c|c|c|c|c|}
\hline \multirow[t]{2}{*}{ VARIABLES } & \multicolumn{2}{|c|}{$\begin{array}{c}\text { (1) } \\
\text { Non-bank dual-holders }\end{array}$} & \multicolumn{2}{|c|}{$\begin{array}{c}(2) \\
\text { Bank dual-holders }\end{array}$} & \multicolumn{2}{|c|}{$\begin{array}{c}(3) \\
\text { Not a dual-holder }\end{array}$} & \multirow[t]{2}{*}{$(3)-(1)$} \\
\hline & Mean & Median & Mean & Median & Mean & Median & \\
\hline$\Delta$ Illiquidity ${ }_{\text {pre-event }}(\%)$ & $\begin{array}{l}6.09 * * * \\
(11.18)\end{array}$ & $\begin{array}{c}0.12 * * * \\
(4.80)\end{array}$ & $\begin{array}{l}7.76^{* * * *} \\
(18.82)\end{array}$ & $\begin{array}{c}0.36^{* * * *} \\
(9.81)\end{array}$ & $\begin{array}{c}10.19^{* * * *} \\
(37.28)\end{array}$ & $\begin{array}{l}1.47 * * * \\
(21.03)\end{array}$ & $\begin{array}{c}4.10 * * * \\
(8.47)\end{array}$ \\
\hline Observations & 11,044 & & 19,820 & & 34,750 & & \\
\hline$\Delta$ Illiquidity $_{\text {event }}(\%)$ & $\begin{array}{c}-0.98 * * \\
(-2.39)\end{array}$ & $\begin{array}{c}-11.05 * * * \\
(-11.66)\end{array}$ & $\begin{array}{c}0.68 \\
(1.25) \\
10826\end{array}$ & $\begin{array}{c}-11.19 * * * \\
(-12.71)\end{array}$ & $\begin{array}{c}3.26 * * * \\
(9.32) \\
34874\end{array}$ & $\begin{array}{c}-9.87 * * * \\
(-14.63)\end{array}$ & $\begin{array}{c}4.24 * * * \\
(6.73)\end{array}$ \\
\hline
\end{tabular}

The table above displays changes in a firm's illiquidity before and during its earnings announcement day. A firm is considered to have a non-bank (bank) dual-holder if it has at least one facility on the announcement date with a non-bank (bank) lender that also holds the firm's shares in that quarter. Robust T-statistics in parentheses for mean values. Median is tested using Wilcoxon signed-rank test with Z-statistic in parenthesis. *, **, *** indicate significance at $0.10,0.05$, and 0.01 levels using two-tailed tests. Observations are at firm-quarter level. See the appendix for variable descriptions. 
Table 16- Risk-adjusted cumulated abnormal excess returns using the Fama-French 3-factor model

\begin{tabular}{|c|c|c|c|c|c|c|c|}
\hline \multirow[t]{2}{*}{ VARIABLES } & \multicolumn{2}{|c|}{$\begin{array}{c}\text { (1) } \\
\text { Non-bank dual-holders }\end{array}$} & \multicolumn{2}{|c|}{$\begin{array}{c}(2) \\
\text { Bank dual-holders }\end{array}$} & \multicolumn{2}{|c|}{$\begin{array}{c}\text { (3) } \\
\text { Not a dual-holder }\end{array}$} & \multirow[t]{2}{*}{$(3)-(1)$} \\
\hline & Mean & Median & Mean & Median & Mean & Median & \\
\hline CAR (\%) & $\begin{array}{c}0.05 \\
(0.56)\end{array}$ & $\begin{array}{c}0.04 \\
(0.69)\end{array}$ & $\begin{array}{l}0.21 * * \\
(2.06)\end{array}$ & $\begin{array}{l}0.07 * \\
(1.71)\end{array}$ & $\begin{array}{l}0.35^{* * *} \\
(7.67)\end{array}$ & $\begin{array}{c}0.13 * * * \\
(6.59)\end{array}$ & $\begin{array}{c}0.30 * * * \\
(3.69)\end{array}$ \\
\hline Observations & 11,003 & & 19,811 & & 35,501 & & \\
\hline BHAR (\%) & $\begin{array}{c}0.04 \\
(0.45) \\
11,003\end{array}$ & $\begin{array}{c}0.00 \\
(0.183)\end{array}$ & $\begin{array}{c}0.19 * * \\
(1.85) \\
19,811\end{array}$ & $\begin{array}{c}0.02 \\
(0.96)\end{array}$ & $\begin{array}{c}0.32 * * * \\
(7.03) \\
35,501\end{array}$ & $\begin{array}{c}0.07 * * * \\
(4.86)\end{array}$ & $\begin{array}{c}0.27 * * * \\
(3.41)\end{array}$ \\
\hline
\end{tabular}

The table above displays firms' abnormal returns during the three days surrounding the earnings announcement day. The firm's expected returns are calculated using the Fama-French three-factor model: $r_{i t}=r_{f}+\hat{\alpha}_{1}\left(r_{m t}-r_{f}\right)+\hat{\alpha}_{2} S M B_{t}+\hat{\alpha}_{3} H M L_{t}+\varepsilon_{i t}$. A firm is considered to have a non-bank (bank) dual-holder if it has at least one facility on the announcement date with a non-bank (bank) lender that also holds the firm's shares in that quarter. CAR and BHAR are winsorized at $1 \%$ level. Robust T-statistics in parentheses for mean values. Median is tested using Wilcoxon signed-rank test with Z-statistic in parenthesis. $*, * *, * *$ indicate significance at $0.10,0.05$, and 0.01 levels using two-tailed tests. Observations are at firm-quarter level. See the appendix for variable descriptions 
Table 17-Effect of dual-holders on the firm's equity-price informativeness

\begin{tabular}{|c|c|c|c|c|}
\hline VARIABLES & $\mathrm{E}($ Sign $)$ & $\begin{array}{l}(1) \\
R_{t} \\
\end{array}$ & $\begin{array}{c}(2) \\
\text { Dual Holder }=N C B \\
R_{t}\end{array}$ & $\begin{array}{c}(3) \\
\text { Dual Holder }=C B \\
R_{t} \\
\end{array}$ \\
\hline $\mathrm{EPS}_{\mathrm{t}-1}$ & - & $\begin{array}{c}-0.0155^{* * *} * \\
(-4.74)\end{array}$ & $\begin{array}{c}-0.0128 * * * \\
(-3.82)\end{array}$ & $\begin{array}{c}-0.0122 * * * \\
(-3.54)\end{array}$ \\
\hline $\mathrm{EPS}_{\mathrm{t}}$ & + & $\begin{array}{c}0.0113 * * * \\
(3.54)\end{array}$ & $\begin{array}{c}0.0122 * * * \\
(3.75)\end{array}$ & $\begin{array}{c}0.0063^{*} \\
(1.87)\end{array}$ \\
\hline $\mathrm{EPS}_{\mathrm{t} 3}$ & + & $\begin{array}{c}0.0063 * * * \\
(7.70)\end{array}$ & $\begin{array}{c}0.0048 * * * \\
(5.68)\end{array}$ & $\begin{array}{c}0.0089 * * * \\
(7.47)\end{array}$ \\
\hline $\mathrm{R}_{\mathrm{t} 3}$ & - & $\begin{array}{c}-0.1375^{* * *} * \\
(-56.81)\end{array}$ & $\begin{array}{c}-0.1369 * * * \\
(-53.26)\end{array}$ & $\begin{array}{c}-0.1297 * * * \\
(-44.10)\end{array}$ \\
\hline Dual Holder & & & $\begin{array}{c}-0.0120 * * * \\
(-3.07)\end{array}$ & $\begin{array}{c}-0.0128 * * * \\
(-4.14)\end{array}$ \\
\hline Dual Holder $\times \mathrm{EPS}_{\mathrm{t}-1}$ & & & $\begin{array}{c}-0.0506 * * * \\
(-3.05)\end{array}$ & $\begin{array}{c}-0.0537 * * * \\
(-4.27)\end{array}$ \\
\hline Dual Holder $\times \mathrm{EPS}_{\mathrm{t}}$ & & & $\begin{array}{c}-0.0175 \\
(-1.05)\end{array}$ & $\begin{array}{c}0.0243^{* *} \\
(1.99)\end{array}$ \\
\hline Dual Holder $\times \mathrm{EPS}_{\mathrm{t} 3}$ & & & $\begin{array}{c}0.0373 * * * \\
(8.90)\end{array}$ & $\begin{array}{c}-0.0040 * * \\
(-2.30)\end{array}$ \\
\hline Dual Holder $\times R_{t 3}$ & & & $\begin{array}{c}-0.0125^{*} \\
(-1.87)\end{array}$ & $\begin{array}{c}-0.0242^{* * * *} \\
(-5.15)\end{array}$ \\
\hline Constant & & $\begin{array}{c}0.0569 * * * \\
(14.48)\end{array}$ & $\begin{array}{c}0.0569 * * * \\
(14.49)\end{array}$ & $\begin{array}{c}0.0558 * * * \\
(14.20)\end{array}$ \\
\hline Observations & & 56,869 & 56,869 & 56,869 \\
\hline Number of firms & & 1,985 & 1,985 & 1,985 \\
\hline Year fixed-effects & & Yes & Yes & Yes \\
\hline R-squared & & 0.125 & 0.126 & 0.126 \\
\hline
\end{tabular}

This table presents the results of fixed effect model FERC regressions on firm-year panel data. Including year fixed-effects transforms the model into a two-way fixed-effect model. F-statistic suggests that a pooled regression model is inappropriate. T-statistics in parentheses. Column (1) presents the original FERC model. Dual Holder equals 1 for firm-quarters with non-commercial bank dual-holders in column (2) and commercial bank dual-holders in column (3).*,**,*** indicate significance at 0.10 , 0.05 , and 0.01 levels using two-tailed tests. See appendix for the variables' descriptions. 
Table 18- Effect of dual-holders on the bid-ask spread

Panel A: Effect of dual-holders on the bid-ask spread

\begin{tabular}{|c|c|c|}
\hline VARIABLES & $\begin{array}{c}(1) \\
\Delta \text { Spread }_{\text {pre-event }}(\%)\end{array}$ & $\begin{array}{c}(2) \\
\Delta \text { Spread }_{\text {event }}(\%)\end{array}$ \\
\hline NCB Dual Holder & $\begin{array}{l}-0.0028 \\
(-0.55)\end{array}$ & $\begin{array}{c}-0.0707^{* * * *} \\
(-2.73)\end{array}$ \\
\hline CB Dual Holder & $\begin{array}{l}-0.0058 \\
(-1.04)\end{array}$ & $\begin{array}{c}-0.0126 \\
(-0.83)\end{array}$ \\
\hline NCB Participation & $\begin{array}{c}-0.0052 \\
(-1.08)\end{array}$ & $\begin{array}{c}0.0201 \\
(0.86)\end{array}$ \\
\hline CB Participation & $\begin{array}{c}0.0160^{* * *} \\
(2.51)\end{array}$ & $\begin{array}{c}0.0283^{*} \\
(1.68)\end{array}$ \\
\hline Size & $\begin{array}{c}0.0022 \\
(1.22)\end{array}$ & $\begin{array}{c}0.0160 * * * \\
(3.67)\end{array}$ \\
\hline BtM & $\begin{array}{c}-0.0122 * * * \\
(-3.04)\end{array}$ & $\begin{array}{c}-0.0588^{* * * *} \\
(-4.59)\end{array}$ \\
\hline ROA & $\begin{array}{c}-0.0211 \\
(-0.78)\end{array}$ & $\begin{array}{r}-0.1490 \\
(-1.41)\end{array}$ \\
\hline Loss Firm & $\begin{array}{l}0.0054 \\
(1.14)\end{array}$ & $\begin{array}{r}-0.0117 \\
(-1.01)\end{array}$ \\
\hline Number of Analysts & $\begin{array}{c}-0.0102 * * \\
(-2.48)\end{array}$ & $\begin{array}{c}-0.0240^{* * * *} \\
(-2.65)\end{array}$ \\
\hline Z score & $\begin{array}{l}0.0015 \\
(1.61)\end{array}$ & $\begin{array}{l}0.0100 \\
(1.53)\end{array}$ \\
\hline Illiquidity & $\begin{array}{c}0.2177^{* * * *} \\
(6.05)\end{array}$ & $\begin{array}{c}0.1215^{*} \\
(1.72)\end{array}$ \\
\hline Constant & $\begin{array}{c}0.0730^{* * * *} \\
(5.89)\end{array}$ & $\begin{array}{c}0.2520^{* * * *} \\
(7.77)\end{array}$ \\
\hline Observations & 48,420 & 48,418 \\
\hline Number of firms & 1,714 & 1,714 \\
\hline Year fixed-effects & Yes & Yes \\
\hline Time-series R-Squared & 0.0120 & 0.00890 \\
\hline Cross-sectional R-Squared & 0.0584 & 0.00908 \\
\hline \multicolumn{3}{|c|}{$\begin{array}{l}\text { This table presents the results of fixed effect panel data regressions using changes in bid-ask spread } \\
\text { during pre-event period (column } 1 \text { ) and event period (column } 2 \text { ) from the spread during a non-event } \\
\text { period. Including year fixed-effects transforms the model into a two-way fixed-effect model. F-statistic } \\
\text { suggests that a pooled regression model is inappropriate. NCB Dual Holder equals } 1 \text { for firm-quarters } \\
\text { with non-commercial bank dual-holders and } 0 \text { otherwise. CB Dual Holder equals } 1 \text { for firm-quarters } \\
\text { with commercial bank dual-holders and } 0 \text { otherwise. T-statistics clustered by firm are in parenthesis. *, } \\
* *, * * * \text { indicate significance at } 0.10,0.05 \text {, and } 0.01 \text { levels using two-tailed tests. See appendix for the } \\
\text { variables' descriptions. }\end{array}$} \\
\hline
\end{tabular}


Panel B: Effect of the number of dual-holders on the bid-ask spread

\begin{tabular}{|c|c|c|}
\hline VARIABLES & $\Delta$ Spread $_{\text {pre-event }}^{(1)}(\%)$ & $\begin{array}{c}(2) \\
\Delta \text { Spread }_{\text {event }}(\%)\end{array}$ \\
\hline NCB Dual Holder & $\begin{array}{c}-0.0030 \\
(-0.50)\end{array}$ & $\begin{array}{c}-0.0689 * * \\
(-2.34)\end{array}$ \\
\hline CB Dual Holder & $\begin{array}{c}-0.0033 \\
(-0.56)\end{array}$ & $\begin{array}{c}-0.0092 \\
(-0.54)\end{array}$ \\
\hline High Number of Dual-holders (NCB) & $\begin{array}{l}0.0325 \\
(0.97)\end{array}$ & $\begin{array}{c}-0.0452 \\
(-1.29) \\
\end{array}$ \\
\hline High Number of Dual-holders (CB) & $\begin{array}{c}-0.0050 \\
(-0.28)\end{array}$ & $\begin{array}{c}-0.0055 \\
(-0.13)\end{array}$ \\
\hline Low Number of Dual-holders (NCB) & $\begin{array}{c}-0.0056 \\
(-0.84)\end{array}$ & $\begin{array}{l}-0.0052 \\
(-0.32)\end{array}$ \\
\hline Low Number of Dual-holders (CB) & $\begin{array}{c}-0.0080 \\
(-1.61)\end{array}$ & $\begin{array}{r}-0.0117 \\
(-0.87)\end{array}$ \\
\hline NCB Participation & $\begin{array}{c}-0.0049 \\
(-1.03)\end{array}$ & $\begin{array}{c}0.0202 \\
(0.87)\end{array}$ \\
\hline CB Participation & $\begin{array}{c}0.0169 * * * \\
(2.62)\end{array}$ & $\begin{array}{c}0.0303 * \\
(1.83)\end{array}$ \\
\hline Size & $\begin{array}{c}0.0018 \\
(1.04)\end{array}$ & $\begin{array}{l}0.0160 * * * \\
(3.66)\end{array}$ \\
\hline BtM & $\begin{array}{c}-0.0123 * * * \\
(-3.06)\end{array}$ & $\begin{array}{c}-0.0584 * * * \\
(-4.58)\end{array}$ \\
\hline ROA & $\begin{array}{c}-0.0209 \\
(-0.78)\end{array}$ & $\begin{array}{c}-0.1483 \\
(-1.41)\end{array}$ \\
\hline Loss Firm & $\begin{array}{c}0.0056 \\
(1.18)\end{array}$ & $\begin{array}{c}-0.0114 \\
(-0.99)\end{array}$ \\
\hline Number of Analysts & $\begin{array}{c}-0.0103^{* *} \\
(-2.49)\end{array}$ & $\begin{array}{c}-0.0243^{* * *} \\
(-2.69)\end{array}$ \\
\hline Z score & $\begin{array}{c}0.0015 \\
(1.61)\end{array}$ & $\begin{array}{c}0.0099 \\
(1.53)\end{array}$ \\
\hline Illiquidity & $\begin{array}{c}0.2152 * * * \\
(5.97)\end{array}$ & $\begin{array}{c}0.1186^{*} \\
(1.69)\end{array}$ \\
\hline Constant & $\begin{array}{l}0.0756^{* * * *} \\
\quad(6.06)\end{array}$ & $\begin{array}{l}0.2522 * * * \\
\quad(7.76)\end{array}$ \\
\hline Observations & 48,420 & 48,418 \\
\hline Number of firms & 1,714 & 1,714 \\
\hline Year fixed-effects & Yes & Yes \\
\hline Time-series R-Squared & 0.0121 & 0.00890 \\
\hline Cross-sectional R-Squared & 0.0590 & 0.00933 \\
\hline
\end{tabular}

This table presents the results of fixed effect panel data regressions using changes in bid-ask spread during pre-event period (column 1) and event period (column 2) from the spread during a non-event period. Including year fixed-effects transforms the model into a two-way fixed-effect model. F-statistic suggests that a pooled regression model is inappropriate. NCB Dual Holder equals 1 for firm-quarters with non-commercial bank dual-holders and 0 otherwise. CB Dual Holder equals 1 for firm-quarters with commercial bank dual-holders and 0 otherwise. T-statistics clustered by firm are in parenthesis. *, $* *$, *** indicate significance at $0.10,0.05$, and 0.01 levels using two-tailed tests. See appendix for the variables' descriptions. 
Table 19- Effect of dual-holders on the stock liquidity

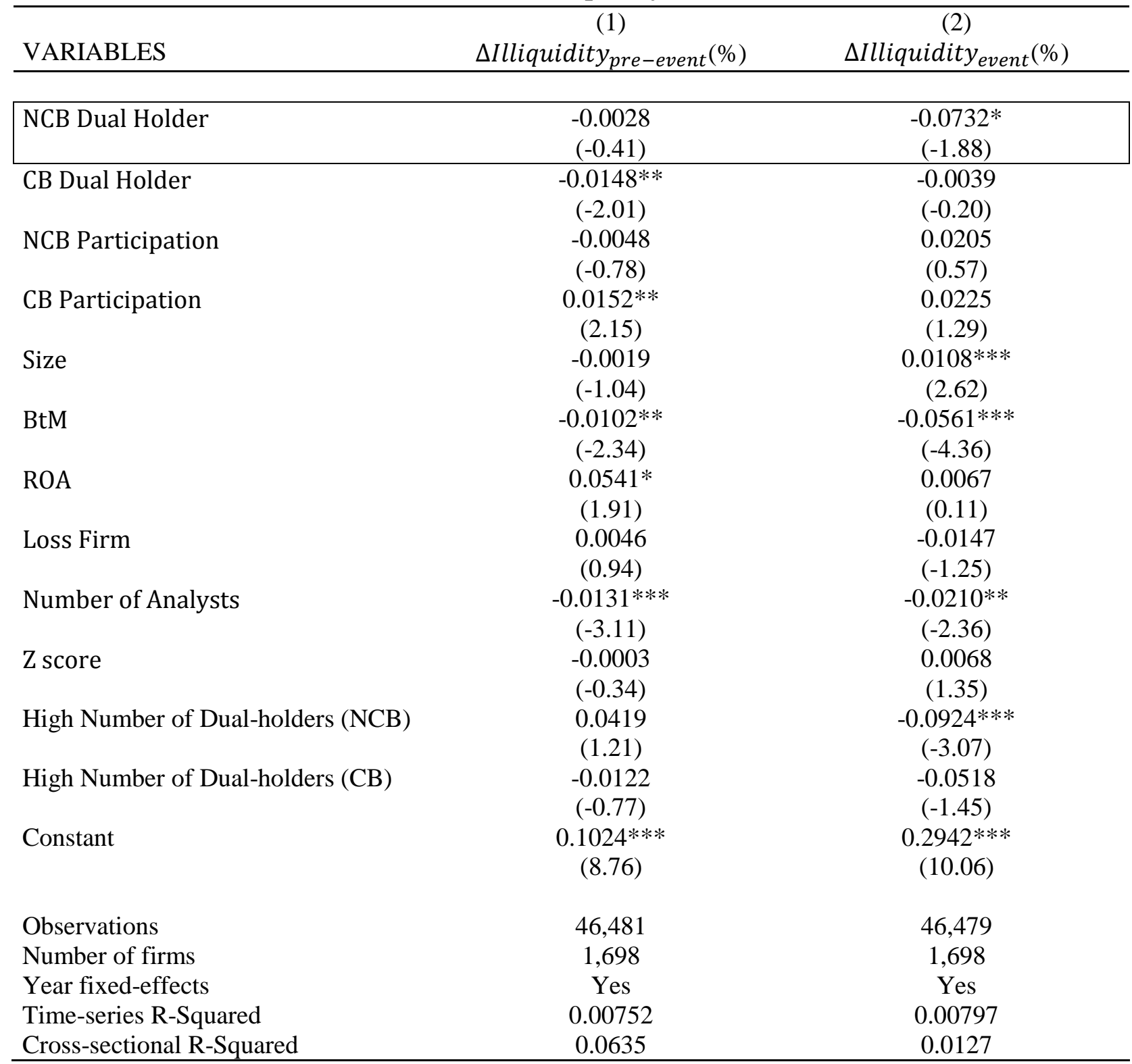

This table presents the results of fixed effect panel data regressions using changes in the firm's stock liquidity during pre-event period (column 1) and event period (column 2) from the liquidity during a nonevent period. Including year fixed-effects transforms the model into a two-way fixed-effect model. Fstatistic suggests that a pooled regression model is inappropriate. T-statistics clustered by firm are in parenthesis. NCB Dual Holder equals 1 for firm-quarters with non-commercial bank dual-holders and 0 otherwise. $C B$ Dual Holder equals 1 for firm-quarters with commercial bank dual-holders and 0 otherwise. *, **, *** indicate significance at $0.10,0.05$, and 0.01 levels using two-tailed tests. See appendix for the variables' descriptions. 
Table 20- Effect of dual-holders on the analyst forecast dispersion

Panel A: Effect of dual-holders on the analyst forecast dispersion

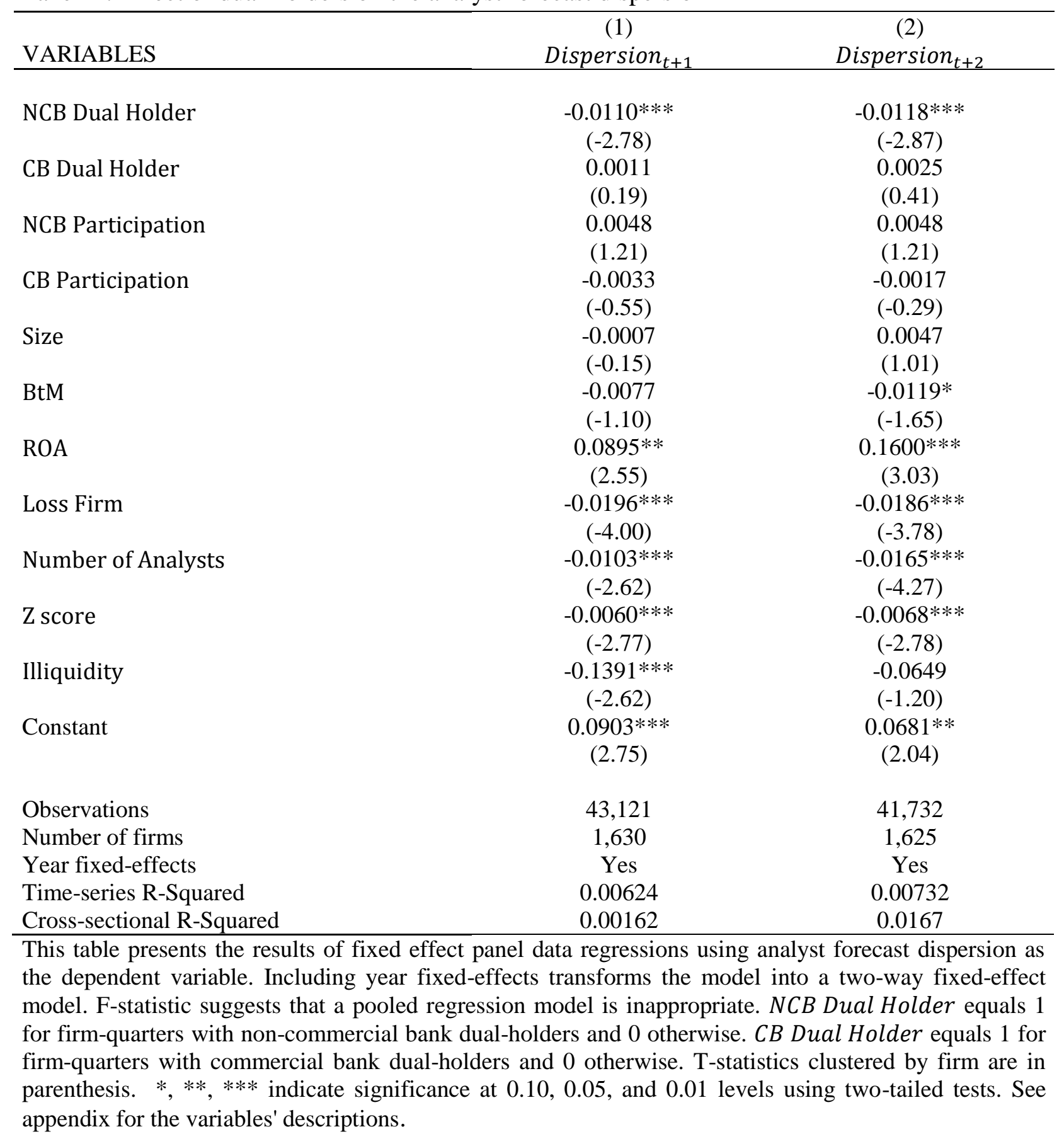


Panel B: Effect of the number of dual-holders on the analyst forecast dispersion

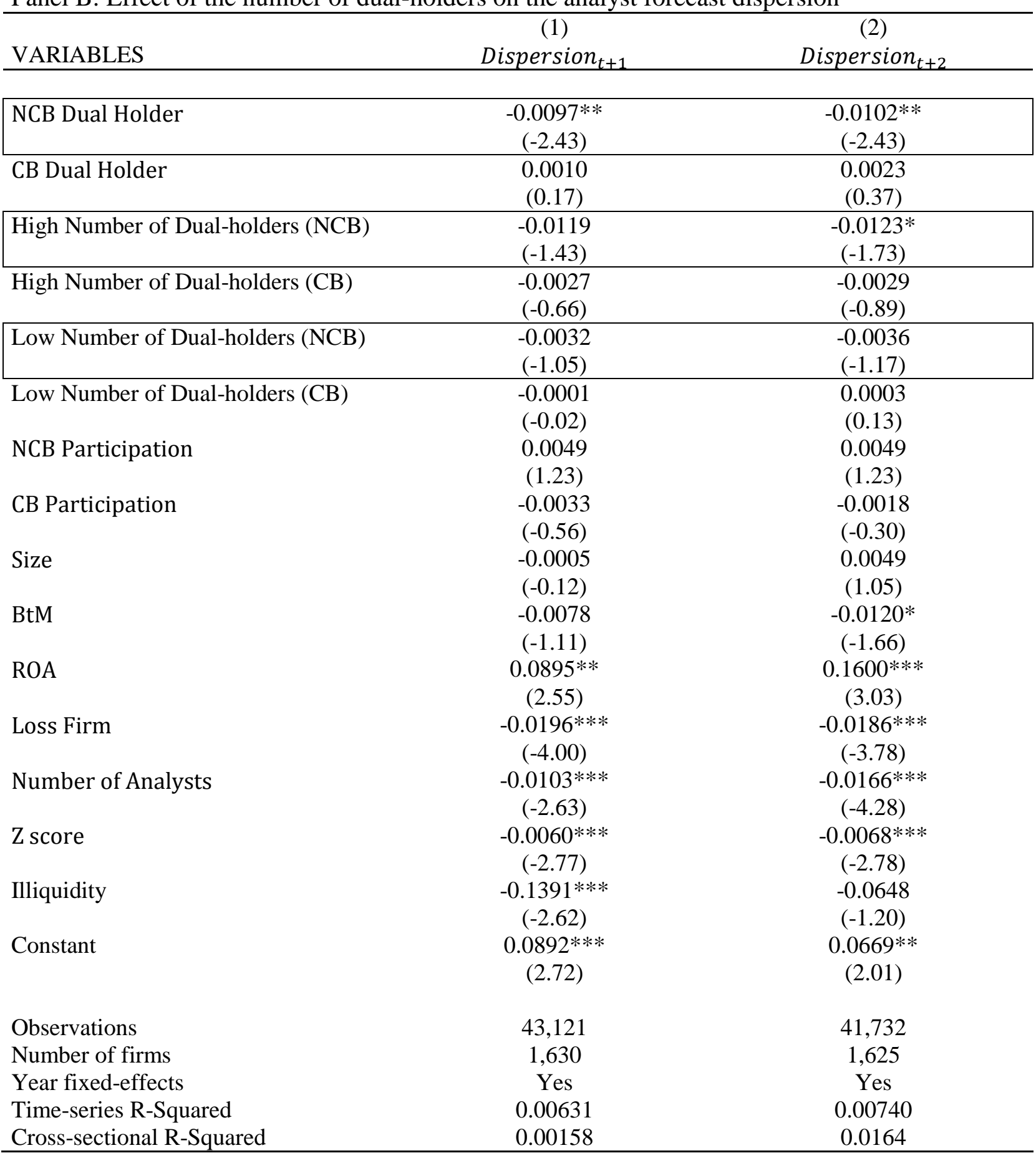

This table presents the results of fixed effect panel data regressions using analyst forecast dispersion as the dependent variable. Including year fixed-effects transforms the model into a two-way fixed-effect model. F-statistic suggests that a pooled regression model is inappropriate. NCB Dual Holder equals 1 for firm-quarters with non-commercial bank dual-holders and 0 otherwise. CB Dual Holder equals 1 for firm-quarters with commercial bank dual-holders and 0 otherwise. T-statistics clustered by firm are in parenthesis. $* * *, * * *$ indicate significance at $0.10,0.05$, and 0.01 levels using two-tailed tests. See appendix for the variables' descriptions. 
Table 21- Effect of dual-holders on abnormal returns

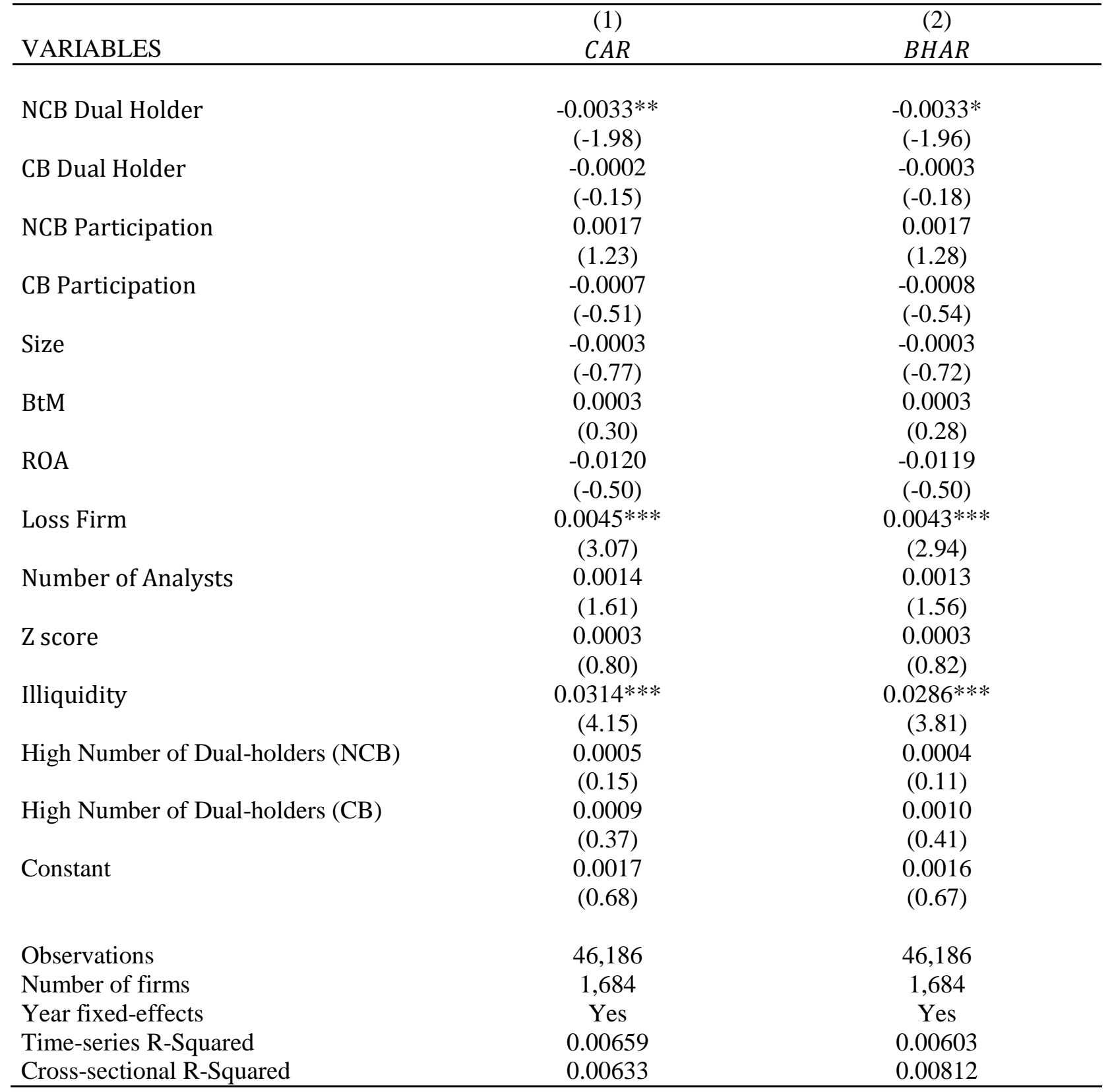

This table presents the results of fixed effect panel data regression using the firm's abnormal returns during the 3-day period surrounding the earnings announcement date as the dependent variable. Including year fixed-effects transforms the model into a two-way fixed-effect model. F-statistic suggests that a pooled regression model is inappropriate. T-statistics clustered by firm are in parenthesis. NCB Dual Holder equals 1 for firm-quarters with non-commercial bank dual-holders and 0 otherwise. CB Dual Holder equals 1 for firm-quarters with commercial bank dual-holders and 0 otherwise. *, **, *** indicate significance at $0.10,0.05$, and 0.01 levels using two-tailed tests. See appendix for the variables' descriptions. 
Table 22- Effect of dual-holding on the likelihood of issuance of earnings forecast

\begin{tabular}{|c|c|c|c|}
\hline VARIABLES & $\begin{array}{c}(1) \\
\text { Forecast }_{t+1}\end{array}$ & $\begin{array}{c}(2) \\
\text { Forecast }_{t+2}\end{array}$ & $\begin{array}{c}\text { (3) } \\
\text { Forecast }_{t+3}\end{array}$ \\
\hline NCB Dual Holder & $\begin{array}{c}1.8551^{*} \\
(1.78)\end{array}$ & $\begin{array}{c}2.7344 * * \\
(2.06)\end{array}$ & $\begin{array}{l}0.5955 \\
(0.58)\end{array}$ \\
\hline CB Dual Holder & $\begin{array}{l}0.2943 \\
(0.13)\end{array}$ & $\begin{array}{c}3.4510 \\
(1.53)\end{array}$ & $\begin{array}{l}-1.6823 \\
(-1.03)\end{array}$ \\
\hline NCB Participation & $\begin{array}{l}-0.5877 \\
(-0.57)\end{array}$ & $\begin{array}{c}-1.2647 \\
(-1.00)\end{array}$ & $\begin{array}{c}-0.8192 \\
(-0.80)\end{array}$ \\
\hline CB Participation & $\begin{array}{c}-0.4338 \\
(-0.19)\end{array}$ & $\begin{array}{c}-2.3920 \\
(-1.03)\end{array}$ & $\begin{array}{l}1.3983 \\
(0.85)\end{array}$ \\
\hline Size & $\begin{array}{l}-1.1924 \\
(-0.98)\end{array}$ & $\begin{array}{l}0.3006 \\
(0.27)\end{array}$ & $\begin{array}{c}-2.9203 \\
(-1.54)\end{array}$ \\
\hline BtM & $\begin{array}{l}-1.7650 \\
(-1.44)\end{array}$ & $\begin{array}{c}-4.7044 * * \\
(-2.19)\end{array}$ & $\begin{array}{l}-0.3878 \\
(-0.20)\end{array}$ \\
\hline ROA & $\begin{array}{l}8.3840 \\
(0.58)\end{array}$ & $\begin{array}{c}17.7473^{*} \\
(1.93)\end{array}$ & $\begin{array}{c}12.1387 \\
(0.63)\end{array}$ \\
\hline Loss Firm & $\begin{array}{c}-0.2013 \\
(-0.24)\end{array}$ & $\begin{array}{c}0.8895 \\
(0.95)\end{array}$ & $\begin{array}{c}-0.2365 \\
(-0.25)\end{array}$ \\
\hline Number of Analysts & $\begin{array}{l}0.0227 \\
(0.03)\end{array}$ & $\begin{array}{c}0.8522 \\
(0.94)\end{array}$ & $\begin{array}{c}0.0412 \\
(0.03)\end{array}$ \\
\hline Z score & $\begin{array}{c}1.2717^{*} \\
(1.90)\end{array}$ & $\begin{array}{r}-1.0941 \\
(-1.57)\end{array}$ & $\begin{array}{l}0.2734 \\
(0.25)\end{array}$ \\
\hline Illiquidity & $\begin{array}{l}9.6818 \\
(0.66)\end{array}$ & $\begin{array}{c}-38.3690 \\
(-1.62)\end{array}$ & $\begin{array}{c}-0.3666 \\
(-0.02)\end{array}$ \\
\hline High Number of Dual-holders (NCB) & $\begin{array}{c}-0.9581 \\
(-0.14)\end{array}$ & $\begin{array}{c}-14.4783 \\
(-0.00)\end{array}$ & $\begin{array}{c}-14.9099 \\
(-0.01)\end{array}$ \\
\hline High Number of Dual-holders (CB) & $\begin{array}{l}1.3822 \\
(0.66)\end{array}$ & $\begin{array}{l}0.0751 \\
(0.03)\end{array}$ & $\begin{array}{l}1.6601 \\
(0.93)\end{array}$ \\
\hline $\begin{array}{l}\text { Observations } \\
\text { Number of firms } \\
\text { Year fixed-effects } \\
\text { Pseudo R-squared }\end{array}$ & $\begin{array}{c}271 \\
111 \\
\text { Yes } \\
0.559\end{array}$ & $\begin{array}{c}197 \\
81 \\
\text { Yes } \\
0.518\end{array}$ & $\begin{array}{c}187 \\
78 \\
\text { Yes } \\
0.453\end{array}$ \\
\hline
\end{tabular}

This table presents the results of a logit fixed effect panel data regressions using instances of managements' issuance of earnings forecast as the dependent variable. Forecast ${ }_{t+1}$ equals 1 if the manager issues an earnings forecast in the next quarter and 0 otherwise. Including year fixed-effects transforms the model into a two-way fixed-effect model. F-statistic suggests that a pooled regression model is inappropriate. T-statistics in parentheses. NCB Dual Holder equals 1 for firm-quarters with non-commercial bank dual-holders and 0 otherwise. CB Dual Holder equals 1 for firm-quarters with commercial bank dual-holders and 0 otherwise. *, **, *** indicate significance at $0.10,0.05$, and 0.01 levels using two-tailed tests. See appendix for the variables' descriptions. 